\title{
REDISEÑANDO MUNDOS
}

\section{Tesis de Maestría}

\section{PLANGESCO}

Autora: Lucía Sandoval Andrade

Director: Germán Retola
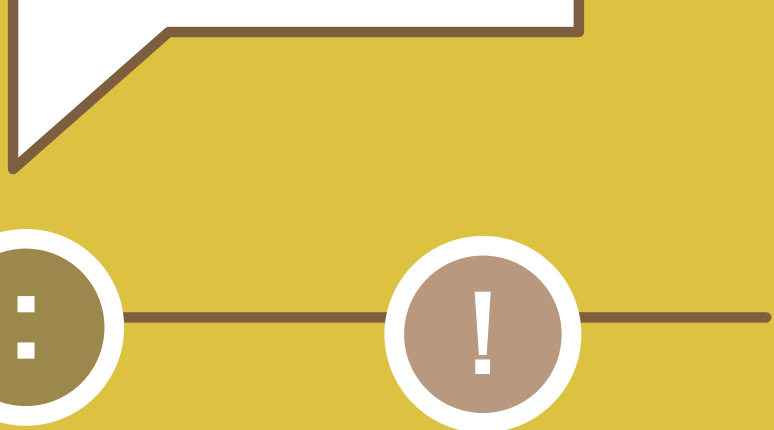
Soy diseñadora gráfica egresada de la

Universidad Nacional de Colombia (2002).

En esta tesis hice el descubrimiento personal a partir de los estudios de Verónica Devalle, de que la manera de historizar el diseño a partir de relatar la historia de los objetos producidos por el mismo, es una de las principales causas de que aún hoy en día lo importante en la práctica del DG sea el objeto final y no el proceso. La historia del DG ha sido la historia de los objetos que produce, no de lo que en esencia es, por ello si no se considera al DG como creador de cultura, la misma manera de verlo ligado a la producción de objetos impide mirar lo que para una sociedad significa su práctica.

El diseño gráfico puede abordarse como oficio o como saber.

Es necesario alejarse de los 'mesianismos' que a veces se le atribuyen al DG como salvador del mundo. Todo profesional es responsable sobre las consecuencias de su trabajo sea cual sea su disciplina. Sin embargo en esta tesis resalto la responsabilidad de el/la diseñador/a gráfico/a desde el punto de vista de la comunicación como diálogo para crear sentidos y, desde allí, tener presente que el Diseño antes de persuadir, puede problematizar situaciones en sus receptores. Sí puede ser agente de cambio de realidades, desde quienes toman consciencia de la responsabilidad de su profesión hacia quienes como usuarios o público receptor sienten y ven la necesidad de transformarse.

Creo que nada es obvio. Por eso me planteo como algo necesario reflexionar sobre la responsabilidad de la práctica de la profesión del DG. Esa responsabilidad no es algo intrínseco a ella, no es algo natural ni algo que los/las profesionales en general analicemos o en lo que concordemos, por lo mismo creo importante generar esa reflexión desde diferentes espacios.

Es algo que quise lograr con el desarrollo de esta tesis, abrir un lugar de pensamiento sobre un aspecto que atraviesa la profesión entera y que pocas veces no detenemos a pensar. 


\section{REDISEÑANDO MUNDOS}

Tesis de maestría PLANGESCO

Lucía Sandoval Andrade 



\section{Agradecimientos}

En el camino de construcción de esta tesis, tuve la fortuna de contar con el apoyo y colaboración de personas invaluables que agradezco día a día haber conocido y sobre todo, permanecer cerca:

Mi familia, siempre

Fernando, puro amor

Iovanna, Tere y Lina, las mejores amigas

Fredy, a quien seguiré llamando maestro

Fontana+Franco, espacio de aprendizajes diarios

Mi director de tesis, Germán Retola, quien desde cuando esto era apenas una idea, escuchó mis intereses, los entendió, me ayudó a darles forma y me guio con la mayor claridad, sensatez, sabiduría y, además, con la mejor energía. 



\section{REDISEÑANDO MUNDOS Tesis de maestría}

Estudio comparativo de la presencia del Diseño con Consciencia Social en los planes curriculares vigentes en 2015, de las carreras de Diseño Gráfico de dos universidades públicas de América Latina: Universidad de Buenos Aires Universidad Nacional de Colombia

Alumna: Lucía Sandoval Andrade Director: Germán Retola

Maestría en Planificación y Gestión de Procesos Comunicacionales PLANGESCO

Facultad de Periodismo

y Comunicación Social

UNIVERSIDAD NACIONAL DE LA PLATA

Argentina, Marzo de 2016 


\section{1. ¿ CÓMO LLEGUÉ AQUÚ Y POR QUÉ ME QUEDÉ?}

1.1. Mi problema, mi oportunidad

2. RED DE CONCEPTOS

2.1. La imagen, ipara qué?

2.2. Una historia de los objetos

de diseño gráfico

2.3 Puntos de referencia en

la historia conocida

2.4 Latinoamérica y el oficio gráfico

2.5 Diseño para la transformación

3. DISEÑO GRÁFICO CON

CONSCIENCIA SOCIAL:

Cultural, político, democrático,

responsable, participativo y económico

3.1. Diseño gráfico, práctica cultural

3.2. La dimensión socio-política

del diseño gráfico

3.3. Con consciencia social

y también económico

3.4 Mirada a las prácticas actuales

3.4.1 Panorámica mundial 


\section{CONIENIDO}

3.4.2 En América Latina,

¿Cómo se está trabajando?

Desde la sociedad civil

Desde la empresa privada

Desde las políticas públicas

Desde la universidad

pública latinoamericana

4. PRESENGIA DEL DISEÑO GRÁFICO CON CONSCIENCIA SOCIAL-

CASOS ELEGIDOS

4.1 Puntos clave en su historia

4.2 Planes curriculares vigentes en 2015

5. MI PLANTEAMIENTO, MI CONCLUSIÓN 99

6. PROPUESTA DE SEMINARIO UNIVERSITARIO

6.1 A quién va dirigido

6.2 Objetivo general

6.3 Metodología general

BIBLIOGRAFíA 


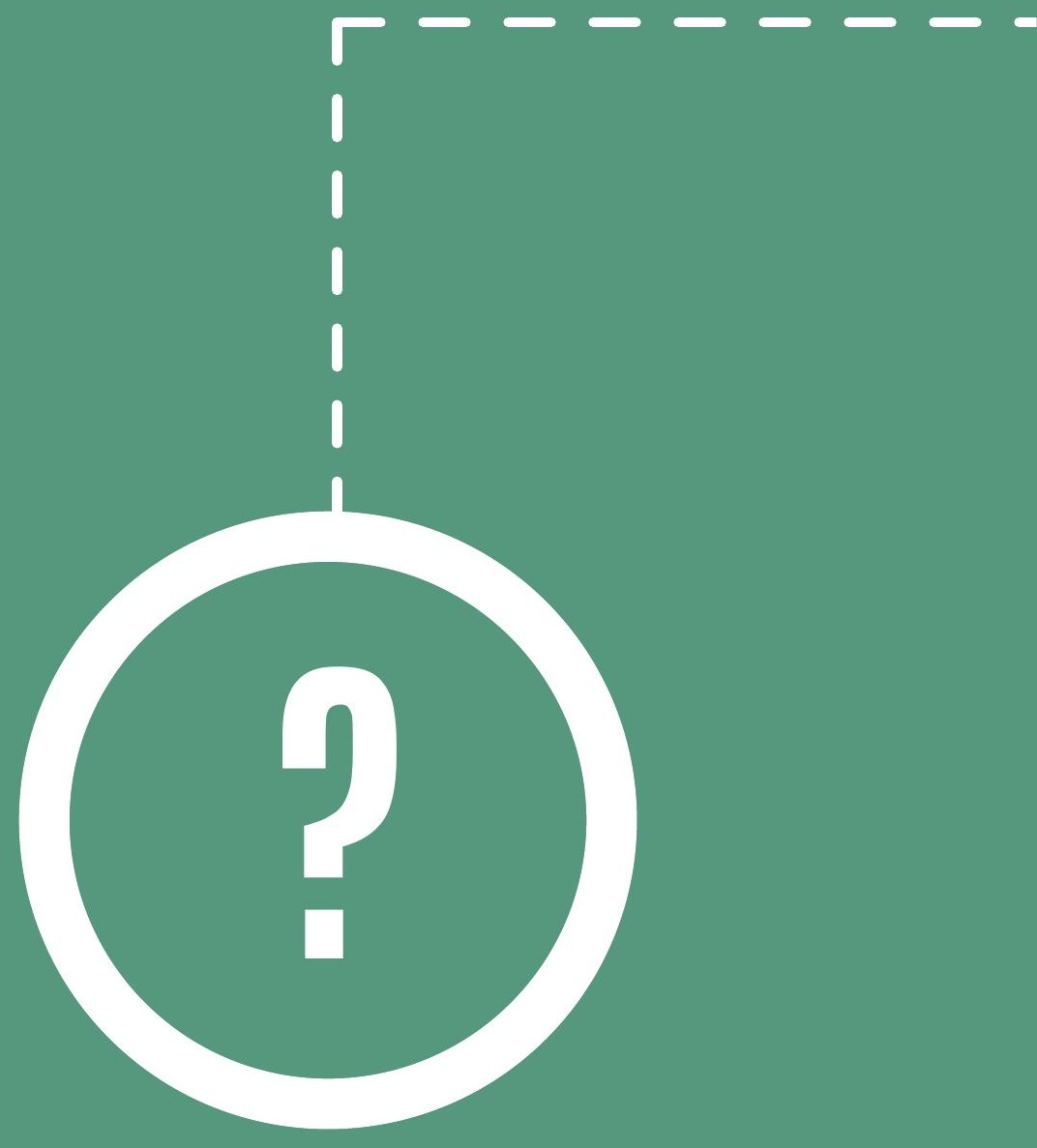




\section{1. ¿ CÓMO LLEGUÉ AQUITY PORQUÉ ME QUEDÉ?}

Yo no sabía lo que realmente es la comunicación. En mi vida siempre tuve una idea estática y lineal de la misma, como profesión la asociaba a los medios y a lo instrumental. Cursando mi carrera de grado tuve un acercamiento a la dimensión gráfica y visual de la comunicación, aprendí sobre códigos, significantes y significados, teorías de percepción, todo siempre de la mano de la técnica y de la práctica misma del acto de diseñar en ejercicios de clase.

Ahora recuerdo un par de profesores en mi carrera que tenían una visión diferente, que pensaban con enfoque social y en términos de ideologías. El profesor Juan de la Cruz Sánchez ${ }^{1}$ tenía a su cargo una asignatura optativa llamada Diseño, Arte e Ideología, la cual no llegó a interesarme lo suficiente como para intentar conocerla a fondo, de manera que lamentablemente no la tomé.

También recuerdo al profesor Antonio Márquez² quien a través de sus clases en la materias de Planeación, Pre-producción y Producción, se esforzaba por hablarnos a los estudiantes sobre la importancia social del Diseño Gráfico, sobre las diferentes posibilidades de materiales y técnicas de fácil acceso midiendo

1. Profesor asistente de tiempo completo de la carrera de DG de la Universidad Nacional de Colombia. Actualmente también es representante de los docentes de la misma universidad.

2. Profesor asistente de medio tiempo de DG en la Universidad Nacional de Colombia. Diseñador gráfico egresado de la misma universidad en el año 1990. 
recursos, e incluso realizaba varias prácticas extra curriculares con grupos de estudiantes interesados en participar en eventos destinados a la difusión de alguna situación de importancia social para la universidad, por ejemplo con jornadas de impresión gratuita de camisetas en serigrafía con mensajes simbólicos. $Y$ aunque como estudiante participé en algunas de ellas, no fue suficiente para marcar una diferencia en mi trayecto, al punto que pasó de largo y yo continué mi camino.

La realidad que yo viví como estudiante, después como profesional y también como ciudadana, es que la función del diseño se ha generalizado durante mucho tiempo y desde muchos puntos de vista desde una sola perspectiva: la consumista. Se ignora desde muchos lugares, que con el diseño se pueden generar estrategias y lograr mejorar aspectos claves para la sociedad.

Me ha sorprendido también descubrir tantos y tan diversos antecedentes históricos desde esta perspectiva en la historia del diseño, encontrarme con pioneros que desde hace décadas están desde lugares diferentes reflexionando en todas estas ideas que apenas hace pocos años han empezado a trascender. Hallar a tantos colectivos y organizaciones que aprovechan los medios virtuales para conectarse con todo el mundo y difundir estos conceptos, ha sido en realidad como descubrir un nuevo mundo.

Estar en este país, conocer personas de diferentes naciones de nuestro continente, lograr amistades valiosas con algunas de ellas, escuchar sus puntos de vista, hablar, leer, intentar entender la comunicación desde otra perspectiva, confundirme, pensar si este realmente era mi lugar, luego por fin entenderlo y saberlo; todo ello me ha dejado en una posición nueva para mí, en la cual siento como un deber actuar para ayudar a que muchos otros la descubran.

Desde esas reflexiones siento que en la práctica, estoy en el adentro, el punto de partida es mi experiencia personal como diseñadora gráfica a lo largo de varios años y algunos más recientes de introversión sobre el carácter de mi profesión y su papel en el mundo, su función, su razón de ser. Siento que he recibido un llamado desde la profesión, desde el diseño mismo, para realizar 
esta tesis. No desde un grupo u organización específico, tampoco desde las escuelas o carreras. Es como si la práctica real de esta tesis fuera nada más que el Diseño Gráfico y, para descubrir el sentido de ese llamado, intervengo en esos espacios para entender mucho más lo que es la profesión y darlo a conocer a quien interese.

Los/las diseñadores/as gráficos/as en su mayoría parecen tener un papel definido dentro de la sociedad, instituido desde la academia. Por experiencia sé que en muchos casos se les señala de cierto modo -como si se tratara de una única y natural manera- cuál será su papel en el mundo y cómo deben incorporarse a él, por ejemplo mediante la práctica de calidad gráfica y técnica y teorías basadas en la semiótica y la percepción, mostrándoles generalmente el camino que los/las conducirá a trabajar bajo las reglas del consumismo. No hay mucho lugar para mostrar caminos alternativos y si se muestran se hace de manera poco atractiva. Uno de mis objetivos es ayudar a mostrar esas otras opciones.

Mi objetivo es descubrir la presencia del Diseño con Consciencia Social en los planes curriculares de las carreras de Diseño Gráfico en dos universidades públicas de América Latina. Considero muy importante aclarar que no se trata de un análisis de todo el pénsum o plan curricular y que mi interés no es cuestionar el qué y cómo del planteamiento total de cada carrera universitaria, sino descubrir la presencia del Diseño Gráfico con Consciencia Social en ellas y a partir de allí analizar de qué manera se presenta a los estudiantes esta perspectiva.

Tomo como casos los planes de estudio vigentes en 2015 de las carreras de Diseño Gráfico de la Universidad Nacional de Colombia y de la Universidad de Buenos Aires.

Elijo la Universidad Nacional de Colombia, ya que de allí egresé como diseñadora gráfica, por tanto cuento con cercanía y conocimiento de su actividad, y contacto con otros egresados y docentes que me sirvieron de aporte importante en este proceso. Esta universidad también ha sido considerada desde hace varios años la de mayor nivel académico en Colombia. 
La Universidad de Buenos Aires la tomé como lugar de práctica porque es la más destacada en Argentina y uno de las más reconocidas a nivel latinoamericano por su calidad académica, además la carrera de Diseño Gráfico cuenta con diversas cátedras con enfoque diferentes que serán interesantes de analizar desde el punto de vista de esta tesis.

Me decidí a nombrar el tema específico de esta tesis como Diseño Gráfico con Consciencia Social porque desde mi punto de vista esta expresión abarca todos los aspectos que le corresponden, sin embargo encontré que existen diferentes términos que se difunden de forma circunstancial refiriéndose a este tema y que justamente le dan una mayor relevancia a uno u otro aspecto:

Diseño social: generalmente se refiere al diseño enfocado en el beneficio de las personas por encima del mercado. El/ la diseñador/a es conciente y responsable del mensaje que va a comunicar con imágenes. Habitualmente los/las diseñadores que hacen diseño social lo hacen para organizaciones sin ánimo de lucro.

Diseño sustentable: algunas veces se refiere al diseño que contribuye a cuidar el medio ambiente. Los/las diseñadores tienen en cuenta el tipo de materiales, las cantidades y el tipo de proceso que se va a utilizar para elaborar los productos diseñados.

Diseño democrático: es el encaminado en lograr que la mayoría de personas accedan al diseño, como usuarios finales, como clientes y como ciudadanos, independientemente de su posición social o económica en el sistema.

Diseño participativo: es aquel que permite que el llamado cliente contribuya en el proceso de diseño más allá de ser un simple emisor de información y datos para ser parte fundamental del resultado aplicado.

Mi intención es condensar todas estas orientaciones, mostrando las diferentes perspectivas que se me han presentado en la investigación y descubriendo cómo todas y otras más, 
conforman para mi el diseño con consciencia social del que hablo en esta tesis, todo ello en relación directa con el trabajo y la producción desde la empresa, la ciudadanía, las políticas públicas y por supuesto desde la universidad latinoamericana.

Desde la mirada de la educación, quiero hacer referencia a una reflexión de Daniel Prieto Castillo: "Lo comunicacional en el hecho educativo es mucho más profundo, se relaciona con la comunicación con mi propio ser, con mi pasado, con las interacciones presentes y con el futuro. ( )La relación pedagógica es en su fundamento una relación entre seres que se comunican, que interactúan, que se construyen en la interlocución" (Castillo, La comunicación en la educación, 2011).

Desde ahí quiero entender cómo se ayuda a descubrir al estudiante de diseño sus capacidades y hacia qué lugar enfocarlas. Qué contextos se hacen visibles a estos estudiantes y en ellos en qué medida aparece el concepto Diseño con Consciencia Social.

La educación está de raíz relacionada con la comunicación por el simple hecho de que los humanos somos seres que nos relacionamos y "no podemos soñar con transformaciones educativas sin jugar hasta las entrañas nuestra necesidad y capacidad de comunicarnos". (Castillo, Diseño y comunicación, 1980). El Diseño Gráfico con Consciencia Social es la dimensión que quiero analizar en ese escenario, enfocado en una comunicación entre personas, tal como ilustra Jorge Frascara: "En suma, los diseñadores son especialistas en Comunicación humana, y su medio específico es el visual" (Frascara, El diseño de comunicación, 2011), donde no se centre solamente en crear los objetos de diseño, donde la creación de estos medios de transmisión (libros, revistas, afiches, etc.) no sean el final del proceso de diseño, sino su inicio. "El problema fundamental no es el acto comunicacional en sí, sino el impacto que esa comunicación tenga en el conocimiento, actitudes o conductas de la gente". (Frascara, El diseño de comunicación, 2011)

Al realizar esta tesis, me interesa hacer un estudio comparativo de los planes curriculares de ambos casos estudiados para reconocer 
la presencia del Diseño Gráfico con Consciencia Social en ellos. Pretendo conocer la mirada de los/las estudiantes y egresados/ as para saber en qué medida son conscientes del significado de comunicar a través de la imagen y también la mirada de los/las docentes de las academias, en tanto profesionales activos/as o no, del Diseño Gráfico en la sociedad.

Relevo y describo una muestra de organizaciones y movimientos sociales del mundo del diseño que trabajan desde la perspectiva del Diseño con Consciencia Social, así como los eventos de tipo político y académico que se organizan a nivel regional cuyo objetivo principal es el diseño y la comunicación con consciencia social.

A su vez, presento una descripción de las políticas públicas de estos países, en las cuales implementen el diseño como eje de transformación social (Políticas Públicas de Diseño).

Finalmente, presento un acercamiento a la estructura de una propuesta de seminario universitario que aborde este tema directamente y lo presente a los alumnos como una opción viable y necesaria.

Esta tesis contribuirá a fortalecer la responsabilidad, solidaridad, profesionalismo, creatividad y consciencia de comunidad enfocada a la sociedad, a sus necesidades, a sus deseos y a sus cambios, desde la profesión del Diseño Gráfico y la comunicación. Ayudará a que estudiantes, docentes y profesionales re evalúen su rol y lo que significa su trabajo, que lejos de tratarse del desarrollo de una pieza aislada con la única función de transmitir un mensaje, se trata de comunicar o de producir sentidos.

Pondrá sobre la mesa el papel de la universidad pública, la cual ha tenido una posición fundamental en la sociedad como formadora de profesionales de diferentes disciplinas comprometidos con el desarrollo de la misma. Si no se atiende esta necesidad de reestructurar la enseñanza de los/las profesionales del diseño, se continuará mostrando la tendencia de entender el Diseño Gráfico sólo como herramienta u oficio, 
no como saber, ignorando sus capacidades para intervenir en la sociedad y en los diferentes territorios, entendiendo que su papel no está solamente en colaborar con organizaciones sociales o sin ánimo de lucro, sino en una consciencia completa sobre las consecuencias y efectos de cada uno de los proyectos en los que participa, desde el concepto que comunica, pasando por el trabajo de campo para captar las sensibilidad del territorio, hasta el material que propone utilizar para imprimir o difundir dicho concepto.

A nivel de el/la diseñador/a, sea un/a profesional activo/a, un/a docente o estudiante, esta tesis será un aporte para que se reconozca con mayor precisión la función de su profesión y por tanto, tendrán a la vista opciones reconocibles, más allá del camino mostrado desde la academia, es decir, servirá también para crear consciencia de poder elegir.

Esta tesis colaborará con la difusión de las muchas posibilidades que hay, si se tiene la voluntad de hacerlo, para implementar poco a poco algunas prácticas dentro de la profesión que vayan encaminadas a la responsabilidad y consciencia del trabajo que se realiza.

\subsection{Mi problema, mi oportunidad}

Mi interés en el tema del Diseño con Consciencia Social se convirtió en mi problema y en mi oportunidad, cuando me di cuenta de lo grande y trascendente que es el concepto, no solo en lo académico, sino para la profesión entera y para la vida de quienes trabajamos en ello.

Aprendí en PLANGESCO que un problema comunicacional es una situación en donde es necesaria la intervención de la comunicación como proceso para facilitar entendimientos. En esta tesis, hay una línea de comunicación establecida.

Para muchas personas, los/las diseñadores/as son los/las profesionales que trabajan en función del capitalismo y como 
instrumento de la publicidad comercial. En ese contexto, por experiencia puedo decir que ese concepto muchas veces se entiende como positivo, ya que los/las diseñadores/as más "exitosos" son quienes trabajan para multinacionales, son quienes más cobran por su trabajo y más ganancias económicas obtienen.

Por otro lado, quienes deciden trabajar conscientemente con objetivos más sociales, algunas veces son estigmatizados por no tener intereses exclusivamente económicos y querer utilizar la profesión para causas no consumistas. E igualmente, desde este lugar, se estigmatiza a los primeros, por trabajar bajo las reglas del capitalismo, sin embargo son muchos/as los que ni siquiera tienen consciencia de las alternativas que tienen para ejercer la profesión. Es entonces allí donde yo como facilitadora/comunicadora y desde esta tesis, debo empezar rompiendo estigmas.

Si miro desde el lugar de la relación entre diseñador/a, cliente y usuario/a, veo que muchas veces el/la profesional del diseño no se pone en lugar del otro, sino que trabaja creyendo que es poseedor/a de la verdad y que nadie como él/ella sabe cómo solucionar determinado problema gráfico, a veces a quien menos se considera es al usuario final, pasando primero por los gustos del/la diseñador/a, de las solicitudes del cliente o simplemente por las tendencias del mercado. Aunque todos estos aspectos hay que tenerlos siempre en cuenta en un proceso de comunicación gráfica, no se puede ni debe olvidar la existencia de ese otro, que en este contexto, además sería el ente receptor entendiéndolo como aquél que reacciona y en quien recaen las consecuencias de los diseños creados, con efectos ideológicos, físicos, ambientales, etc.

En ese rol de facilitador/a el/la diseñador/a debe entender que el "otro" es como el "yo", capaz de actuar y de pensar; que su capacidad de pensamiento es igual a la suya en su totalidad; que análogamente a su vida, la de él muestra la misma forma estructural-temporal con todas las experiencias que ello conlleva. Significa, conjuntamente, ponerse en el lugar del otro, en un diálogo permanente, surgiendo la interacción social. Y a la vez, ayudar a entender a ese otro de la misma forma con sus pares. 
En el tiempo que llevo moviéndome en el mundo del diseño, he visto el concepto generalizado de Diseño Gráfico capitalista, impartido en muchas ocasiones desde las universidades, ya que en nombre de la función comunicacional del diseño, algunos/as docentes siembran en sus estudiantes la idea de diseñar según lo que el/la cliente solicite, prestando una asesoría moderada, donde quien paga por un servicio y /o producto tiene la razón, todo en favor de un supuesto cumplimiento de la profesión. Se crea así un concepto que parece natural, que amalgama a los/ las diseñadores/as en un grupo de profesionales cuyo objetivo es ayudar a vender a otros, en donde no se piensa en la reacción producida ni en las consecuencias del trabajo realizado ${ }^{3}$. (Gramsci.org.ar)

Ahora descubro que el diseño consciente, responsable, democrático y participativo resiste al diseño consumista. Implica cambiar el orden de lo instituido, entendiéndose aquí como poder a la fuerza capitalista bajo el cual trabaja el diseño puramente comercial. A éste resisten los movimientos y colectivos que trabajan con los mismos instrumentos pero de manera consciente y responsable, tanto en forma como en contenido, tal como Foucault lo decía a través de sus conceptos resistencia - poder ${ }^{4}$. (Díaz Giraldo, 2006)

En otras palabras, esta tesis aborda un problema enmarcado en un contexto en el cual hay que poner especial atención a

3. Identifico aquí la noción de hegemonía de Antonio Gramsci, según la cual el poder de las clases dominantes sobre las sometidas en el modo de producción capitalista, está dado primordialmente por la hegemonía cultural que se ejerce, a través del control del sistema educativo, de las instituciones religiosas y de los medios de comunicación. Así, las clases dominantes educan a los dominados para que estos vivan su sometimiento y la supremacía de las primeras como algo natural y conveniente, inhibiendo así su potencialidad revolucionaria.

4. Focault concibe la resistencia como parte del poder, no como algo que se opone a éste. Para el autor el poder no es una realidad inmutable y con existencia sólida. El poder es una dinámica constante, una relación de fuerzas que sin detenerse se enfrenta en lo cotidiano entre intereses y necesidades. No es algo que tenga una expresión horizontal, vertical, o viceversa, sino que atraviesa toda la sociedad, a la vez constituyéndola y transformándola. Foucault no parte de la concepción tradicional del poder, como poder solamente coercitivo y represor, sino que el poder también produce, las prácticas de poder funcionan productivamente, gestan, entre otras cosas, al individuo, al sujeto. 
REDISEÑANDO MUNDOS

los procesos comunicacionales: la academia universitaria pública; a su vez, este problema trata un tema que es en sí mismo comunicación: el Diseño Gráfico, y no el universo del gráfico en general, sino particularmente el diseño creado con responsabilidad, consciencia y sentido social; y por último, cómo en ese contexto la consciencia de comunicación desde esta perspectiva contribuye a la formación de nuevos comunicadores visuales. Toda esta tesis gira en torno a la comunicación para la transformación. 



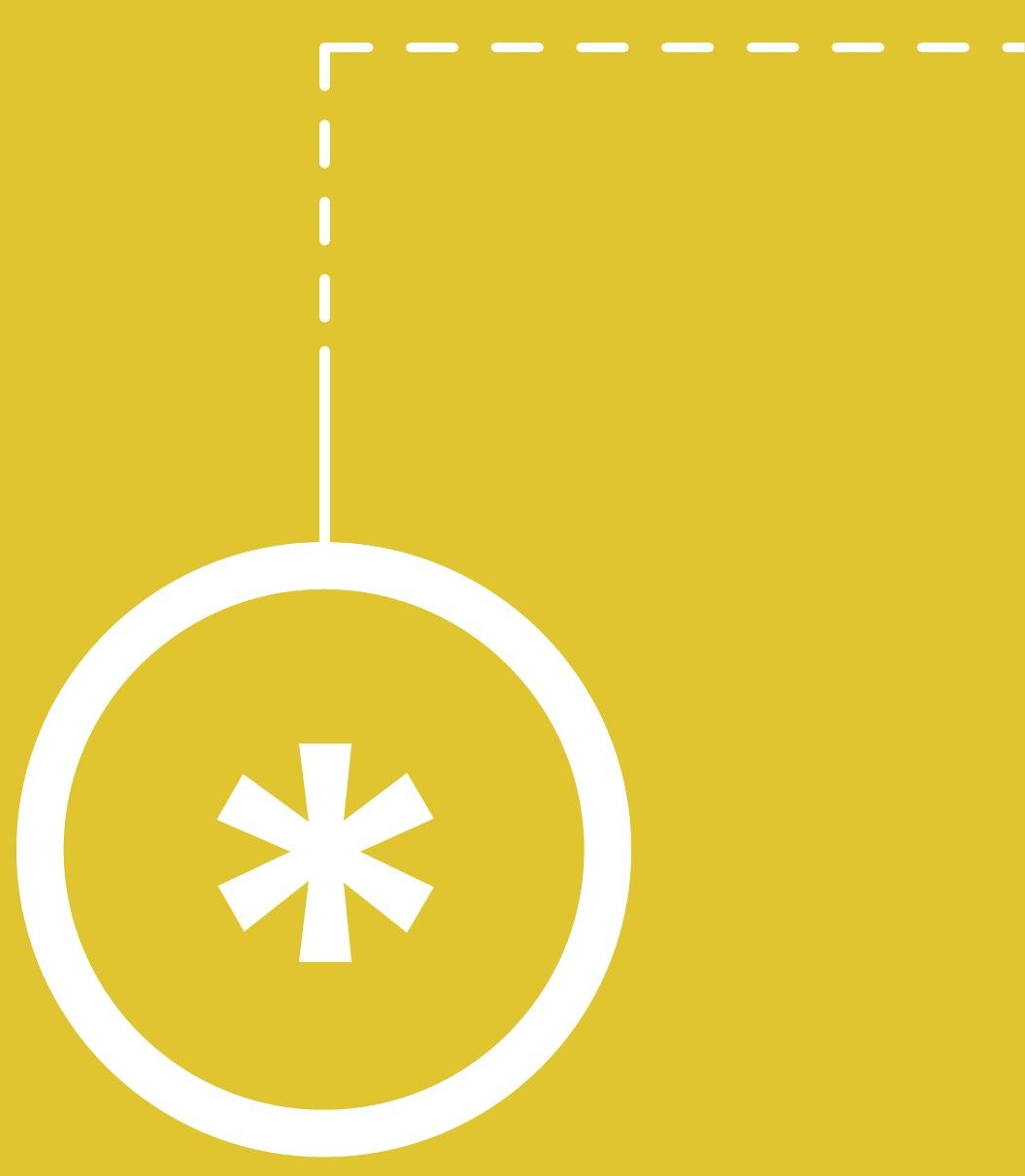




\section{RED DE CONCEPTOS}

\subsection{La imagen, ¿para qué?}

Antes de iniciar el camino de búsqueda de las presencias de la perspectiva de la consciencia social en el campo académico del Diseño Gráfico, me parece oportuno y necesario dar una mirada a lo que actualmente se entiende por esta disciplina, en el medio académico y profesional.

Diseño Gráfico, Diseño Visual o Diseño de Comunicación Visual, dependiendo del contexto y del lugar, esta profesión se nombra de diferentes maneras, que en últimas tiene como materia prima siempre la imagen. Pero la imagen, ipara qué? Tal vez se podría decidir cuál de estos términos usar al descubrir la respuesta a esa pregunta, o tal vez lo ideal sería que independientemente de las palabras, el objetivo final fuera el mismo y que cada una lo tuviera implícito.

No son pocos quienes consideran un poco más amplio y preciso hablar de Diseño de Comunicación Visual, "esta definición incluye los tres elementos requeridos para distinguir un campo de actividad; un método: diseño; un objetivo: comunicación; y un medio: la visión". (Frascara, El diseño de comunicación, 2011).

La realidad es que en muchas de las diferentes instituciones de educación superior, dentro de lo que conozco, universidades o 
escuelas, prima todavía el término Diseño Gráfico, siendo este el más tradicional y el que apunta a referirse directamente a lo que significa la producción de gráfica pura, independientemente de su soporte: pantalla, papel, plástico, etc. Para el objetivo de esta tesis lo continuaré nombrando aquí como Diseño Gráfico (DG), ya que para mi y como lo dije antes, esas palabras idealmente ya implican un significado poderoso.

Aunque no existe una claridad o verdad mundialmente aceptada sobre los orígenes del DG, ya que para algunos historiadores se da desde los primeros hallazgos de las cuevas de Altamira, para otros en el Renacimiento o para otros tantos más recientemente en Alemania en la escuela Bauhaus ${ }^{5}$, me parece necesario dar un vistazo a algunos antecedentes que considero importantes a modo de contextualizar el tema.

No es mi intención extenderme en una historia del DG en general, sin embargo creo significativo situarlo en un momento y espacio determinado para tener cierta claridad antes de avanzar, además de lo que hoy podemos entender como DG, el cómo ser y hacer del diseñador gráfico como ser humano, profesional de esta época y en este continente.

\subsection{Una historia de los objetos de diseño gráfico}

Entendiendo que las disciplinas son históricas, el diseño no es la excepción. Ha estado en relación con procesos y situaciones determinantes que le han permitido avanzar de una u otra forma de acuerdo al contexto, al momento y a diversas condiciones sociales, culturales, económicas y políticas que se dan en forma continua y que generan consecuencias. En esta parte tomaré en cuenta la historia oficial del DG difundida en diversos textos que

5. Escuela fundada en 1919, en Weimar (Alemania), por Walter Gropius, trasladada en 1925 a Dessau y disuelta en 1933 en Berlin. Uno de los principales ideales de Gropius era representado mediante la siguiente frase: "La forma sigue a la función", ya que buscaba la unión entre el uso y la estética. Además creía en las enseñanzas artísticas como base para una transformación de la sociedad burguesa de la época, de acuerdo con su pensamiento socialista. 
se estudian actualmente en las academias y facultades en América Latina, es digamos, la historia aceptada del DG. Una historia que lo ha abordado a través de:

"la historia de las producciones de cosas, con todos los riesgos que esto conlleva.(...) Por un lado las ideas, por el otro los objetos. Y a la hora de clasificar, el universo de lo datable, fechable y separable está al lado de la cosa. La historia del DG ha tomado a la humanidad como un conjunto homogéneo de concepciones de mundo y ha clasificado sus objetos, sus producciones, con un parámetro que parece ser universal, pero que podemoslegítimamente- considerar contemporáneo". (Devalle, 2009).

Con la claridad de lo enunciado anteriormente y gracias a los textos de Verónica Devalle ${ }^{6}$, inicio esta referenciación histórica con el descubrimiento personal de que esa manera de historizar el diseño, es una de las principales causas de que aún hoy en día siga primando el objeto sobre el concepto y de que justamente el objetivo final de la práctica del DG sea el resultado y no el proceso.

\subsection{Puntos de referencia en la historia conocida}

Muchos aspectos políticos, sociales y religiosos de cada época, han influenciado el desarrollo del DG, desde la aparición de los libros, periódicos y carteles, la creación de los tipos de letras y, más recientemente, el avance de las nuevas tecnologías que ha permitido que el DG expanda sus horizontes hacia el diseño web, el diseño multimedia y las artes audiovisuales. Es como si el diseño existiera en absolutamente todo nuestro entorno, pasado y presente, a donde miremos habrá diseño.

6. Verónica Devalle es licenciada en Sociología, doctora en Artes por la Universidad de Buenos Aires y Magíster en Sociología de la Cultura y Análisis Cultural por la Universidad de San Martín. Es profesora de la Universidad de Buenos Aires en la carrera de Diseño Gráfico. Es coordinadora y profesora de la Maestría en Diseño Comunicacional en la misma universidad. Es investigadora del Conicet y directora de proyectos UBACyT, en la Facultad de Artes de la Universidad de Buenos Aires. Sus temas articulan reflexiones sobre el arte, el diseño y la cultura visual contemporánea. 
Es en algún momento entre el Renacimiento y el Barroco que van apareciendo concepciones del diseño en significación amplia (no aún identificado específicamente como gráfico): como proyecto, como dibujo, como obra de arte o arte aplicada.

“Proyecto, dibujo y obra es la tríada que acompañó la concepción del diseño hasta las postimetrías del siglo XIX, momento en el que, de manera paralea a la complejización de los procesos de producción y distribución de los productos, se complejiza el ámbito del diseño (...). Los inicios de la especialización entre las distintas ramas del diseño (industrial, gráfico, textil) coinciden con el desarrollo de la cultura industrial (...). El desarrollo de la especialización de las nociones de "los diseños" y su "separación" de la arquitectura se da a medida que se va ensanchando la distancia entre "obra" y "objeto". La división del trabajo propia de la segunda revolución industrial, trajo aparejada la división entre quienes proyectaban y quienes ejecutaban el producto". (Ledesma, 2010).

En el siglo XIX, en Gran Bretaña se destacó William Morris quien en medio de esta revolución, fundó el movimiento Arts and Crafts, para contrarrestar de algún modo el creciente avance de la producción en serie que trajo la industrialización. Quería rescatar las artes y oficios medievales para lograr cierta reivindicación de la supremacía del hombre sobre la máquina y tenía la idea de terminar con la división del trabajo. Sin embargo es sabido que los productos que desarrolló en su empresa finalmente no pudieron competir con los precios de los productos en serie y terminaron siendo adquiridos por grupos de élite, paradójicamente con lo que en principio quiso promover.

No obstante:

"La acción de Morris fue decisiva en la evolución de la noción de diseño en dos sentidos: en primer lugar, por la claridad con que tomó partido al vincular la actividad proyectual del mundo de los objetos con el mundo del arte, la exaltación del mundo artesanal y de la producción de una obra individual con contenido propio y como corolario, por la inauguración de una tendencia de largo aliento en el diseño: la del producto único, exclusivo. Si bien el corolario no se desprende del ideario 
fuertemente socialista, fue la consecuencia necesaria de un hacer puramente artesanal y artístico de la era de la máquina. El diseño gráfico y el diseño industrial son en gran parte, herederos de ese gesto" (Ledesma, 2010).

Así, empieza surgir la idea de DG, independiente del concepto general de diseño y bajo una ideología social interesada en construir una nueva realidad. Sin embargo el modernismo no tardó en ser tomado por la burguesía industrial y comercial, encontrando allí la respuesta a esa necesidad de cubrir sus ambiciones con objetos nuevos, especiales y únicos (Ledesma citando a Enric Satué, 2010). Objetos que debían competir en medio de ese creciente mercado, debían diferenciarse y marcar un contraste si querían tener éxito, y es ahí cuando aparece el diseño de identidad y publicidad gráfica, un factor decisivo en el proceso de producción y venta.

\subsection{Latinoamérica en ese contexto histórico de objetos}

Nuestro continente tuvo un desarrollo temprano en el oficio gráfico, desde el uso de la imprenta hasta la publicidad, siguiendo la línea de historizar los objetos y aplicaciones gráficas, puedo referenciar algunos de los hechos más destacados.

En México se establece la tipografía en 1539, fray Juan de Zumarraga es el autor del primer libro impreso en América, casi doscientos años antes de la famosa Biblia de Gutemberg. Durante el siglo XVIII se ocuparon básicamente de reproducir imaginería religiosa, poco después en 1830, la litografía se ocupó también de esos menesteres añadiendo sátiras de costumbres y caricaturas políticas en periódicos similares a los europeos.

El primer periódico editado en Venezuela en 1808, marca los orígenes de la imprenta en este país, y la iniciativa de mejorar el diseño de los sellos de la Administración de Correos se debió a un grupo de diseñadores y artistas venezolanos en la que optimizó notablemente la calidad del diseño de ese país. Igualmente Gerd Leufert (1914, Alemania -1998, Venezuela) fue autor de 26 sellos para la Administración de Correos y es calificado como el padre del 
DG venezolano. Y M.F. Nedo (Italia, 1926 - Venezuela, 2001), es el segundo pionero moderno del diseño venezolano quien inició su larga e intensa colaboración con Gerd Leufert en la agencia de publicidad McCann Erickson.

En Perú, Claude Dieterich (1930), es considerado el pionero del DG moderno, quien se destacó por implementar las influencias europeas en el DG contemporáneo de América Latina, debido a que trabajó en Paris en diversas agencias de publicidad y en el diseño de revistas.

Arnaldi y Valerian Guillard, son representantes de la influencia francesa en Argentina a través del diseño de sus carteles. También se destaca como la potencia en edición e impresión de libros y diarios en los años sesenta. Aunque sin duda es en ilustración donde ha tenido su papel más reconocido con Castagnino, Sabat, Quino, Mordillo y Tomás Maldonado.

La tipografía llega tarde a Brasil, pero a pesar de esto el establecimiento de las sucursales de las grandes agencias de publicidad norteamericanas, que coincide con el primer gran desarrollo industrial y mercantil del Brasil, permite la introducción de las más modernas formas de producción industrial, por lo que los brasileros aprenden a diseñar anuncios publicitarios en 1940.

En Cuba se desarrolló probablemente mucho antes que en cualquier país de Latinoamérica un movimiento notable de diseño aplicado al consumo de la industria del tabaco. Los personajes destacados en el diseño cubano en litografía son Francisco Murtra, José Mora y su tipografía y el cartelismo de Félix Beltrán.

Esta veloz mirada a referencias históricas del DG y sus formas de representación, nos muestra que en la gran mayoría de sus aplicaciones se han agrupado en lugares que se vinculan directamente con fines principalmente consumistas, o por lo menos son estas piezas las que más han quedado en el imaginario del público receptor y por ello se ha construido una historia con base en la aparición y desarrollo de esos objetos de diseño. 
La presencia de la imagen ha sido en muchas ocasiones sigilosa, convirtiéndose muchas veces en uno de los instrumentos del consumismo para instalar sutilmente necesidades creadas y paradigmas de vida. El teórico argentino Daniel Prieto Castillo, ya en 1980 dice:

"De ninguna manera los mensajes determinan la vida cotidiana (por ejemplo, la publicidad no produce el consumo). En todo caso son reforzadores de pautas, de formas de existencia ya vigentes. Los mensajes no alienan a nadie. La presencia de formas y contenidos alienantes es señal de consumidores previamente alienados. Son, siempre, las relaciones sociales vigentes las que resultan alienantes. Pruebas de esto no faltan. Los grupos sociales más indefensos tienden a consumir mayor cantidad de mensajes (por ejemplo: los niños, los ancianos, los marginales, los obreros que gastan la mayor parte de su tiempo en el trabajo). Como forma de ocio el consumo de mensaje suple a otras maneras de utilizar el tiempo libre (creatividad, deportes) [ ] Lo importante de la vida cotidiana alienada (lo importante para quienes con eso se benefician) es que se esté en ella sin tomar consciencia de esa condición". (Castillo, Diseño y comunicación, 1980).

Hoy en día con mucha fuerza, es el diseño de identidad y todo lo que de él deriva (merchandising, envases, flyers, pautas, carteles, etc.) uno de los ejemplos más notables de esa función comercial del DG dentro del capitalismo. En el diseño de identidad se configuran una serie de signos para llegar antes que el otro a los ojos del potencial consumidor, salir a flote en medio de la maraña de imágenes que todos los días bombardean la mirada de las personas, destacarse en medio de la competencia, todo con un objetivo conocido: consumir. De esta manera la característica propia del mercado capitalista es transferida al mundo de la imagen: velocidad en la competencia frente a los consumidores.

Afortunadamente para muchos y a pesar de ese olvido teórico (Devalle, 2009) en su historización, el DG cuenta con diversas dimensiones, una de las cuales apunta al papel social que también ha desempeñado a lo largo de esa historia. Quiero resaltar ciertos momentos que son representativos a nivel mundial y otros más específicamente en Latinoamérica, donde el diseño ha estado presente como instrumento esencial en los procesos 
de comunicación y donde "varios diseñadores han visto en su profesión un instrumento de cambio de pensamientos" (Pelta, Diseño y Activismo, 2012).

\subsection{Diseño gráfico para la transformación ${ }^{7}$}

Desde William Morris como lo mencioné antes, en el siglo XIX, había una ideología de transformación bajo una perpsectiva social, con una consciencia de necesidad de crear ambientes sanos y de mejorar la situación social de los trabajadores, que desembocó, por ejemplo, en la orientación seguida por los arquitectos y diseñadores racionalistas de las décadas de 1920 y 1930, quienes pretendían aplicar los conceptos que surgieron en la época al momento de diseñar: practicidad, utilidad, simplicidad, comodidad, funcionalidad y sobriedad. Es decir, no preferir lo decorativo a lo funcional.

El Futurismo, el Dadaísmo y el Constructivismo ruso manifestaron un alto grado de compromiso político y/o social que inevitablemente desembocaron en el diseño. El Futurismo demostró una gran voluntad comunicativa utilizando fotomontajes y tipografías agresivas. El Dadaísmo se caracterizó por rebelarse en contra de las convenciones literarias y artísticas y, especialmente, por burlarse del artista burgués y de su arte (Ver imágenes en inserto).

El movimiento De Stijl, formado en Holanda en 1917, también quiso transformar el mundo, ya que no sólo se trataba de un movimiento artístico sino del ideal de organizar de manera completamente nueva la vida social y cultural para conseguir la creación de la armonía universal, presente en todo cuanto rodea al ser humano. Los miembros de este grupo estaban profundamente comprometidos con el clima espiritual e intelectual de su tiempo y tenían el objeivo de expresar la consciencia de su generación. De Stijl buscaba las leyes universales que gobiernan la realidad visible, pero que se encuentran escondidas por las apariencias externas de las cosas (Ver imagen en inserto).

7. Ver infografía \#1. 


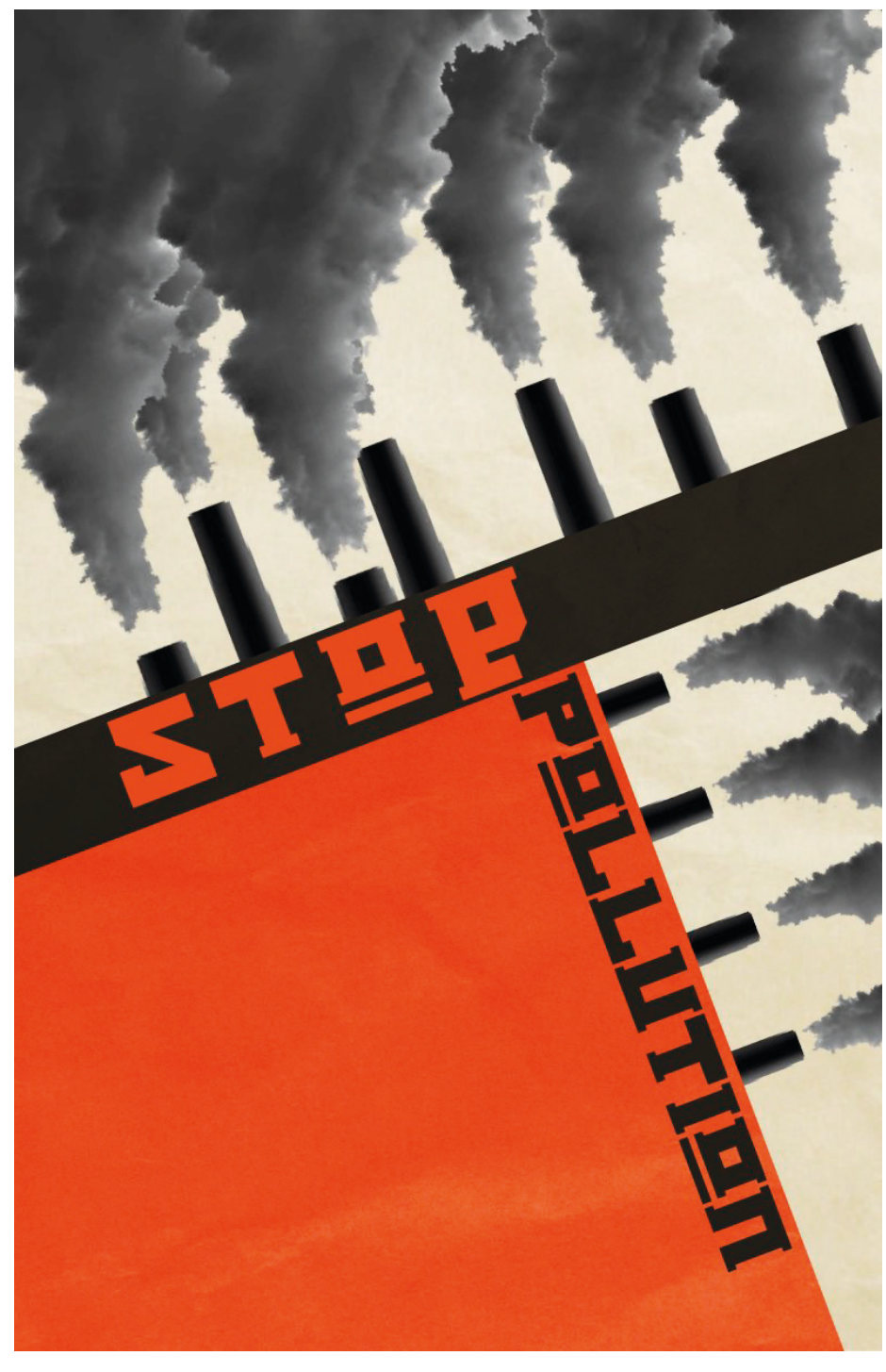

Constructivismo. Autor: Gustav-Klutsis Tomado de http://90mas10.com/

\section{DE STIJL \\ MAANDBLAD VOOR NIEUWE KUNST, WETENSCHAP EN KULTUUR. REDACTIE: THEO VAN DOESBURG. PER JAARGANG. ADRES VAN REDACTIE EN ADMINISTR. HAARLEM MERSTRAAT 73A LEIDEN (HOLLAND).

4e JAARGANG No. 11.

\section{LETTERKLANKBEELDEN (1921)}

IV (in dissonanten)

$\begin{array}{llll}U^{\prime} & J- & m^{\prime} & n^{\prime} \\ U & J- & m^{\prime} & n^{\prime} \\ V_{-} & F- & K^{\prime} & Q^{\prime} \\ F^{\prime} & V_{-} & Q^{\prime} & K^{\prime} \\ X^{\prime} & Q^{\prime} & V^{\prime} & W^{\prime} \\ X^{\prime} & Q^{\prime} & W & V \\ U^{\prime} & J_{-} & m- & \end{array}$

A- O-

$P^{\prime} B^{\prime}$

$\mathrm{A}-\mathrm{O}-$

PI $\mathrm{B}^{\prime}$

D - T-

O' E-

d $t$

$\mathrm{O}^{\prime} \mathrm{EI}^{\prime}$

$B^{\prime} D^{\prime}$

$$
Z^{\prime} C S
$$

Aanteekening: te lezen van links naar rechts. Voor de teekens zie men Stijl no. 7 Proyecto gráfico (con el pseudónimo I.K. Bonset), 1921 


\section{DISEÑO GRÁFICO PARA LA TRANSFORMACIÓN}

\section{EJEMPLOS DESTACADOS}
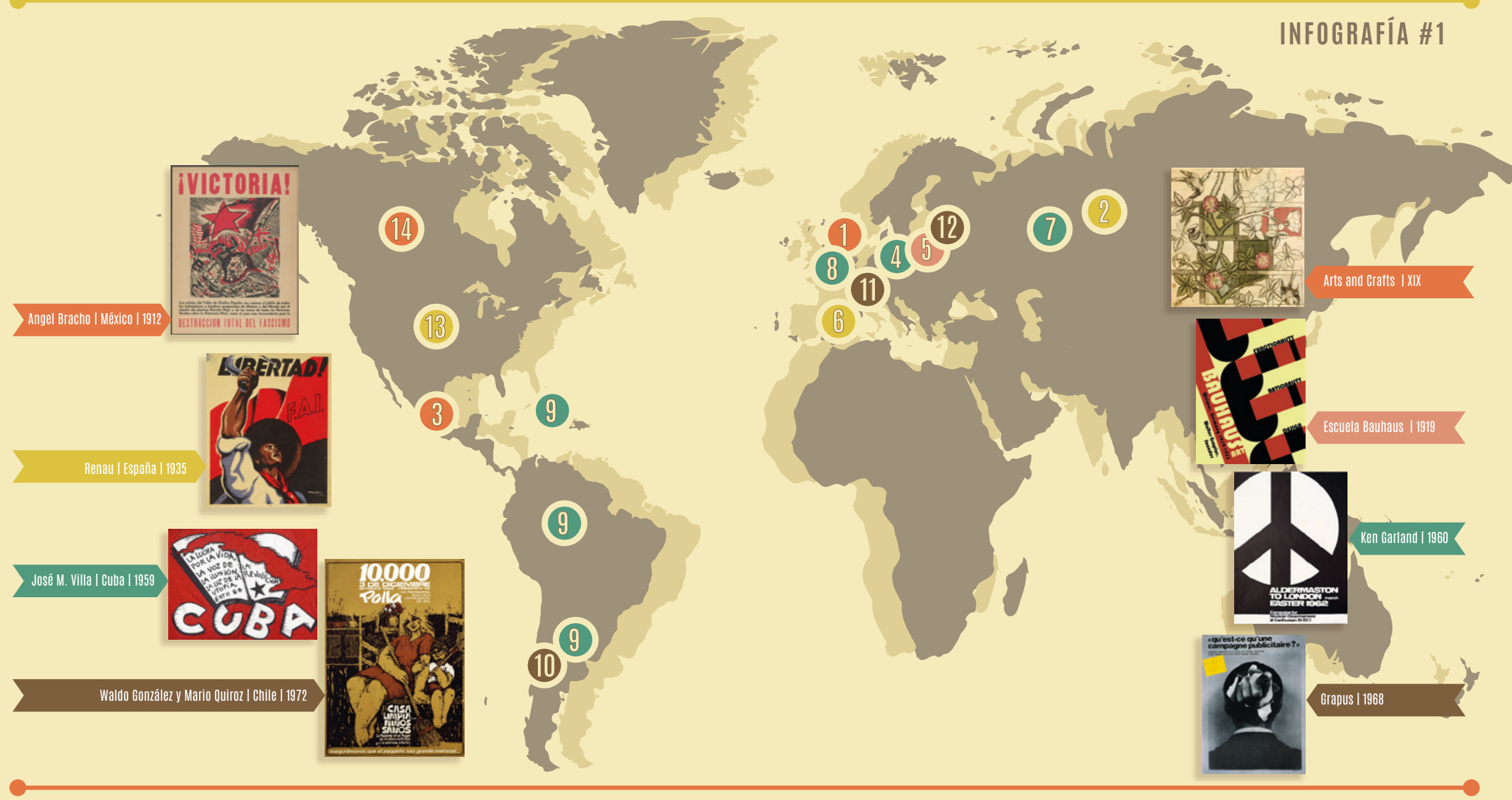

1. Siglo XIX | Gran Bretaña | William Morris

6. 1936 | Guerra Civil Española y

movilización de cartelistas.

funda el movimiento Arts and Crafts.

2. Primeras décadas del siglo XX | Rusia

surgen los movimientos Futurismo,

Dadaísmo y Constructivismo.

3. 1910 | Revolución mexicana | Sandino

en Nicaragua.

4. 1917 | Holanda | De Stijl

5. 1919 | Alemania | Escuela Bauhaus, su

principio fundamental era: "La forma sigue

a la función".
7. 1945 | Propaganda y cartel soviético de

protesta | Aleksandr Ródchenko.

8. 1960 | Ken Garland | Campaña de

Desarme Nuclear | Manifiesto First Things First.

9. 1959 | Cuba | La revolución y el

gobierno socialista. comandado por Fide

Castro | El marxismo, la matriz de

pensamiento más difundida entre los 60 y los 80 en América Latina desde las universidades públicas.

10. 1960 | Primeros signos de identidad del cartel político de la izquierda chilena.

11. 1968 Gérard Paris Clavel, Pierre Bernard y François Miehe fundan Grapus,

12. 1971 | Aparece el libro de Victor Papanek Design for the Real World.
13. Década del 80 | fundación en Nueva York del grupo de activistas ACT UP. 14. $2000 \mid$ Actualización del manifiesto First things First (1964). 


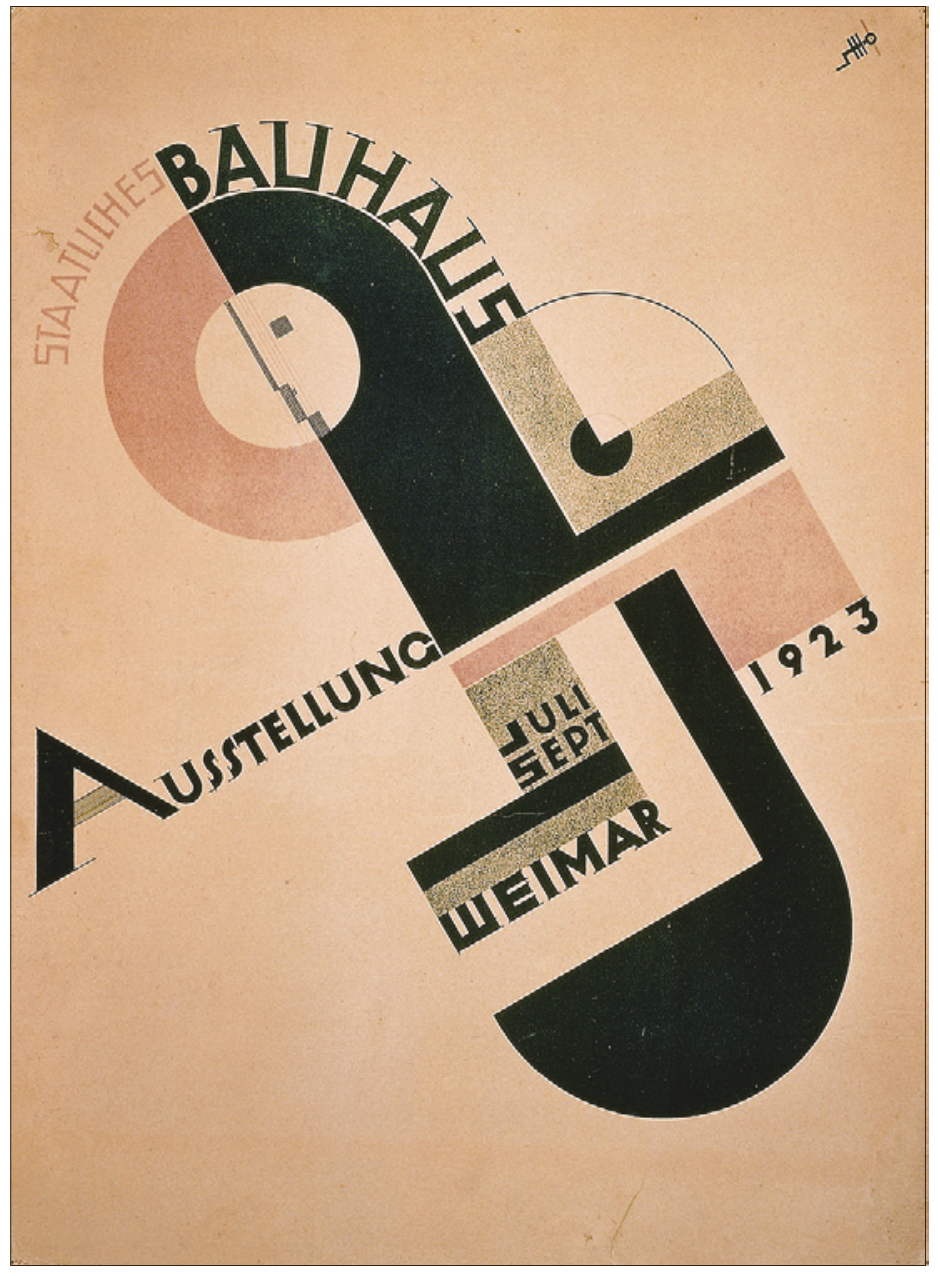

Bauhaus. Autor: Joost-Schmidt, 1923 


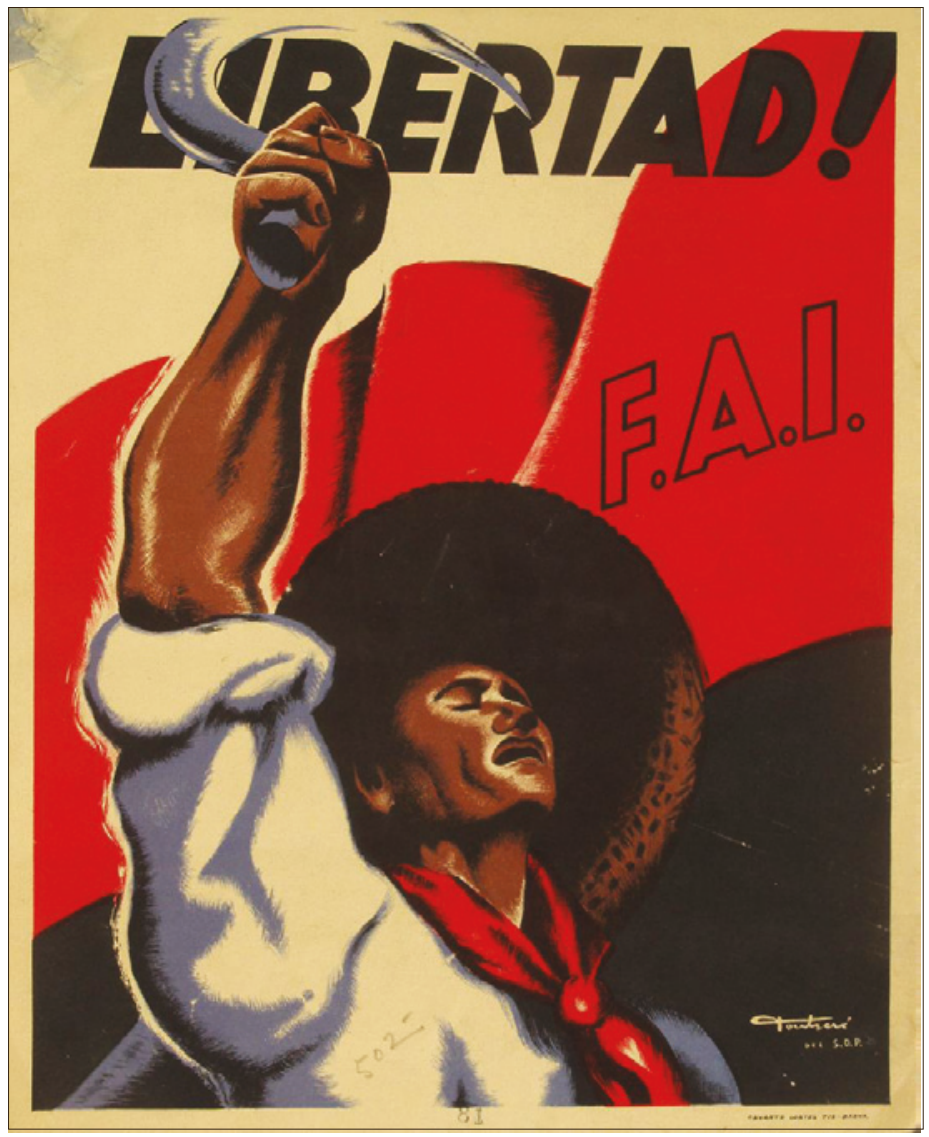

Guerra civil española. Autor: Bardasano (1910-1979)

Título: "Industria de guerra" 
Por lo que se refiere a la Escuela Bauhaus, su principio fundamental era: "La forma sigue a la función". Uno de sus principales planteamientos fue la aplicación de un diseño de calidad a los objetos de consumo con la finalidad de democratizar el buen gusto, antes únicamente reservado a las clases pudientes (Ver imagen pág. 29).

Las guerras de finales de la década de 1930 movilizaron a un gran número de creadores. Una de las manifestaciones de esa movilización son los carteles de la Guerra Civil Española, surgidos del activismo de un grupo de artistas y cartelistas que decidieron trabajar por la causa (Ver imagen pág. 30).

Durante la Segunda Guerra Mundial, en el año de 1945, surge en Rusia un movimiento similar y espontáneo: la propaganda y el cartel soviético de 1945, creando una vanguardia de arte político y revolucionario, donde se expresaba con mucho drama toda la situación bélica. Lázar Márkovich Lisitski (El Lisitski), es un gran representante de esta tendencia artística (Ver imagen pág. 33).

En la década del 60 también está la fuerte presencia del DG, representada por el diseñador británico Ken Garland, quien comenzó a trabajar a favor de la Campaña de Desarme Nuclear para la que realizó carteles tan conocidos como el titulado «Aldermaston to London Easter» (Ver imagen pág. 34), toda una referencia de la gráfica de protesta de esa época. Dos años más tarde, en 1964, publicó el manifiesto First Things First (Lo primero va primero) y consiguió el apoyo de unos cuatrocientos diseñadores y artistas, así como respaldo político. Fue publicado en The Guardian y fue invitado a la BBC TV a leerlo.

Se trataba de un llamado a los diseñadores del mundo a una mayor responsabilidad con las causas sociales, para que no trabajaran exclusivamente con la publicidad ya que así se estaba desperdiciando un talento valiosísimo que podría ponerse al servicio de causas mucho más útiles en otros soportes y espacios diferentes al medio publicitario de producto, como la señalización, la editorial educativa, publicaciones científicas, etc. 
A continuación la traducción del manifiesto:

"First Things First 1964

un manifesto:

Nosotros, los que firmamos, somos diseñadores gráficos, fotógrafos y estudiantes criados en un mundo en el que las técnicas y aparatos de publicidad se nos han presentado continuamente como la manera más lucrativa, efectiva y deseable de usar nuestros talentos. Se nos ha bombardeado con publicaciones devotas a esta creencia, aplaudiendo el trabajo de aquellos que han flagelado su habilidad eimaginación para vender cosas como: Comida para gato, polvos para el estómago, detergente, productos para la caída del pelo, pasta de dientes multicolor, loción para después de rasurarse, loción para antes de rasurarse, dietas para bajar de peso, dietas para subir de peso, desodorantes, agua carbonatada, cigarros, roll-ons, pull-ons y slip-ons.

El esfuerzo más grande de aquellos que trabajan en la industria de la publicidad se desperdicia en estos propósitos triviales, los cuales contribuyen poco o nada a nuestra prosperidad nacional. En común con el número creciente del público general, hemos alcanzado un punto de saturación donde el grito agudo de la venta al consumidor no es más que ruido. Creemos que hay cosas más importantes en las cuales podemos utilizar nuestra habilidad y experiencia. Existe señalización para las calles y edificios, libros y periódicos, catálogos, manuales de instrucciones, fotografía industrial, material educativo, películas, documentales televisivos, publicaciones científicas e industriales y todos los otros medios a través de los cuales podemos promover nuestro oficio, nuestra educación, nuestra cultura y nuestra consciencia del mundo.

No estamos a favor de la abolición de la publicidad de alta presión: esto no es posible. Tampoco queremos quitarle la diversión a la vida. Pero proponemos una reversión de las prioridades a favor de formas más útiles y perdurables de lacomunicación. Esperamos que nuestra sociedad se canse de vendedores pretenciosos y persuasivos, y que el requerimiento de nuestras habilidades sea para propósitos que valgan la pena. Con esto en mente proponemos compartir nuestra experiencia y opiniones, proporcionándolas a colegas, estudiantes y a otros a los que les pueda interesar." (Mackay, 2008) 


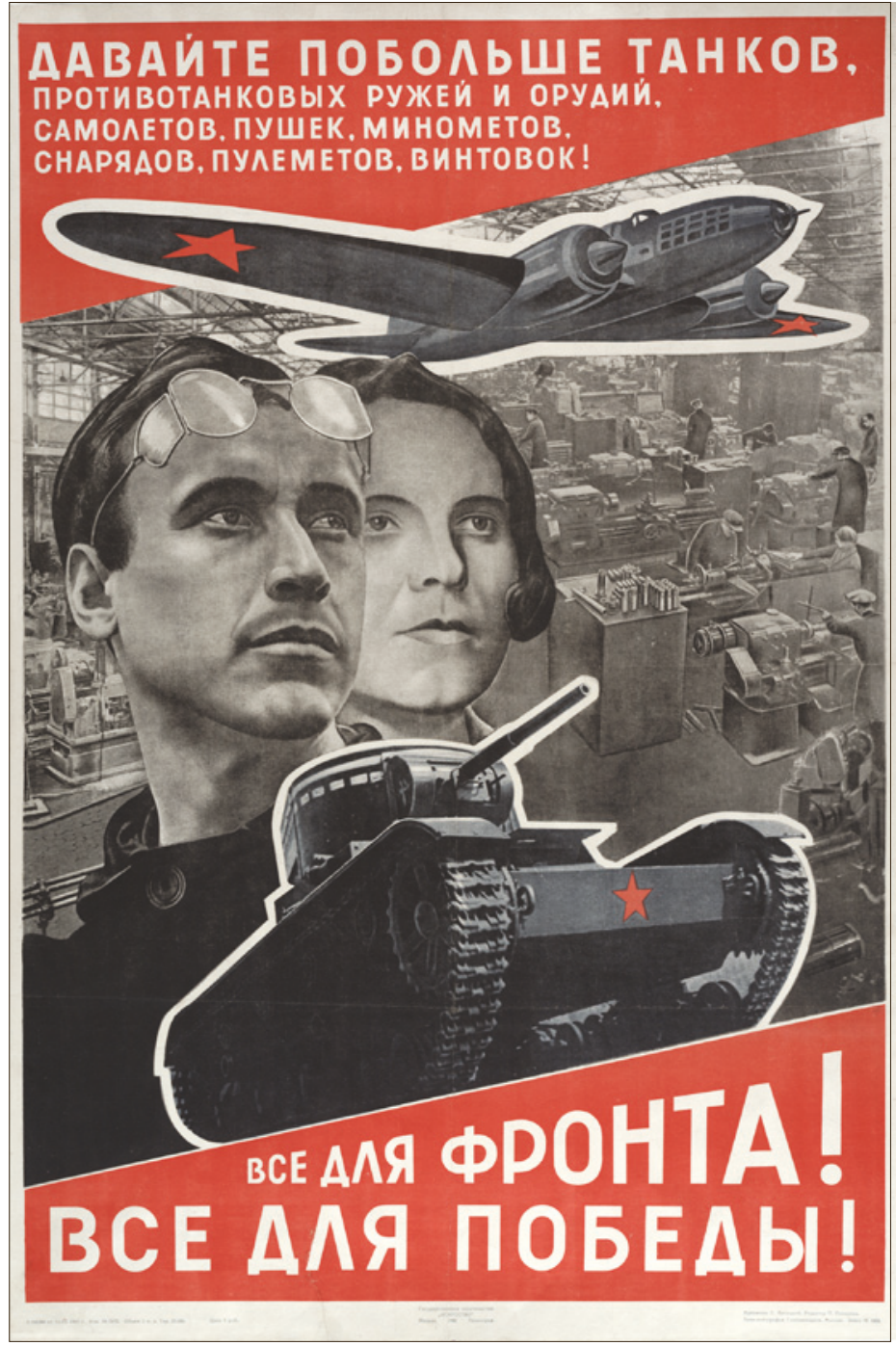

Propaganda rusa de posguerra.

“iTodo para el frente, todo para la victoria!" Autor: Lázar Márkovich Lisitski (El Lisitski), 1945 


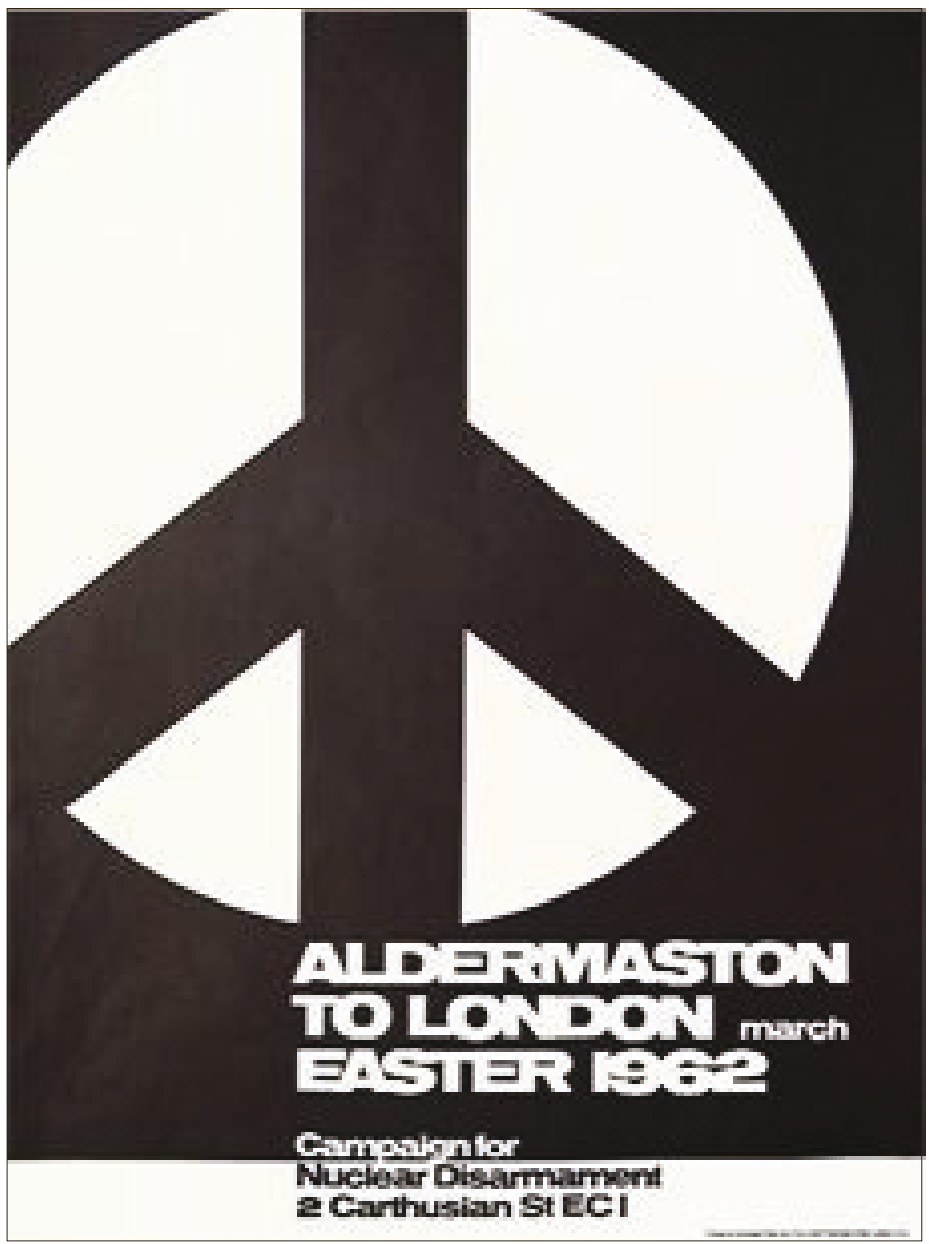

Campaña para desarme nuclear. Autor: Ken Garland

Título: "Aldermaston to London Easter", 1962 
En el ámbito político, los nuevos grupos (hipismo, feminismo, etc) buscaban cambios globales en la escala de valores con el fin de alterar el sistema con objetivos sociales determinantes, grupos que fueron fuertemente identificados con imágenes visuales que aún hoy en día son reconocidas.

En el contexto latinoamericano, señalo lo que menciona José Luis Romero:

“(...) lo más singular en el proceso de formación de las corrientes de opinión en Latinoamérica es la constitución espontánea de movimientos populares de fuerte contenido emocional y difusa significación ideológica. ( )Esta circunstancia dio a tales movimientos una fuerza singular -una fuerza telúrica, se ha dicho alguna vez- y una extraordinaria capacidad de aglutinación" (Romero, 1967)

Fuerza de la cual surgieron movimientos insurreccionales, como el de Sandino en Nicaragua, la revolución mexicana de 1910 (Ver imagen pág. 37) y la revolución cubana finalizando la década del 50, causando transformaciones profundas en las sociedades de cada país, en todos los aspectos.

Específicamente en Cuba, el 1 de Enero de 1959 la revolución triunfa dando lugar así al establecimiento de un nuevo gobierno socialista en la isla comandado por Fidel Castro, quien estaba influenciado directamente por Lenin, Engels y Marx. El marxismo, precisamente como la matriz de pensamiento más difundida entre los 60 y los 80 en América Latina desde las universidades públicas, influenció directamente a la comunicación visual, y de allí surgieron expresiones que eran reflejo claro de ese entorno, como el resultado de un orden histórico-social inherente a la comunicación (Ver imagen pág. 38).

La sociedad y la economía, paralelas a la comunicación social estuvieron desde luego afectadas por esos cambios, que dieron una perspectiva radicalmente diferente al DG. Cuba venía de una época donde se habían instalado bastantes agencias de publicidad bajo un modelo norteamericano, por ello esta nueva etapa estaba llena de diseñadores muy entrenados en su oficio. 
Así surgieron nuevos emisores de la comunicación, cambiaron los mensajes, y los receptores dejaron de ser potenciales consumidores para convertirse en destinatarios de mensajes políticos, sociales, educativos y culturales. Esto tiene relación con la crisis de pensamiento de los años 70, cuando aparece una redefinición de la historia de las ideas como exploración de lo mental colectivo y comienzan a cambiar los conceptos entendiéndose que las ideas situadas en sus raíces sociales se convierten en fuerzas colectivas. No se trata de enumerar ideas, palabras o pensamientos, sino de entender las formas en las que un individuo o grupo se apropia de un motivo intelectual o una forma cultural. (Romero, 1967)

Los conceptos "culto" y "popular" se modifican en el sentido de que se entienden como una mezcla donde se incorporan elementos, ya que de la creación, consumo, producción y recepción de lo cultural o intelectual no resulta un producto concreto sino que constituye representaciones diferentes a sus orígenes. Se podría decir que se abandonaron las tentativas de teorías generales y apareció la necesidad de incitar el pensamiento hacia una actitud más crítica en lo cotidiano, entendiéndose la importancia fundamental de la democracia para el desarrollo de nuestras sociedades.

El académico Erick Torrico destaca:

“(...) la Comunicología de Liberación propuesta por el boliviano Luis Ramiro Beltrán en 1976 puede ser considerada entre las fuentes del pensamiento decolonial junto a otras elaboraciones del dependentismo y el anticolonialismo latinoamericano de entonces. El programa de investigación de modernidad/colonialidad, matriz académica de ese pensamiento, expresa desde mediados de los años $\square 90$ la renovación que vive el pensamiento crítico latinoamericano, movimiento que tensiona los conceptos hasta ahora aplicados para dar cuenta de los procesos sociales de la región tanto como sus presupuestos, aparte de que se orienta a la conformación de un "paradigma otro" que se desmarque de la visión eurocéntrica prevaleciente desde el siglo XIX. La Comunicación posee bases suficientes para participar en estos desarrollos". (Torrico, 2010) 

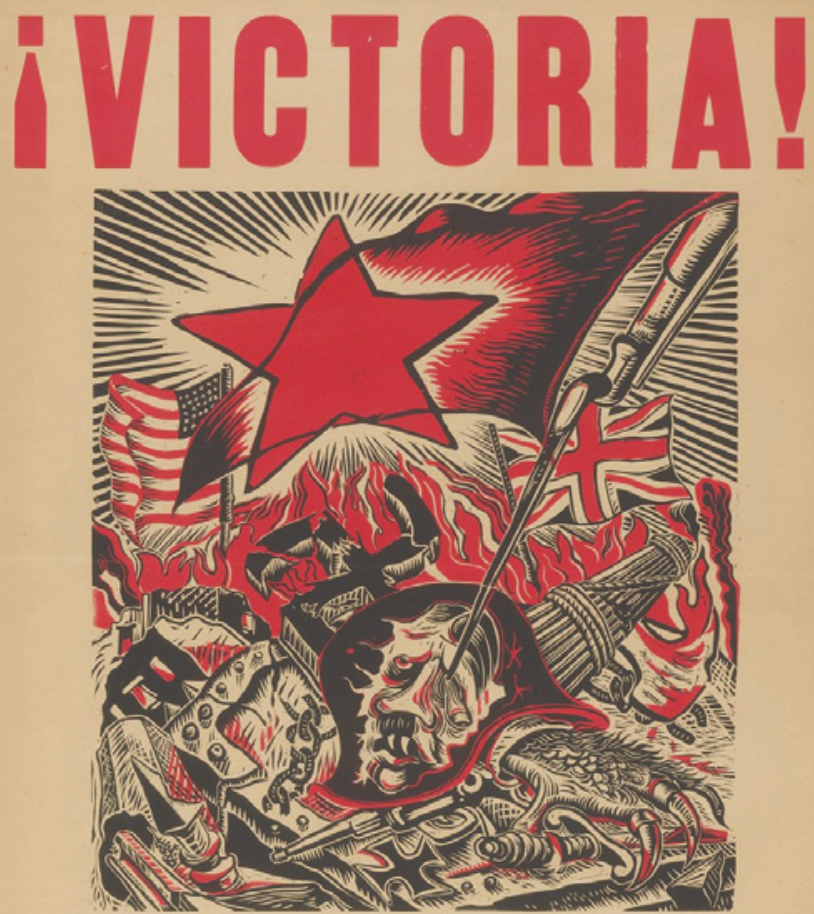

Los artistas del Taller de Gráfica Popular nos unimos al júbilo de todos los trabajadores y hombres progresistas de México y del Mundo por el triunfo del glorioso Ejército Rojo y de las armas de todas las Naciones Unidas sobre la Alemania Nazi, como el paso más trascendente para la

Autor: Ángel Bracho, Taller de Gráfica Popular. Título: “Victoria!", 1945 

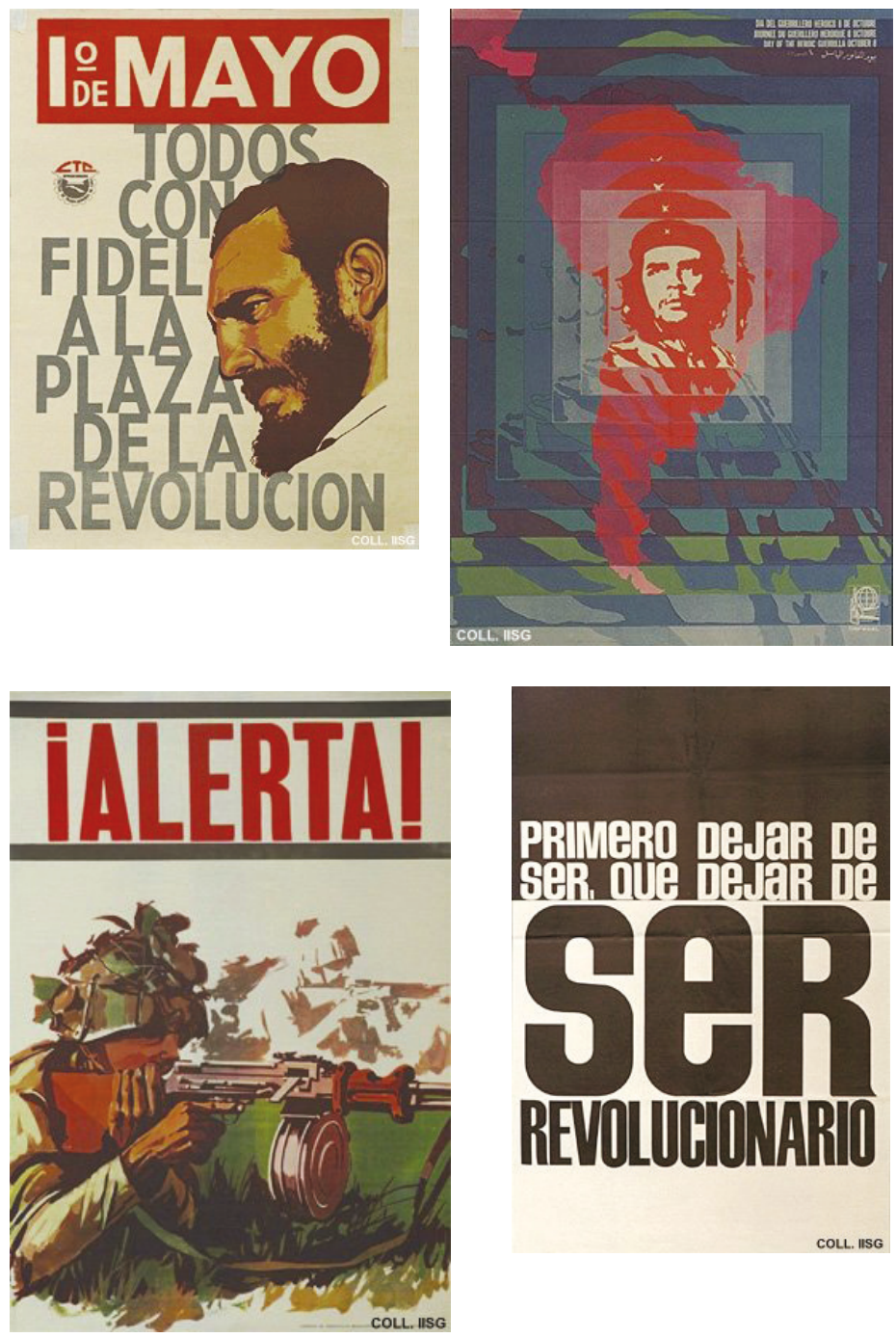

El cartel en la Revolución Cubana

Autores varios, años 60 


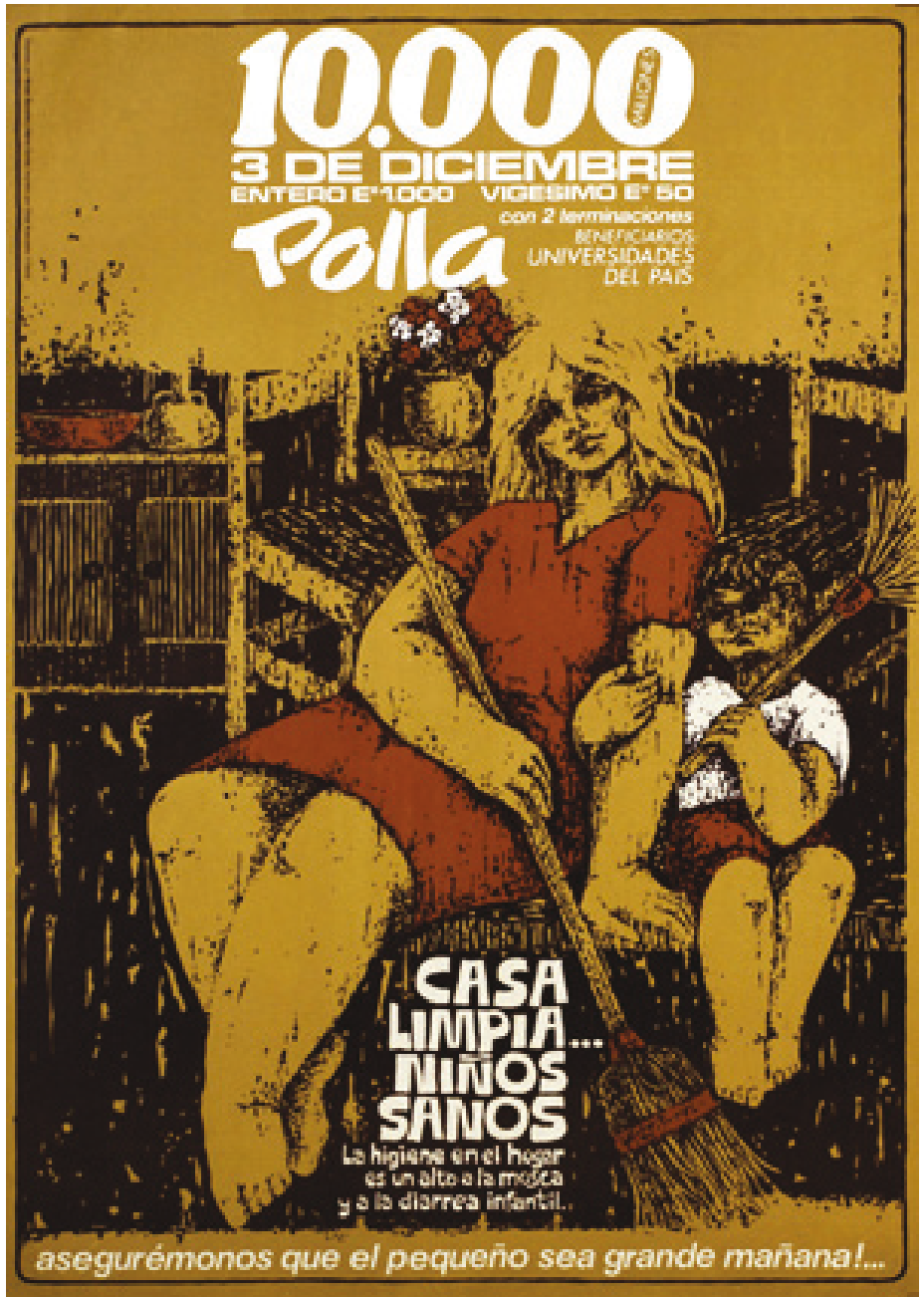

El cartel político en Chile Autores: Waldo González y Mario Quiroz, 1972 


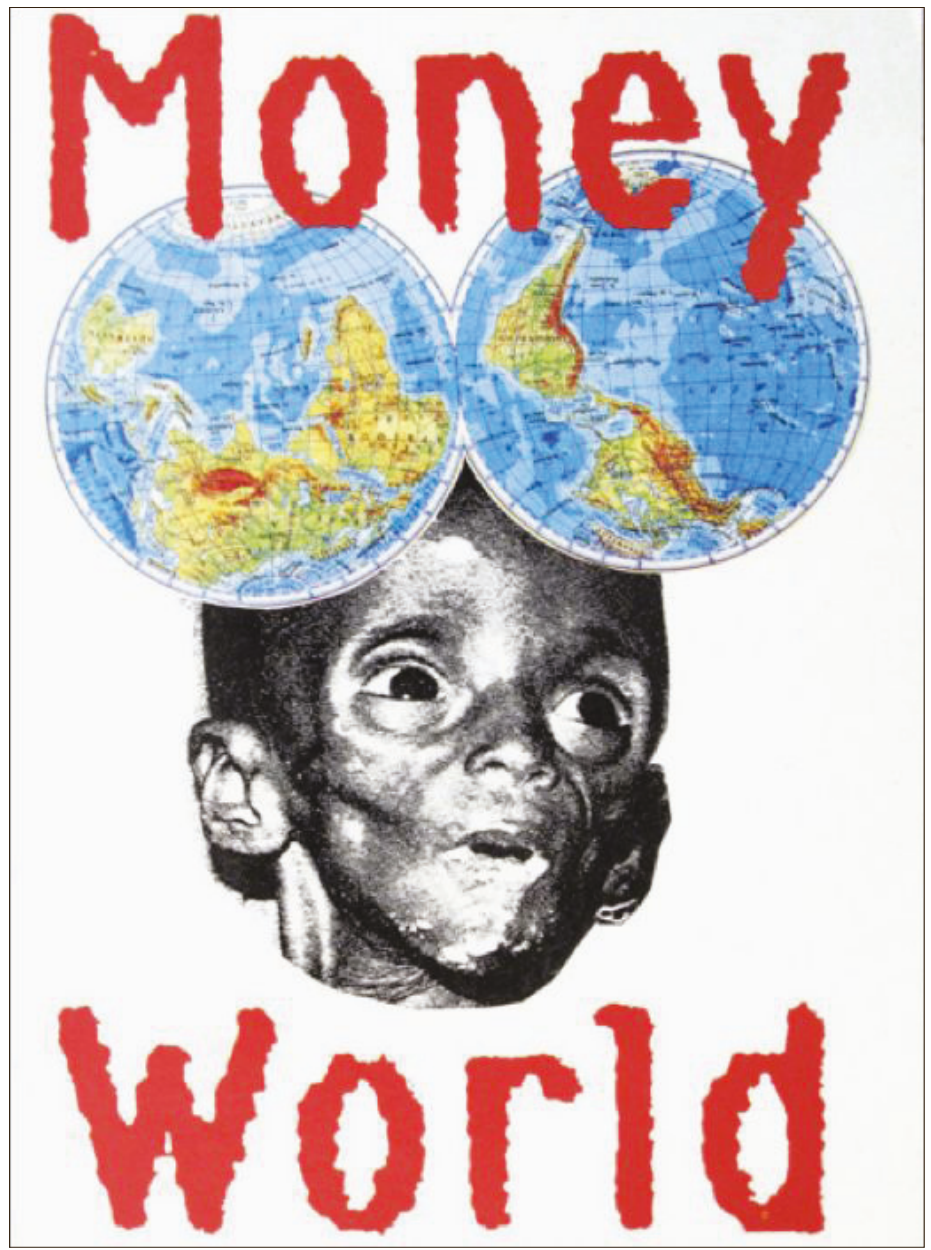

Gráfica activista en Francia.

Autor: Grapus. Título: "Money-World", 1989 
El diseño en tanto comunicación no fue ajeno a esas transformaciones, dado que en la misma década, comenzó a surgir un sentimiento activista a través del concepto de diseño alternativo, expresado por diseñadores que se encontraban fuera de movimientos, agrupaciones o partidos y que fue en aumento durante la primera década de este siglo, tomando en cuenta temas relacionados con el medio ambiente, la paz, la globalización, la protección a la niñez y cuestiones de profundo interés mundial, demostrando un compromiso individual con la realidad del planeta.

En Latinoamérica, paralelo a la Comunicología de la Liberación como respuesta a la perspectiva de la Invasión Cultural en la en los años 70, es como poco a poco se ha instaurado el concepto de el/la diseñador/a comprometido/a con lo social, dejando de ser sencillamente el/a transmisor/a de mensajes para pasar a tener una posición propia y responsable desde el momento que asume el diseño de un objeto nuevo.

En Chile surgió un fenómeno de cartel político comandado por la izquierda que comenzó a aparecer a fines de la década de 1960. Tuvo una primera etapa con los que fueron realizados para la campaña presidencial de Allende, finalizando con el triunfo de éste en septiembre de 1970 (Ver página 39). Una segunda parte, posterior al ascenso al poder de la UP, en la que este cartel se desarrolló y alcanzó una renovación de sus códigos estilísticos y mensajes. (Vico, Monográfica, 2011)

Por otro lado y para no perder de vista el resto del planeta, debo referenciar aquí a Gérard Paris Clavel, fundador de Grapus, colectivo francés de Diseño Gráfico (1968-1990) que marcó época en la gráfica mundial (Ver página 40). En sus 20 años de duración trazaron un estilo con ironía y humor, en el uso de lo manual, como la tipografía manuscrita, por ejemplo -hecha con pincel, a veces hasta con los dedos-. A eso le sumaron la combinación creativa de recursos gráficos, el montaje, el collage, el dibujo, la fotografía, la pintura; y, sobre todo, el empleo del simbolismo y de una tónica irreverente. 
“Durante unos veinte años -su disolución se producirá en enero de 1991, tras haber recibido el Gran Premio Nacional de Arte Gráfico de Francia- Grapus diseñó campañas sociopolíticas impactantes (...); creó la imagen corporativa del sindicato comunista CGT y desarrolló la línea de comunicación de un buen número de organizaciones de ayuda humanitaria, centros culturales (...), teatros (...) y museos (...); agrupó a diseñadores reconocidos de todo el mundo para llevar a cabo proyectos en torno a una determinada causa (...); mostró su trabajo en más de cincuenta exposiciones y provocó, en su momento, una buena cantidad de literatura.". (Design Thinks)

En el marco del ciclo de conferencias "La formación del diseñador y la práctica profesional", realizado en Buenos Aires en 1997 con motivo del $10^{\circ}$ aniversario de la revista tipoGráfica, ante la pregunta formulada por los origanizadores en una mesa redonda: ¿Cree que es posible una campaña para cambiar la opinión pública en una sociedad tan individualista como la de este país?", respondió: "Yo creo que son las campañas basadas en un modelo publicitario las que cambian la opinión de la gente porque solo sirven para crear reflejos condicionados. Son las relaciones duraderas que se dan en el seno de prácticas de intercambio las que pueden modificar las opiniones". (Clavel, 1997)

En el mismo evento, cuando se le consulta ¿Por qué la imagen de Benetton le parece nefasta?, responde:

“(...) Cuando (Benetton) muestra la imagen de un bebé recién nacido recortada sobre un fondo blanco con el cordón umbilical aún formando parte de su cuerpo, lo expone como un producto. No muestra ni a las personas que asistieron a la madre en el parto ni al padre. Lo recorta como un producto único fuera de todo mundo real. Benetton transforma al mundo en un producto espectacular, valorizando así su marca. Para juzgar si Benetton es un humanista o no sería interesante saber si deslocaliza su fabricación textil, cuánto les paga a sus obreros y si hace trabajar a los niños en Asia". (Clavel, 1997) (Ver página 43)

En Estados Unidos, en la década del 80, es destacable la fundación en Nueva York del grupo de activistas ACT UP (AIDS Coalition to Unleash Power - Coalición del sida para desatar el poder). 


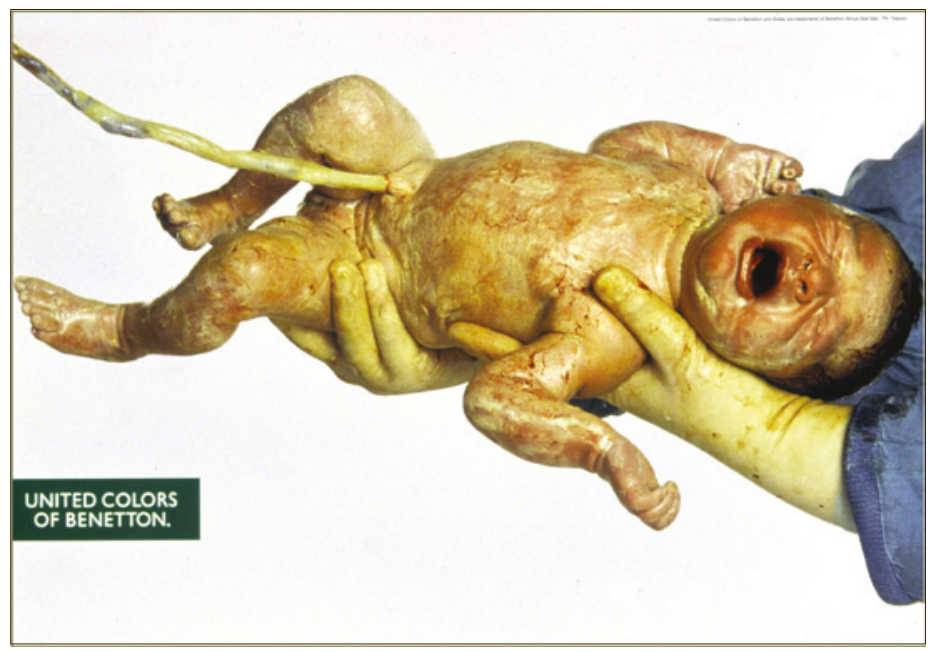

Publicidad de Benetton

Autor: Oliviero Toscani, 1991 
REDISEÑANDO MUNDOS

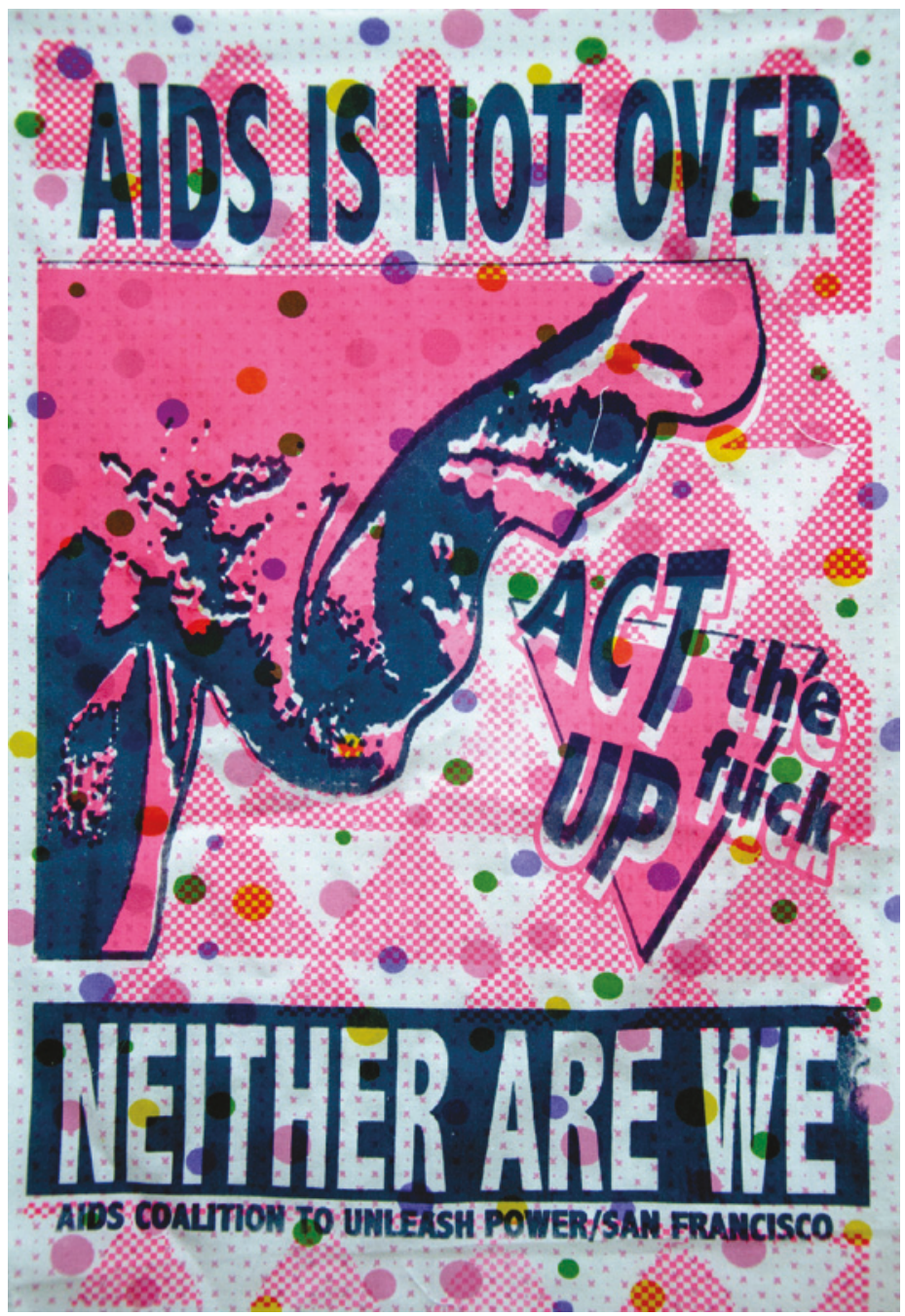

Campaña ACT UP, 1988 
Nacido con el objetivo de combatir la pasividad gubernamental estadounidense en relación al SIDA, en aquellos años tema totalmente tabú. ACT UP representó a finales de los 1980, un paso importante hacia el diseño como herramienta de expresión política. Desde sus comienzos, esta organización se ha destacado por una estrategia interesante: se ha apropiado del lenguaje visual de las empresas y de la publicidad para utilizarlo como instrumento contra las instituciones de poder pues su intención ha sido siempre cambiar las actitudes y comportamientos «oficiales» ante determinadas situaciones. En ese sentido han explorado las posibilidades que ofrecía dicho lenguaje, trabajando con la sofisticación de la mejor de las agencias publicitarias y recurriendo a todos los medios posibles: desde vallas hasta productos de mercadeo (Ver página 44).

En el año 2000 apareció en Canadá una actualización del manifiesto First things First de 1964, teniendo en cuenta la época y los avances tecnológicos. La revista Adbusters y otras seis diferentes (Blueprint, AIGA journal, Eye, Items, Form, Emigre) lo apoyaron.

Se presentó de la siguiente forma (traducción):

«Nosotros, los abajo firmantes, somos diseñadores gráficos, fotógrafos y comunicadores visuales que nos hemos criado en un mundo en el cual las técnicas publicitarias y sus medios se nos han presentado de manera insistente como el lugar más lucrativo, más eficiente y deseable donde utilizar nuestros talentos. Muchos profesores de diseño y mentores promueven esta creencia; el mercado la premia; una marea de libros y publicaciones la refuerza.

Animados en esta dirección, los diseñadores entonces aplican su destreza e imaginación a vender galletas para perros, café del diseñador, diamantes, detergentes, gomina para el pelo, cigarrillos, tarjetas de crédito, zapatillas, tónicos, cerveza sin alcohol y vehículos todoterreno. El trabajo comercial ha pagado siempre las cuentas, pero muchos diseñadores gráficos no han permitido que se convirtiera en gran parte de lo que hacen. Esta es, en cambio, la manera en que el mundo percibe el diseño. El tiempo y la energía profesionales se usan para atender la demanda de cosas que, a lo mejor, no son esenciales. 
Muchos de nosotros nos hemos sentido cada vez más incómodos con esta visión del diseño. Los diseñadores que dedican sus esfuerzos ante todo a la publicidad, el marketing y el desarrollo de la marca están apoyando, e implícitamente respaldando, a un ambiente mental tan saturado con mensajes comerciales que está cambiando por completo el modo en que los ciudadanos-consumidores hablan, piensan, sienten, responden e interactúan. Hasta cierto punto estamos ayudando a elaborar un código enormemente dañino para el discurso público.

Hay actividades más valiosas para nuestras habilidades de resolución de problemas. Una crisis ambiental, social y cultural sin precedentes demanda nuestra atención. Muchas intervenciones culturales, campañas de marketing social, libros, revistas, exposiciones, herramientas educativas, programas de televisión, películas, causas caritativas, y otra información -proyectos de diseño- requieren urgentemente nuestra experiencia y ayuda.

Proponemos un cambio de prioridades a favor de unas formas de comunicación más útiles, perdurables y democráticas, un cambio de mentalidad que se aleje del marketing de producto y se dirija hacia la exploración y producción de un nuevo tipo de significado. El alcance del debate está reduciéndose; debe expandirse. El consumismo está avanzando sin oposición; debe desafiarse con otras perspectivas expresadas, en parte, a través de los lenguajes visuales y los recursos del diseño.

En 1964, veintidós comunicadores visuales firmaron la llamada original para que nuestras capacidades se dedicaran a un uso más valioso. Con el crecimiento explosivo de nuestra cultura comercial global, su mensaje ha llegado a ser más urgente. Hoy, renovamos su manifiesto a la espera de que no pasarán más décadas sin tomarlo en serio.» (Otoño de 1999). (Pelta, Manifiesto First Things First 2000, 2012)

El DG ha estado presente en importantes eventos relacionados con acciones en contra del sistema consumista, donde un gran número de diseñadores/as han visto en el oficio una excelente herramienta de transformación.

“En la historia reciente se ha exteriorizado como una profesión fundamental, a través de una cierta consciencia renovada sobre su poder y la construcción de un discurso sobre el diseño como 
el instrumento para dar forma a la realidad, desde sus ambientes, objetos, espacios, imágenes y mensajes, con una proyección que va más allá de diseñar para campañas ambientalistas o derechos humanos, sino que apunta a re-configurar la estructura de las mentes de los diseñadores" (Frascara, 1997).

De ahí la importancia de trabajar en la enseñanza de una dimensión socio-política de un DG no invasivo, sino en aquel que exista para defender los principios de una sociedad en equilibrio, donde no existan preferencias para unos cuantos, sino que al contrario, esté al servicio de todos. Desde este punto de vista, de el/la diseñador/a depende en qué enfoca sus capacidades, si en crear necesidades inventadas, o en responder a las necesidades reales de cada persona.

Pero, ¿cómo se re-configuraría la mente de un/a diseñador/a gráfico/a? Lejos estoy de tener una respuesta que solucione esta pregunta en toda su extensión, sin embargo me atrevo a considerar que un punto de partida importante sería re-configurar inicialmente el concepto de lo que se enseña como DG. 


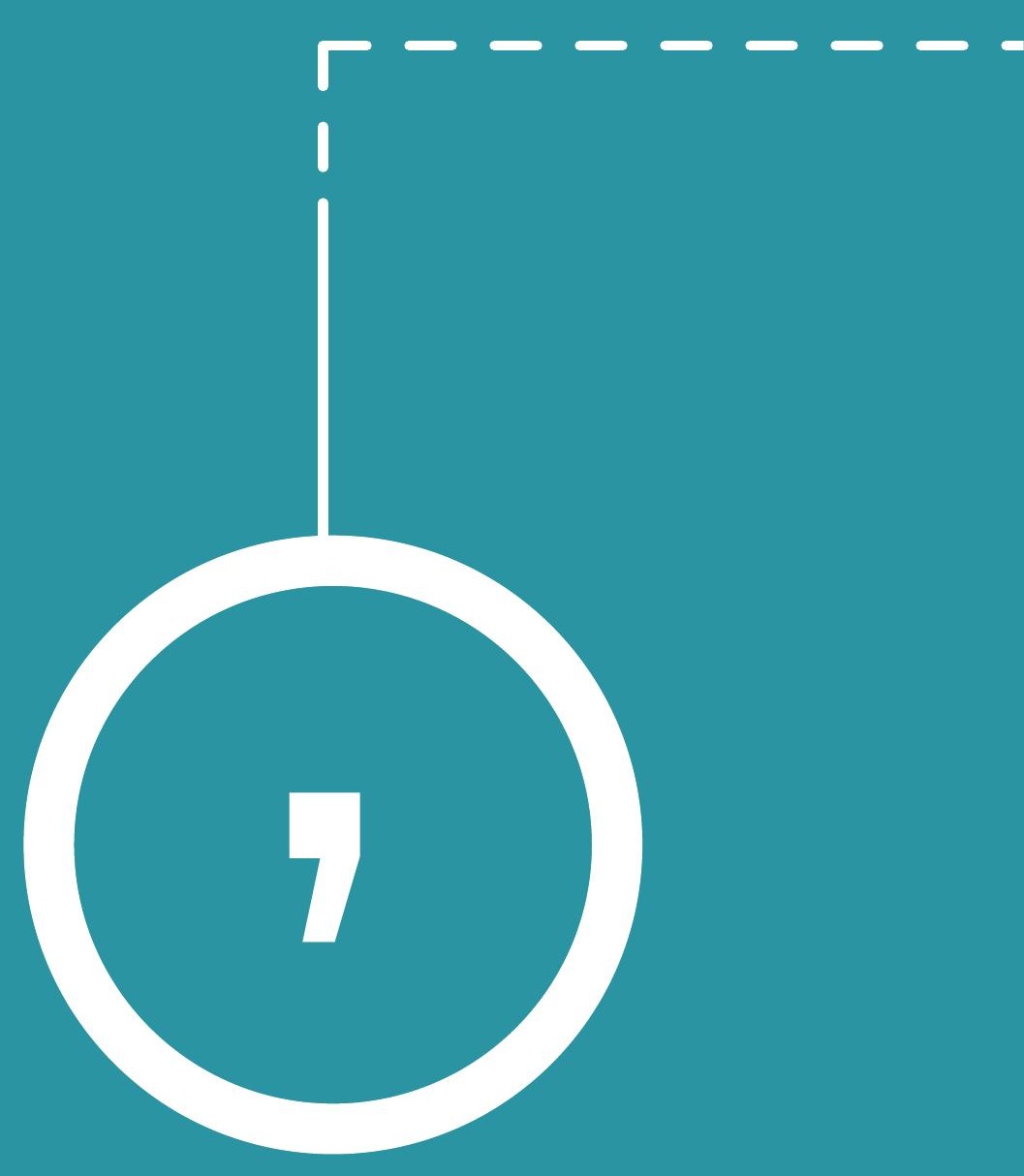




\section{DISEÑO GRÁFICO CON CONSCIENCIA SOCIAL: CULIURAL, POLIITCOC, DEMOCRÁIICO, RESPONSABLE, PARTICIPATIVO Y ECONÓMICO}

Sin el ánimo de cuestionar las diferentes definiciones que existen sobre el DG, lo cual se aleja de los objetivos de esta tesis, me interesa resaltar algunos aspectos que se me han revelado con mi trabajo de investigación en esta maestría y considero de vital importancia, ya que le han dado un giro a mi concepción de la profesión y creo firmemente que esa noción puede y debe ser difundida desde diferentes lugares para que como a mi, a muchos diseñadores y diseñadoras se les revelen caminos antes no imaginados.

\subsection{Diseño Gráfico, práctica cultural}

Yendo al origen de esta perspectiva, diferentes autores allanaron el camino que me llevaría a ver mi profesión de esta manera. Desde Bordieu, pasando por García Canclini, Mattelart y Jesús Martín Barbero, entre otros, tuve la oportunidad de pensar y entender lo que la cultura es y significa para una sociedad. Nuevamente, este para mi representa otro de los olvidos teóricos (Devalle, 2009) presentes en el estudio del Diseño Gráfico como carrera profesional, por lo menos visto desde mi experiencia.

Dice García Canclini en la introducción de Sociología y Cultura:

"En uno de sus primeros textos, Campo intelectual y proyecto creador, Bordieu observa que "para dar su objeto 
propio a la sociología de la creación intelectual" hay que situar al artista y su obra en el sistema de relaciones constituido por los agentes sociales directamente vinculados con la producción y comunicación de la obra. Este sistema de relaciones, que incluye artistas, editores, marchantes, críticos, público, que determina las condiciones específicas de producción y circulación de sus productos, es el campo cultural". (Bourdieu, 1990).

Entendido así, Bordieu estudia el tema de cultura desde el punto de vista del "gusto" porque se centra en el arte, yo traslado esto al DG tomando ese concepto de "gusto" como preferencias de los grupos y sociedades donde se practique el diseño, estudio del contexto, factor q se debe tener en cuenta a la hora de diseñar y comunicar.

De la misma forma, para comunicar, para construir sentidos con el DG, este no debe ser autoreferenciante, o por lo menos no sólo así, requiere nutrirse del público y retroalimentarse de las personas que lo ven, lo perciben y lo usan, de otra forma sería una especie de "Estética incestuosa: el arte por el arte es un arte para los artistas" (Bourdieu, 1990). El DG no debe ser para diseñadores/ as, debe ser para las personas, para las sociedades, para el público.

El DG está presente de forma permanente en las maneras de comunicar dentro de las sociedades, la imagen lo abarca todo, y esto ha sido dado por el creciente y rápido avance de la globalización,

“(...) la globalización pone en marcha un proceso de interconexión a nivel mundial, que conecta todo lo que instrumentalmente vale -empresas, instituciones, individuos- al mismo tiempo que desconecta todo lo que no vale para esa razón. Este proceso de inclusión/exclusión a escala planetaria está convirtiendo a la cultura en espacio estratégico de compresión de las tensiones que desgarran y recomponen el Øestar juntos $\square$, y en lugar de anudamiento de todas sus crisis políticas, económicas, religiosas, étnicas, estéticas y sexuales. (...) Si la revolución tecnológica ha dejado de ser una cuestión de medios, para pasar a ser decididamente una cuestión de fines, es porque estamos ante la configuración de un ecosistema comunicativo conformado no sólo por nuevas máquinas o medios, sino por 
nuevos lenguajes, sensibilidades, saberes y escrituras, por la hegemonía de la experiencia audiovisual sobre la tipográfica, y por la reintegración de la imagen al campo de la producción del conocimiento". (Barbero, 2002)

En medio de ese proceso de globalización, las costumbres y actividades de las personas están siempre tocadas por algún aspecto del DG, un ejemplo claro lo obtengo citando nuevamente a Barbero "De ahí que el éxito de McDonald's o de Pizza Hut hable, más que de la imposición de la comida norteamericana, de los profundos cambios en la vida cotidiana de la gente, cambios que esos productos sin duda expresan y rentabilizan". (Barbero, 2002)

Y más allá, la manera en que el DG interviene comunicando construye identidad dentro de las sociedades, identidad que también se ha venido transformando junto con la cultura, identidad desde el punto de vista de raíz y territorio y también desde la redes, movimiento, diversidad, migración y desanclaje. (Barbero, 2002)

Más allá de acercarme a estos conceptos traidos de la sociología y la comunicación, para mi ha sido un descubrimiento emocionante encontrarme con tan diversos materiales académicos que tocan el tema del DG como un saber, más allá de verlo como un oficio práctico cuya única finalidad es la obtención de un objeto gráfico, sea este impreso, digital o virtual.

Dentro de esos hallazgos de los cuales afortunadamente ya no me puedo separar, está el trabajo teórico de Verónica Devalle, socióloga y doctora en artes que trabaja como docente en la carrera de DG en la Universidad de Buenos Aires. En su trabajo ella muestra que al:

“(...) comprender al Diseño Gráfico como "práctica cultural" realizamos una lectura atenta a su participación en la construcción de la hegemonía social. Debemos por lo tanto aclarar que aunque el Diseño Gráfico no participe de un reconocimiento temático como área privilegiada de la cultura, el tipo de acciones que produce, así como las superficies sobre las que trabaja, nos sugiere su creciente importancia. Podemos adelantar que si entendemos que el Arte fue y es una práctica significante (donde podemos "leer" los aspectos más significativos de una cultura), 
el Diseño Gráfico es factible de una identificación homóloga, que revele -a la vez- su condición de práctica hegemónica. Esta razón nos invita a considerarlo un fuerte indicador de nuestra actual formación cultural, aquella que privilegia temáticamente a la imagen y que tramita modelos visuales de identificación, patrones de gustos y fenómenos -masivos- de adscripción afectiva a determinados productos". (Devalle, 2009)

Ella aborda el DG como una disciplina y una profesión moderna, entendiéndola como un diálogo activo con una determinada sociedad. "Un diálogo que ( ) siempre va a marcar una conexión vital, y por lo tanto situada con las diversas esferas de lo social, sea económica, cultural o política". (Devalle, 2009)

Si se lograra mirar la profesión desde esta perspectiva, la dimension comunicacional saldría a flote naturalmente, sería claramente un diálogo de la imagen para crear sentidos. Ya no más un oficio instrumental para producir objetos. Y desde esa dimensión aparecerían por orden lógico lo democrático, lo participativo, lo responsable y claramente, la dimensión social y política. Esto último entendido como el aspecto que involucra y tiene en cuenta primero a las personas y a las ideologías antes que a los objetos, o a cualquier otro elemento que distraiga de las necesidades y deseos de ellas.

\subsection{La dimensión socio-política del Diseño Gráfico}

Desde hace algunos años el Ilamado aspecto social del DG ha sido suceptible de muchos debates donde aparece como núcleo la función social del diseño. Para aclarar un poco este tema, me remito a un artículo publicado hace varios años por Guillermo Brea ${ }^{8}$ :

8. Diseñador gráfico y docente especialista en Identidad visual y comunicación institucional, con 26 años de trayectoria. Ejerce la docencia en la carrera de Diseño Gráfico en la Universidad de Buenos Aires. 
"Conviene no confundir lógica social de la profesión con causas sociales (sean del signo ideológico que fueren). Carecemos aquí del espacio para profundizar en el tema, pero si la cuestión va a debatirse seriamente es necesario diferenciar algunos términos como fines, valores, moral, ética, deontología, axiología y teleología, que no significan todos lo mismo. Forzar la cuestión a una dilematización entre Exxon o las Madres de Plaza de Mayo es minimizarla, como lo son también optar entre «diseñar o hacerse cartonero» y «hacer trabajos divertidos o los encargos aburridos del mercado». Pensar estas cuestiones desde un presunto «adentro» $\mathrm{o}$ «afuera», en una suerte de apocalípticos o integrados es una simplificación: el campo social es un territorio más complejo que una cancha de tenis con los mercaderes de un lado y los «buenos ciudadanos» del otro" (Brea, 2005).

Y es que además de los diseñadores y diseñadoras interesados en trabajar en favor de soluciones a los problemas sociales del mundo, han surgido profesionales que consideran que además de los mensajes que se transmiten, el/la diseñador/a debe establecer nuevos límites para el diseño y optan por lo que se ha denominado «Diseño para todos» o «Diseño Universal». Término que fue acuñado por Ronald L. Mace (1941-1998), arquitecto, diseñador de productos y docente de la Universidad de Carolina del Norte en Estados Unidos ${ }^{9}$.

Desde el Diseño Industrial, han surgido perspectivas de trabajo importantes para el DG, ya que el resultado final de su proceso no deja de ser un objeto, en su caso uno impreso o digital.

Victor Papanek, diseñador y antropólogo austriaco, autor del libro Design for the Real World. Human Ecology and Social Change $^{10}$, publicado a inicios de la década del 80 , es considerado uno de los primeros diseñadores industriales preocupados por las

9. Fundador del Centro de Diseño Universal. Pionero y visionario reconocido internacionalmente cuya filosofía de diseño desafió convenciones y proporcionó las bases del diseño para un mundo más usable. Acuñó el término "diseño universal" para describir el concepto de diseño de todos los productos y el entorno construido para ser estético y utilizable en la mayor medida posible por todo el mundo, independientemente de su edad, capacidad, o estatus en la vida. También fue un defensor dedicado a los derechos de las personas con discapacidad lo cual se refleja a lo largo de su obra.

10. Diseño para el Mundo Real. Ecología Humana y Cambio Social. 
consecuencias que la práctica de su profesión puede tener en la ecología y los recursos naturales. Sostiene que si el diseñador/a es consciente y controla variados factores, entre ellos los límites de la producción, podría ejercer su oficio para mucha gente y no solo para unos pocos privilegiados. (Papanek, 1984)

El Diseño Universal, es toda una filosofía pues se trata de un proceso de diseño orientado a crear productos y entornos de fácil uso, utilizables por el mayor número de personas, abarcando el mayor tipo de situaciones posible -siempre que puedan comercializarse-sin la necesidad de adaptarlos o rediseñarlos de una forma especial, justamente para evitar crear objetos sin sentido totalmente innecesarios en el mundo. (The Center for Universal Design). Esto no es nada más que un diseño participativo y democrático completamente aplicable al DG.

Más recientemente surgió el Ilamado Design Thinking, una metodología para generar ideas innovadoras nacida también desde el Diseño Industrial, pero muy extendida ya a los demás enfoques del diseño, que centra su eficacia en entender y dar solución a las necesidades reales de los usuarios. Su nombre en español se traduce de forma literal como "Pensamiento de Diseño". Se empezó a desarrollar de forma teórica en la Universidad de Stanford en California (EEUU) a partir de los años 70, y su primera aplicabilidad con fines lucrativos como "Design Thinking" la llevó a cabo Tim Brown, profesor de la escuela de Ingeniería de Stanford University y CEO y presidente de IDEO. Según él, el Design Thinking "Es una disciplina que usa la sensibilidad y métodos de los diseñadores para hacer coincidir las necesidades de las personas con lo que es tecnológicamente factible y con lo que una estrategia viable de negocios puede convertir en valor para el cliente, así como en una gran oportunidad para el mercado". (Design Thinking en Español)

Es así como en este proceso de investigación, he podido descubrir cómo desde diferentes lugares y contextos, han venido surgiendo desde hace algunos años, incluso décadas, nuevas perspectivas en el mundo del diseño en general, las cuales tocan directamente al DG. 
Algunas de estas prácticas se concentran específicamente en el DG con objetivos sociales, es decir, en beneficiar a las personas por encima del mercado, tomando responsabilidad sobre el mensaje que se va a comunicar con imágenes, compartiendo ideologías y pensamientos con quienes hacen el llamado para trabajar (los clientes, por no tener aún una palabra más acorde que los defina), siendo así también un diseño político, haciendo consciencia del no ser indiferente ante esos mensajes.

Otras tienen como objetivo primordial cuidar y preservar el medio ambiente, por ello tienen en cuenta los materiales y procesos de producción, la cantidad de objetos a producir y el destino que el público les dará cuando lleguen al fin de su vida útil. Otras de estas prácticas se preocupan ante todo por que el DG se convierta en un derecho y en un bien público, que cualquier organización y/o persona tenga acceso a estos servicios de DG, que sean de alta calidad y que cumplan su función de llevar a cabo sus objetivos organizacionales y de comunicación, tanto interna como externamente.

En esta tesis, me quiero referir a un diseño que fusiona todos esos conceptos. Me refiero a un Diseño con Consciencia Social, practicado por un/a diseñador/a que analiza y se preocupa por el qué y cómo de los mensajes que transmite y de los cuales se producirán nuevos sentidos en el público, también se siente responsable de la forma que le dará al objeto que será producido, los materiales y procesos que se usarán para realizarlo y sus consecuencias para la sociedad, a la vez que enfrenta la solución de problemas como un derecho ciudadano, haciendo lo posible por encontrar el camino para acercarse a quien requiera de esos servicios profesionales y llevar sus objetivos a cabo.

Todo ello sin perder de vista lo que menciona María Ledesma:

“Es posible pensar en un diseño que ni se engañe con sus posibilidades revolucionarias, ni se rinda frente a las demandas del narcisismo contemporáneo, ni se obnubile detrás de los cantos de sirenas detrás de las eficacias comunicacionales y que sin embargo, siga siendo diseño gráfico". (Ledesma, 2010) 
Desde esta perspectiva, el DG se concibe como un factor que contribuye a institucionalizar las prácticas sociales y también a cuestionarlas.

"En este sentido, el diseñador actúa sobre la cultura trascendiendo los límites del propio producto, convirtiéndose en un 'operador cultural'. (...) Este diseñador es un profesional en el que se combinan el dominio del 'oficio' con el conocimiento y dominio de los códigos de la cultura, sobre todo de la cultura visual y la sensibilidad para anticiparse a su tiempo, sin estar fuera de él". (Ledesma, 2010)

En el DG, como en cualquier otro de los diseños, lo importante no son los objetos, sino las situaciones y los procesos. "El objetivo del diseñador de comunicación visual es, entonces, el diseño de situaciones comunicacionales". (Frascara, Diseño Gráfico para la gente, 1997)

El/la diseñador/a gráfico/a entonces, sería un/a profesional con la capacidad de resolver los problemas con claridad de forma y contenido, tener dominio en el manejo de los medios disponibles y considerar permanentemente los aspectos económicos, culturales, sociales, tecnológicos y ecológicos de cada proyecto. (Frascara, El diseño de comunicación, 2011)

¿Y entonces, cómo podría el profesional del DG llegar a cumplir de la mejor forma y tomando en cuenta todos estos aspectos?

Re-tomo a continuación la descripción de ciertas prácticas que con mucha claridad expone Raquel Pelta ${ }^{11}$ :

“Practicar un «diseño consciente» supone ser sensible al contexto y a las relaciones que implica:

11. Doctora por la Universidad de Barcelona, Licenciada en Geografía e Historia y Licenciada en Comunicación Audiovisual. Profesora de la Facultad de Bellas Artes de la Universidad de Barcelona, es historiadora del diseño y autora de numerosos artículos publicados en libros y revistas especializadas. Miembro del Patronato de la Fundación Historia del Diseño, en 2011 recibió el Premio Gràffica «por su aportación a la investigación en la historia del diseño gráfico español y su capacidad para impulsar proyectos en torno al diseño.» 
Pensar en las consecuencias de las acciones de diseño antes de ponerlas en marcha prestando especial atención a los sistemas naturales, industriales y culturales que se encuentran en el contexto donde dichas acciones tienen lugar.

Tomar en consideración qué material y energía están presentes en los sistemas que diseñamos.

Dar prioridad a la entidad humana y no tratar a la gente como un simple «factor» dentro de algo mayor.

Proporcionar valor a las personas y no personas al sistema (como en la mayoría de los casos hace el marketing actual).

Tratar el «contenido» como algo que hacemos, no como algo que vendemos.

Concebir el lugar, el tiempo y la diferencia cultural como valores positivos, no como obstáculos.

Centrarse en los servicios y no en las cosas y abstenerse de inundar el mundo con artefactos carentes de sentido".

(Pelta R., 2011)

Claramente lo anterior podría aplicarse con mayor efectividad cuando de trabajo independiente hablamos o cuando el/la diseñador/a gráfico/a tiene total poder de decisión sobre los proyectos en los cuales trabaja. Por ello es importantísimo también para mi trabajo en esta tesis, contribuir para hacer entender a los/ las diseñadores/as, sin importar en qué empresa o lugar realicen su trabajo, sea independiente, en una pyme, una multinacional o una ONG, sea su cargo directivo o junior, que hay acciones que por pequeñas que parezcan, se pueden ejecutar, ya que en cada proyecto a diseñar el/la profesional toma diversas decisiones, desde la ideología y los valores con los cuales comunica el mensaje, hasta el formato, el papel o la tinta que propone para desarrollar el mismo.

En este sentido, el artículo "Cómo iniciarse en el Diseño con Consciencia Social", publicado en Foro Alfa por la Red de Diseñadores con Consciencia Social, asociación civil argentina con nueve años de trayectoria, da luces sobre el tema: 
"Pero, iqué sucede cuando los clientes y proyectos laborales no permiten al diseñador incorporar nociones de consciencia social a su trabajo?

Se pueden generar proyectos profesionales o altruistas que complementen a los netamente comerciales, sondeando necesidades urgentes de la sociedad. Martín Churba es un diseñador que ha tenido experiencias en ese sentido.

Se pueden incorporar sugerencias sustentables en los lineamientos de trabajo, en el momento de la presentación del proyecto ante el cliente.

Se puede investigar y estudiar sobre un tema, contagiando a la comunidad de diseñadores, fomentando un estilo de vida y de profesión". (Red de Diseñadores con Consciencia Social, 2014)

En este punto para mi, resulta más que claro el papel determinante de la profesión del DG y a la vez me surgen muchas más inquietudes sobre ese rol, que afortunadamente no he sido la primera en tener:

“En esta línea de análisis me pregunto: ¿Por qué razones una práctica tan dependiente de los cambios sociales y económicos, aparece -paradójicamente- tan ajena a ellos? ¿Por qué motivos se sigue desconociendo la existencia de una dimensión política en las imágenes y el rol que ella juega en el DG? ¿Qué prefiguración del "público" construía el DG en sus inicios, y cual es la diferencia con los actuales usos y destinos de sus piezas? Preguntas y razones que explican no solo los sentidos dominantes que van modelizando el DG, sino el imaginario social que lo acompaña como práctica profesional". (Devalle, 2009)

Considero que el/la diseñador/a gráfico/a como ser humano, puede preocuparse por ir más lejos de lo que llega hoy en día, para lograr contribuir con su forma de trabajo de manera positiva a una transformación social que aunque pueda ser lenta, sea profunda, convirtiéndose en creador de contextos en donde todas sus vértices respondan a un mismo objetivo: Rediseñar mundos. 


\subsection{Con consciencia social y también económico}

"El mercado es producto de nuestra especie, no lo podemos poner del otro lado como si fuera un cuco y nosotros las pobres víctimas. Es, desgraciadamente, un producto humano; no brotó de ningún árbol. Lo que estamos tratando de resolver en reuniones como esta es lo que haremos con esta situación que no nos gusta y que es producto de toda una consecuencia de existir y de padecer. Como dice Yves (Zimmerman), si consumimos conocimiento, defecamos conocimiento".$^{12}$

Como lo dice Silvia Fernández, el mercado es producto del capitalismo creado y sostenido por el ser humano, quise mencionar este aspecto para plasmar mi reflexión al respecto ya que no son pocos quienes lo mencionan cuando se habla de Diseño con Consciencia Social.

Hay muchos diseñadores y diseñadoras gráficos/as que consideran que quienes tenemos objetivos menos comerciales y más humanos y a la vez somos parte del sistema y nos movemos dia a día dentro de él, vivimos en una especie de ilusión hipócrita por creer que con la actitud hacia nuestro trabajo podemos hacer algún aporte o cambio en el planeta. El punto de vista de Norberto Chaves, uno de los más reconocidos asesores y diseñadores en el campo del identidad corporativa mundial, es bastante claro y por demás honesto consigo mismo en este sentido. En la conferencia dada por él en el ciclo "La formación del diseñador y la práctica profesional", realizado con motivo del $10^{\circ}$ aniversario de la revista tipoGráfica, dice:

“Rechazo de plano toda concepción de la profesión como entelequia o como cruzada cultural o social. Considero a mi profesión, como un oficio entre otros, aleatorio y abandonable en cualquier momento $y$, por lo tanto, incapaz de despertar identificación gremial alguna. (...) Se comprenderá entonces que a partir de estas convicciones yo carezca de utopías

12. Fragmento de intervención hecha por Silvia Fernández en la mesa redonda final, el marco del ciclo "La formación del diseñador y la práctica profesional", realizado en Buenos Aires en 1997 por la revista tipoGráfica con motivo de su $10^{\circ}$ aniversario. Tomado de su edición $\mathrm{N}^{\circ} 33$, p.p. 42. 
profesionales. (...) Mi capacidad de utopía -que suele ser alta- la deposito en objetivos superiores que trascienden por completo al mero ejercicio profesional. Mi única utopía es social. Y, en todo caso, lo único que dicha utopía prevé respecto del diseño es su desaparición" ${ }^{13}$

Cuando leí ese comentario inmediatamente recordé que alguno de mis profesores en la Universidad Nacional de Colombia durante mi carrera me dijo: "No somos diseñadores de 8 a 6 , lo somos las 24 horas del día, si te interesa el diseño debe interesarte para vivirlo, no sólo para trabajar en él". Y es algo en lo que creo firmemente. Aunque respeto completamente el punto de vista de todos y todas los/as colegas que consideran que sin mercado comercial el diseño desaparecería, no creo en lo absoluto que mi profesión tenga razón de existir solamente con fines económicos, felizmente durante el proceso de investigación de esta tesis pude encontrar conceptos que apoyan mi pensamiento.

En el mismo ciclo los organizadores realizaron una mesa redonda a modo de cierre, de la cual quise rescatar una pregunta que considero clave con relación a esta tesis: “¿No le parece incoherente y quizá poco ético trabajar para un mercado competitivo que no tiene los valores que usted dice tener?"

Hubo respuestas diferentes que demostraron la variedad de pensamientos en la profesión y lo problematizante que resulta este tema para los y las diseñadores/as. De esas respuestas me interesa resaltar la de Jorge Frascara, uno de los diseñadores y autores que me inspiraron para decidirme por mi tema de tesis de maestría, y también la de Norberto Chaves, como pensamiento opuesto e igualmente respetable.

Norberto Chaves:

“(...) Y no me parece falta de ética, a menos que así se considere el hecho de trabajar para un sistema que tiene esas características, cosa que hacemos la amplísima mayoría de ciudadanos. Es difícil escaparse de condiciones de trabajo

13. Fragmento de la conferencia de Norberto Chaves en el marco del ciclo "La formación del diseñador y la práctica profesional", realizado en Buenos Aires en 1997 por la revista tipoGráfica con motivo de su $10^{\circ}$ aniversario. Tomado de la revista tipoGráfica $\mathrm{N}^{\circ} 33$. 
donde la totalidad de las prácticas: culturales, universitarias y académicas, y también las instituciones: museos, salas de exposiciones, organizaciones barriales y gremios, están regidas por el sistema de mercado. (...) Por otra parte, me parece que si la ética se mide por la relación contractual que establece el profesional con un cliente con quien contrae una serie de compromisos, entonces no veo ninguna contradicción en tener un amplísimo respeto por mis clientes y un absoluto desprecio por una sociedad que me parece abyecta. Muchos de mis clientes son víctimas de esa situación y les gustaría huir igual que a mi. (..) Lo que pasa es que algunos no tenemos esa opción, o no nos interesa o la realizamos paralelamente. Yo también escribo poemas y les puedo asegurar que son muy buenos". ${ }^{14}$

Jorge Frascara:

"Acabo de terminar un libro que se va a publicar en octubre y cuyo título es Diseño gráfico para la gente. En el proceso de definir su nombre, alguien me sugirió ponerle Diseño gráfico para el consumidor, pero no era para nada lo que yo pretendía. No somos consumidores, somos gente. Es cierto que estamos consumiendo todo demasiado y que la terminología se excede en su aplicación. Hace algunos días, en una reunión en mi universidad, un estudiante de un programa de doctorado en sociología se refirió al consumo del conocimiento. El conocimiento no se puede consumir, se adquiere, se olvida, se intercambia y se discute, pero no se consume" ${ }^{15}$

Para mi, ver como algunos/as creen que la labor del diseño es en esencia comercial y que sin este aspecto dejaría de ser tal, despertó aún más mi interés en descubrir maneras de refutar esa idea y llevarlas a cabo en mi realidad. Incluso si se cree que si las cosas o situaciones son como son por que así es la vida que nos tocó vivir, y entonces lo que nos queda es acomodarnos de la mejor forma en ella:

"Desde esta posición puede entenderse que, profesionalmente hablando $(\mathrm{O}$ sea con contrato, honorarios y recursos técnicos), no se puede hacer nada que carezca de

14. Fragmento de respuesta en mesa redonda referenciada en la edición $\mathrm{N}^{\circ} 33$ de la revista tipográfica, p. 42, año XI, Buenos Aires, Argentina.

15. Ídem. 
realidad. Clientes son los que pagan y las causas nobles carecen de presupuesto. Desde ya sería bueno que, me haría muy feliz que aparecieran otros encargos, muchas otras y mejores tareas, problemas más humanos que pudieran resolverse profesionalmente y en los que me encantaría trabajar. Pero esta sociedad no los aborda. Por algo será". ${ }^{16}$

Creo que estamos en el proceso de despertar esas actitudes y problematizar nuestros pensamientos, justamente para abordar cada vez más ese tipo de proyectos que en principio y para muchos/as son ideales y difcíles de realizar, esto sin querer decir que estos trabajos deban ser siempre ad honorem, es claro que nos movemos en un contexto capitalista, pero creo que esto no significa que debamos entonces participar activa y conscientemente de este sistema, porque de lo contrario seremos hipócritas o estaremos yendo en contra de nuestro pensamiento.

Justamente en el siguiente apartado menciono ejemplos de diversas prácticas que son prueba de que esto es posible y realizable.

\subsection{Mirada a las prácticas actuales}

Abordaré en este ítem algunos de los ejemplos con los cuales encontré en mi recorrido y que me ayudaron a entender desde diferentes puntos de vista, cómo los y las profesionales del DG están entendiendo y practicando la disciplina, ya sea centrando sus esfuerzos en causas sociales, en el proceso de diseño o en el público a quien llegar. Los elijo como muestra de práctica porque por diferentes motivos son personas que ya han empezado a hacer realidad esa idea de rediseñar mundos.

16. Fragmento de la conferencia dada por Norberto Chaves en el marco del ciclo "La formación del diseñador y la práctica profesional", realizado en Buenos Aires en 1997 por la revista TipoGráfica con motivo de su $10^{\circ}$ aniversario. Tomado de la revista tipoGráfica $N^{\circ} 33$, p. 33, año XI, Buenos Aires, Argentina. 


\subsubsection{Panorámica mundial}

\section{Design for good (Estados Unidos)}

Un siglo atrás, en 1914, se creó la organización sin ánimo de lucro norteamericana AIGA (American Institute of Graphic Arts), con la perspectiva de que los diseñadores desempeñan un papel importante como comunicadores, educadores e innovadores y cuya misión es promover el diseño como un oficio profesional, una herramienta estratégica y una fuerza cultural vital. Esta organización recientemente (2009) incluyó la red Design for good, un ejemplo actual que promulga esta idea de consciencia sobre el resultado y consecuencias del trabajo creativo, tal como explican en su sitio web:

Design for good (o Diseño para el Bien), es una plataforma para construir y sostener la puesta en práctica del pensamiento del diseño para el cambio social. Esta plataforma crea oportunidades para los diseñadores a construir su práctica, su red y su visibilidad. Reconoce la amplia gama de trabajo de los diseñadores y el liderazgo en el cambio social que beneficie a todo el mundo, nuestro país y nuestras comunidades. Apoya y sostiene a los diseñadores que juegan un papel catalizador en las comunidades a través de proyectos que generen impacto social positivo. Al conectar y potenciar a los diseñadores a través de herramientas de redes en línea, historias inspiradoras, capacitación, defensa nacional y promoción, Design for good sirve como un poderoso recurso para los diseñadores que desean trabajar en este área y un faro para los diseñadores que actúan como líderes en su entorno". (AIGA)

\section{The Yes Men (Estados Unidos)}

Esta organización surge desde dos de los fundadores de otro grupo activista denominado RTMark (http://www.rtmark.com/), el cual se dio a conocer en 1993 por intercambiar las voces de un lote de muñecas Barbie y muñecos $\mathrm{Gi}$ Joe como forma de protesta hacia el carácter sexista de estos juguetes. En su sitio web se definen:

"Así como las corporaciones son entera y únicamente máquinas de incrementar la opulencia de sus accionistas (a menudo en 
detrimento de la cultura y la vida), RTMark es una máquina de mejorar la cultura y la vida de sus accionistas (a menudo en detrimento de las opulencias)".

Andy Bichlbaum y Mike Bonanno crearon el colectivo The Yes Men practicando lo que ellos denominan "corrección de identidad", que consiste básicamente en hacerse pasar por dirigentes políticos, voceros económicos o empresarios influyentes y poderosos para desenmascarar a las corporaciones multinacionales que con su red de negocios afectan social, económica y ambientalmente de forma negativa a los ciudadanos y al planeta. A través de la sátira, han logrado cambiar momentáneamente los discursos de organizaciones como la OMC, McDonalds o Dow Chemical, logrando además que la prensa voltee su mirada a asuntos olvidados y naturalizados en el mundo. Existen películas documentales realizadas por ellos mismos donde muestran sus intervenciones y las reacciones que han conseguido con ellas (theyesmen.org).

Aunque no es un colectivo específicamente enfocado en diseño, sus intereses y objetivos son directamente sociales y culturales, por tanto se valen muchas veces de los medios gráficos para comunicar sus ideas y para apoyar los mensajes que quieren transmitir. Un ejemplo perfecto de ello es el proyecto, en el cual los Yes Men se unieron a escritores, artistas y activistas independientes, para desarrollar una especie de edición especial del New York Times, justo una semana después de las elecciones presidenciales de EE.UU donde el ganador fue Barack Obama.

El diario, que estaba diagramado exactamente igual al original y fue distribuido gratuitamente en las calles de New York, tenía fecha del 4 de julio de 2009, un año después de la posesión presidencial, porque la idea era mostrar las noticias que podrían hacerse realidad si los ciudadanos exigían al presidente elegido cumplir con las promesas hechas siendo candidato.

Incluía noticias como: "Termina la guerra en Irak", "Salud pública nacional para Estados Unidos" o "Petroleras nacionalizadas para usar fondos en favor del cambio climático". Los autores indican en su sitio web: "Queríamos experimentar cómo se vería y sentirían 
los ciudadanos al leer los titulares que realmente queremos leer. Se trata de lo que realmente es posible, si pensamos en grande y actuamos en conjunto". (The Yes Men y otros, 2008)

\section{Regráfica: http://regrafica.org/ (España)}

Es un sitio web que funciona como banco de imágenes de carteles de libre descarga para difundir las causas sociales. Convoca a diseñadores/as gráficos/as que deseen participar enviando un cartel sobre cualquier tema de su interés, haciendo contra-publicidad o carteles reivindicativos, que a su vez se publicarán para descarga gratuita en este mismo sitio web. Ellos se definen como:

“Diseñadores con consciencia social y estamos convencidos de que el diseño puede hacer algo para la sociedad y no contra ella, así que usamos los conocimientos de comunicación gráfica que poseemos para diseñar y compartir carteles que contengan reivindicaciones sociales y divulguen la realidad (social, económica, cultural, multinacional) en la que nos encontramos, o que causen efecto positivo en la sociedad. Nuestro objetivo es que estos carteles se compartan, se descarguen, impriman y pongan en los muros de la ciudad". (Regrafica)

\section{Y continúan reflexionando:}

"Lo que hacen los diseñadores gráficos y creativos es definir una estrategia de marca, y conforme a ella diseñar imágenes corporativas para las empresas/entidades, con su logo, su gama cromática, sus aplicaciones, la página web, el manual de estilo, y la publicidad en múltiples formatos.

Aunque muchos/as diseñadores/as trabajan para pequeñas y sostenibles empresas y algunos/as otros/as quizá tengan la suerte de diseñar para hospitales o centros de educación, también los/ as hay que diseñan para los Bancos, petroleras y otras malvadas corporaciones que quieren adueñarse del mundo. De una forma u otra, el DG y la publicidad estática o audiovisual contribuyen en mayor parte a la economía global.

Con la repercusión que la publicidad tiene en la sociedad, publicistas, creativos y diseñadores gráficos adquieren una 
responsabilidad enorme. Pero algunos siguen el guion marcado por las irresponsables corporaciones que siempre quieren más y más ganancias económicas a cualquier precio, intentando manipular a las masas para su beneficio. Pero no toda la publicidad es así, la hay con consciencia social, hay empresas que se preocupan para que su publicidad pueda beneficiar el comportamiento del usuario y hacer reflexionar.

Y hay diseñadores, creativos, ilustradores, publicistas, que no tienen por clientes a empresas, que hacen diseño gráfico y publicidad que no se vende, que se regala, que se comparte, con mensajes de advertencia, esperanza, o con algo que nos haga reflexionar, con buenas intenciones y sin ánimo de lucro". (Regrafica)

\section{Hoy es el día, estudio de diseño (España)}

Este es un estudio de DG especial en su clase, ya que su objetivo es prestar los servicios de diseño que generalmente prestaría cualquier estudio de este rubro, pero con un enfoque específicamente social, responsable y sostenible, además teniendo en cuenta la economía local, convirtiendo a sus proveedores y colaboradores en una red que se retroalimenta y sostiene el negocio. No se trata solamente de DG activista, sino de aplicar esta perspectiva en todo proyecto que emprendan independientemente del cliente que los haya contratado.

En una entrevista realizada para esta tesis indican:

“Hoy es el día nació con el objetivo de utilizar el diseño gráfico como vehículo generador de cambios positivos en la sociedad. Somos un estudio de branding y diseño gráfico responsable, comprometido y sostenible. El diseño gráfico tiene un gran potencial para aplicar metodologías sostenibles a nivel social, económico y medioambiental en proyectos de cualquier índole, ya que se pueden aplicar desde el estudio con nuestro sistema de toma de decisiones y código ético como en la definición de los proyecto de nuestros clientes.

Así, nuestras acciones pueden ir desde la elección de nuestros proveedores o recursos a la creación de planes de 
responsabilidad social corporativa o campañas sociales como parte de la definición de marca de nuestros clientes". ${ }^{17}$

Al consultar cómo logran abordar el trabajo desde esta perspectiva y también seguirse moviendo dentro de las lógicas del mercado capitalista, responden:

"Es complicado, y en ocasiones desalentador. Y se logra diciendo NO muchas veces a proyectos que no responden a nuestras exigencias. (Esto resulta en ocasiones muy difícil, porque efectivamente, todos nos movemos en un mercado capitalista donde las necesidades económicas no entienden de ética). Sin embargo, el tiempo me ha enseñado que no es necesario que tu cliente sea especialmente sostenible para que tu trabajo lo sea. Aunque por supuesto, un cliente de Hoy es el día nunca sería ANTI-sostenible.

Como comentaba antes, la propia toma de decisiones en nuestro día a día, como elegimos un formato, un papel, una tinta, un proveedor... aporta a la generación de cambios. Y por supuesto, en esta toma de decisiones también se incluyen proyectos y clientes que entiendan esta postura y no atenten contra nuestra filosofía.

El diseño gráfico puede servir como elemento dinamizador de esos cambios, pero no puede trabajar sólo. Tiene un gran poder para cambiar actitudes, concientizar y sobre todo crear puentes de comunicación que sirvan para esa transformación". ${ }^{18}$

Consideran fundamental mostrar a los/las estudiantes de DG perspectivas diferentes desde la carrera, porque se estaría ayudando a crear una nueva generación de profesionales para quienes la sostenibilidad y la conciencia social serán un elemento básico que abordarán con naturalidad. Ahora, es un elemento añadido que incluimos en nuestra perspectiva solo algunos/as diseñadores/as. Si se incluyera como elemento de estudio en las carreras, el proceso transformador sería mucho más veloz y efectivo.

17. Entrevista realizada a su fundadora Mari Carmen Estevan vía internet en julio de 2015.

18 Ídem. 


\section{Diseño Social En+ (España)}

Diseño Social En+ es una organización sin ánimo de lucro cuyo objetivo principal es ayudar a promover el diseño y la comunicación, más allá de la sola idea de protesta o activismo, para buscar soluciones a través del diseño. "Nuestras intervenciones buscan fomentar la comunicación positiva de interacciones que implican creación de proyectos basados en la creatividad, empatía y sinergia". (Diseño Social En+)

Se esfuerzan por integrar ONG's a diseñadores y diseñadoras interesados/as en la perspectiva social, para que estos les ayuden a mejorar su comunicación interna y/o externa. Quienes se encuentren interesados en colaborar, se ponen en contacto con Diseño Social En+ para ofrecer sus servicios, y a su vez este lo conecta con la organización correspondiente para llevar adelante el proyecto que requiera.

A través de la generación de su blog y de grupos de investigación y cursos de formación, presencial y/o a distancia a través de internet, en su mayoría gratuitos, Diseño Social En+ difunde y proyecta temas de real importancia dentro de la perspectiva del Diseño con Consciencia Social y la comunicación.

“Debemos ser conscientes del hecho de que tenemos la oportunidad de elegir las acciones en la vida cotidiana. Tenemos la opción entre seguir los mismos hábitos, las costumbres y los senderos que marcamos en el pasado, cambiarlos por otros o diseñar nuevos caminos. Para nosotros este es el diseño social, ¿cómo podemos, desde nuestra pequeña realidad, diseñar nuestro mundo? En la era de la información, la interconexión y las redes sociales, en el ámbito del diseño también necesitamos profesionales pero también de gente que lo aplique en todas las facetas de su vida: artesanos, ilustradores, diseñadores, arquitectos, ecologistas, escritores, campesinos, periodistas, amas de casa... También necesitamos una formación "social y cívica" mínima para que las ideas se encaucen y no queden en meros pensamientos pasajeros. Hay múltiples formas de hacerlo y nuevas metodologías para aplicar y revisar a cada paso. También la experiencia de personas creativas en su día a día. Pero lo más importante quizás, es no olvidar que todos, absolutamente todos, 
formamos parte activa del mundo que pisamos. Las posibilidades de rediseñar el mundo son infinitas pero tienen un paso previo indispensable: rediseñar nuestra forma de pensar". ${ }^{19}$

En relación a esa contraposición con el mercado tradicional que se genera entre éste y el Diseño con Consciencia social, mencionan:

“El concepto “diseño social" es un término vivo, en evolución. Nace en contraposición del concepto de diseño orientado a fines meramente comerciales. Pero no tienen por qué ser términos opuestos. (...) debe ser un término que construyamos desde su propia realidad, y no en contraposición al diseño orientado a fines comerciales. (...)

Ahora sabemos que hay otra forma de hacer las cosas y que, entre todos, podemos diseñar y rediseñar otra realidad. Las marcas comerciales ya lo han detectado. Han asimilado que no pueden luchar contra esa pulsión y se han sumado a ella disfrazándose de anuncios en los que ya no se vende estatus, sino valores. El siguiente paso es que se vean obligados a quitarse el disfraz de marketing y RSC y sean empresas verdes, sociales y sostenibles $100 \%$. Llegará, y espero que sea antes de que sigamos realizando daños irreversibles al planeta y a la vida de tantas y tantas personas". ${ }^{20}$

\section{The Doors of Perception (UK)}

Es un proyecto creado y dirigido por John Tackara ${ }^{21}$ cuyo objetivo principal es promover y educar sobre un sistema coherente que sume sostenibilidad, diseño, innovación y negocio. Propone una perspectiva de diseño con un nuevo entendimiento

19. Entrevista realizada vía internet a una de sus fundadoras, María Hidalgo, en julio de 2015.

20. Ídem.

21. John Tackara es un escritor, periodista, investigador y diseñador experto en diseño e innovación, de origen inglés. Autor de diversas publicaciones cuyo tema central es el diseño con conciencia social, el más reconocido y reciente In The Bubble: Designing In A Complex World" (En la burbuja: Diseñando para un mundo complejo). Durante muchos años fue director de investigación en el Royal College of Arts de Londres y del Instituto Holandés del Diseño, además dirige "The Design Observer" y la sección sobre diseño de "The Spectator". 
de los objetivos de la profesión. "Producimos tecnología con alto nivel de significado pero con falta de propósitos, perdemos la claridad respecto a cuáles son los valores que le aporta a la vida de las personas". (John Tackara). Propone un diseño consciente, responsable y ético que utiliza la innovación y el desarrollo en pro de la humanidad frenando la proliferación de objetos sin un horizonte concreto o coherente, y ubicando a las personas en primer lugar antes que el crecimiento económico.

A través de este proyecto, Tackara hace las conversaciones en vivo y en línea, produce eventos para ciudades, instituciones y organizaciones de todo el mundo. Los resultados de cada colaboración son, por lo general una percepción compartida de nuevas oportunidades; una buena idea de cómo explotarlos y nuevas conexiones entre las personas que hacen esas acciones ocurran. (John Tackara)

Además de lo mencionado anteriormente, no está de más nombrar la importancia de la actividad de decenas de blogs y sitios web nacidos de las inquietudes y reflexiones de diseñadores y diseñadoras, que desde diferentes zonas del planeta y casi simultáneamente, han sentido la necesidad de alzar su voz sobre el papel del diseño en general y el gráfico en particular. Aquí algunos ejemplos:

Voces con futura (vocesconfutura.org)

Designthinks (designthinks.blogspot.com)

Contra-cola (www.contracola.org)

Grafous (www.grafous.com)

Social Design Zine (socialdesignzine.aiap.it)

Consume hasta morir (www.letra.org)

Design-altruism-project (design-altruism-project.org)

Socialdesignsite (www.masartemasaccion.org)

Design cares (www.designcares.com)

Social design notes (backspace.com/notes)

Design can change (www.designcanchange.org)

Un mundo feliz (unmundofeliz2.blogspot.com) 


\subsubsection{En América Latina, ¿Cómo se está trabajando?}

\section{Desde la sociedad civil}

En Latinoamérica, más específicamente en Chile, el cartel ha sido un medio muy utilizado por su efectividad, sencillez de producción y alcance visual. Hay antecedentes desde inicios del siglo XX, con diferentes manifestaciones gráficas activistas, apoyando causas estudiantiles. Recientemente en 2011 se armó todo un movimiento, acompañando las luchas juveniles por la educación gratuita, consigna principal de estas protestas, dado el modelo educativo apegado al neoliberalismo que aún permanece en ese país.

Un aspecto interesante de esas manifestaciones iniciadas por los/ las estudiantes es la estética con la cual se manejaron las expresiones de protesta. A diferencia de años anteriores, apareció un gran despliegue visual, con disfraces, danzas, pancartas, esculturas, pinturas que conformaban una perspectiva casi teatral, lo cual llamó la atención y contagió al resto del país como en un carnaval, sumándose cada vez más grupos a estas manifestaciones.

Aunque las redes sociales fueron herramientas indispensables en estos movimientos, el cartel surgió nuevamente como una expresión valiosa de protesta en este contexto, usando pocos recursos y manteniendo un modo de producción rústico y artesanal, muy ligado al sentido de las protestas. Un nodo de estas expresiones fue la Facultad de Arquitectura y Urbanismo de la Universidad de Chile (FAU), en donde surgieron diversos grupos de estudiantes que usaron la creatividad como el mejor instrumento de expresión y protesta. (Vico, 2012)

En Argentina surgió una red con la intención de agrupar a publicistas de todo el mundo con interés en dedicar sus talentos a campañas con fines sociales y en favor del bien público: Publicitarios Sin Fronteras (http://www.awbnetwork.org). Se trata de un programa lanzado en 2004 por la fundación Ad Honorem, la cual se creó 10 años antes, como un portal web fundado por el publicista argentino Guillermo Caro. Se creó bajo la línea de otras agrupaciones "sin fronteras", como Médicos sin Fronteras. 
Se lanzó en ese año mundialmente con un anuncio que dice "Usted no necesita ser un superhéroe para unirse a Publicitarios sin Fronteras". Actualmente sigue vigente y cada vez agrupa más profesionales alrededor de todo el mundo.

También en Argentina, nació la Red de Diseñadores con Consciencia Social RED DCS, esta vez en un ámbito académico, específicamente en la Universidad de Buenos Aires. Es una organización sin fines de lucro cuyo principal objetivo es:

“Procurar aplicar todas las aptitudes creativas, proyectuales y de comunicación del Diseño en sus distintas ramas (Gráfico, Industrial, de Interiores, Textil, Audiovisual, etcétera) y afines en pos de temáticas de Bien Público. Desde entonces, ha desarrollado proyectos de todo tipo, en diversas locaciones y con diferentes destinatarios. No deja de capacitar a su comunidad local y a sus miembros constantemente en torno a la Comunicación y al Diseño. Impulsa permanentemente la Cultura con eventos de diversa índole como muestras, concursos, ferias, campañas fotográficas, entre otras. Pero su preocupación mayor es: lograr desde su área el fomento de valores que nos benefician a todos. (...) Los objetivos orientados a la urgencia social y el Diseño Sustentable. Por Diseño Sustentable entendemos productos y proyectos de DG, Industrial u otro que logran un equilibrio entre la Economía, el impacto Social y el impacto Ambiental o Ecológico". (Red de Diseñadores con Consciencia Social)

La organización sin fines de lucro Creatividad Ética (www. creatividadetica.org) nació en el año 2007 en Argentina como una asociación civil dedicada a la difusión de la creatividad en el diseño.

Esta organización ha venido generando espacios de reflexión, formación y construcción con eje en las políticas públicas, las buenas prácticas profesionales y productivas, la propiedad intelectual, los modelos de negocios, la sustentabilidad y la dimensión social de la creatividad y sus áreas de incidencia. Concentran sus esfuerzos en el desarrollo de diversas actividades de análisis, difusión y materialización de temas que consideran aún no han sido abarcados en su debida dimensión. A través de foros, conferencias, encuentros, concursos y la publicación de una revista digital bimestral, Creatividad Ética busca generar espacios de reflexión, discusión y participación 
en toda Latinomérica, concientizando sobre la importancia del diseño como herramienta estratégica en para la sociedad, desde sus dimensiones política, educativa e industrial.

Además Creatividad Ética brinda asesoría y capacitación a estudiantes, profesionales, empresas, instituciones educativas y gubernamentales en propiedad intelectual, comunicación, emprendedurismo, arquitectura sustentable, planes de negocios, estrategias y gestión de diseño entre otros. Como lo expresan en su sitio web: "Creemos en el diseño como herramienta para el desarrollo social, económico y cultural". (Creatividad Ética)

\section{Desde la empresa privada}

Así como grupos de ciudadanos se han unido movidos por sus convicciones a cerca de las capacidades del DG para la transformación, creando organizaciones sin ánimo de lucro y movimientos sociales que difunden estos pensamientos, existen empresas que aunque siguen constituidas como tal y su objetivo comercial sigue vigente, tienen como meta principal trabajar bajo la perspectiva del diseño con consciencia social. Esto es, evaluar muy bien los proyectos a desarrollar, tener en cuenta los mensajes que se transmitirán y participar de ellos, elegir los medios y/o materiales que se utilizarán sin olvidar las consecuencias ambientales y sociales, y además cobrar por ello como lo haría cualquier estudio de diseño.

\section{El Fantasma de Heredia (Argentina)}

Al llegar al final del libro de María Ledesma "El diseño gráfico, una voz pública", apareció un diálogo que la autora sostuvo con diseñadores de El fantasma de Heredia, un estudio argentino de diseño gráfico dedicado exclusivamente a temas culturales, sociales y políticos y fundado por diseñadores gráficos de la UBA. Allí relatan cómo una frase de un catálogo de Grapus ${ }^{22}$ los inspiró a continuar: "Nunca trabajé en algo en lo que no creyera".

22. Ver página 40 . 
Es un estudio de diseño gráfico que con total consciencia elige los proyectos con los cuales trabajar y que siempre va en línea con la ideología de sus clientes. Cuando la autora les pregunta si tendrían alguna propuesta respecto a la enseñanza del diseño gráfico, dicen:

“El diseño no se enseña aisladamente desde una cátedra de DG, cada materia necesita del apoyo de las otras y si no hay una línea entre lo que los alumnos estudian, la cosa se pone muy difícil. (...) Hay unos cuantos problemas en nuestra carrera, pero quizás el más importante es no ofrecerles a los chicos, a lo largo de cuatro años, el espacio para debatir y practicar cómo llegar a ser, a la par de diseñadores gráficos, personas responsables del mundo que habitan". (Ledesma, 2010)

\section{Implicate.org (Argentina + España + México)}

Esta es una agencia de comunicación que trabaja únicamente para organizaciones y proyectos que tengan un fin social. En su sitio web explican "Ponemos nuestro talento para apoyar causas que compartimos y tenemos una lista negra de corporaciones para las que no trabajaremos. Por eso, cuando hacemos comunicación hacemos activismo". Su objetivo es comunicar para provocar cambios. (Implicate, 2015)

En entrevista realizada para esta tesis, cuentan su posición con relación a aquella frase famosa que dice que "el cliente siempre tiene la razón":

"Es importante estar conectados con el caso a resolver, con la necesidad del usuario, del cliente. Esto no quiere decir que es el usuario que va a imponer su criterio ni que el cliente tiene razón, esto quiere decir que el DG conecta. Y no se puede conectar si no entendés lo que querés conectar. $Y$ para entender debes estar cerca. Cerca, entender al otro, entender la organización, entender el contexto de consumo del producto o servicio.

Esta frase plantea una relación de SERVICIO. Nosotros planteamos una relación de ALIANZA. El cliente NO tiene 
razón pero el cliente SABE lo que necesita. Hay que saber distinguir la necesidad e interpretarla" ${ }^{23}$

\section{Estudio San Francisco (Colombia)}

En su sitio web se presentan como un estudio creativo que trabaja para despertar consciencias. Llevan 14 años trabajando permanentemente con esta perspectiva y,

"Desarrollando estrategias de comunicación alineadas al desarrollo sostenible, cultura ciudadana y movilización social. La creación colectiva es nuestro eje metodológico pues creemos que las mejores ideas vienen de afuera. Solo hay que saber escuchar entendiendo el contexto de la comunidad. A través de talleres hablamos con nuestras audiencias y con ellas encontramos las soluciones para generar estrategias asertivas". (San Francisco Estudio Creativo)

Este estudio encontró la manera de moverse en el mercado tradicional y a la vez ser fiel a su posición frente a la responsabilidad de la profesión de los/as diseñadores/as.

\section{Desde las políticas públicas}

En años recientes en América Latina se comenzó a evaluar la necesidad de crear un espacio de reflexión sobre la urgencia de pensar y activar el diseño dentro de las políticas públicas de los estados, es así como en 2010 surgió la Red Latinoamericana de Políticas Publicas y Diseño, la cual está integrada por varios países de la región, realizando su primer congreso ese año en Buenos Aires, Argentina; el segundo en Bogotá, Colombia en 2011; el tercero en Octubre del 2012 en Guadalajara, México; el $4^{\circ}$ encuentro en octubre de 2013 en Uruguay y el $5^{\circ}$ y más reciente en 2014 en la ciudad de Guayaquil, Ecuador.

En su enfoque conceptual, expresa:

23 Entrevista realizada en junio de 2015 vía internet a Don Powa, uno de sus fundadores. 
"El diseño puede ser entendido tanto como recurso social, como entidad que se puede comprometer con el logro de propósitos de beneficio social. Así el diseño adquiere una dimensión política $y$, en cuanto sus aportes se presentan en campos diversos, se puede articular con diferentes áreas de gobierno o fortalecerse desde una política específica de diseño, orientada al cumplimiento de sus postulados sociales y su posterior adopción como política de estado". (Encuentro de Políticas Públicas y Diseños , 2010)

Según el documento de resultados del $2^{\circ}$ Encuentro, el objetivo general de la red consistía en:

"Crear un espacio de alto nivel, amplio e incluyente, para el análisis sobre el tema de políticas públicas, sus aproximaciones, enfoques conceptuales y especificidades para América Latina. Construir un marco de análisis sobre políticas públicas y sus relaciones con el diseño que siente las bases para la proyección y apertura de espacios para el diseño en ámbitos decisión política como elemento fundamental para su posicionamiento como estrategia de desarrollo de los países de la región". (Encuentro de Políticas Públicas y Diseños, 2010)

Aunque el modelo se tome de algunos de los países "primermundistas", y el efecto que este tipo de políticas ha tenido en ellos, tal como menciona Julio Frías:

“Ejemplos exitosos de Políticas Publicas de Diseño pueden encontrarse en Europa, Asia y Norteamérica. Basta decir que el caso de Corea del Sur ha sido uno de los más notorios, ya que este pequeño país se encontraba entre los más pobres del mundo hace 50 años y ahora es uno de los más prósperos, habiendo desarrollado marcas y productos que compiten «codo a codo» con las legendarias marcas japonesas. Finlandia es otro caso sui géneris, ya que este escandinavo país a pesar de haber sufrido invasiones de Rusia y Suecia es, de acuerdo a los reportes de competitividad, el país más competitivo y tiene los niveles de vida más altos del mundo. En el continente Americano Canadá es el más adelantado en este rubro" (Frías, 2012)

Resulta más que interesante encontrar cómo se ha empezado a pensar en nuestro territorio el rol del DG en un nivel de relevancia 
tal, donde se desarrollan ideas e iniciativas en conjunto, pensando y actuando como región.

Las actividades que desarrolla la red son diversas, ya que efectúa talleres entre sus miembros, realiza charlas, conferencias, mesas de trabajo y exposiciones. Se han tratado temas como la creatividad, la ética, industrias creativas, incubación de empresas creativas y de diseño, así como índices de diseño e iniciativas de gobierno.

Según la red, los resultados que se pretendía obtener al finalizar el $2^{\circ}$ encuentro, consistían en:

“Tener una batería de indicadores que se usarán de la siguiente forma:

- Documentos de consulta pública que demuestren el uso de indicadores en casos de éxito (o fracaso) a nivel sectorial, regional, nacional o continental. Estos documentos serán de utilidad en el momento de demostrar la importancia estratégica del diseño, para la organización.

- Documentos conceptuales para la adaptación de indicadores en cada región. Incluyendo un glosario de temas relacionados, modelos de análisis e implementación; y modelos de interpretación.

- Propuestas de normativas, leyes y políticas para estimular el diseño, en función de los indicadores anteriormente construidos.

- Propuesta de estímulos financieros y no financieros (compra pública, sellos y certificaciones /marca de autor, reconocimientos).

- Mapa de la región en tiempo real que demuestra un índice de desarrollo de diseño que se incluya en el índice de desarrollo humano, como el derecho al diseño". (Encuentro de Políticas Públicas y Diseños, 2010)

En el $\vee$ Encuentro, el cual fue organizado por el Ministerio de Cultura y Patrimonio del Ecuador, se "hace referencia a la transversalidad de la disciplina, que tiene por objetivo insertar 
el diseño como un sector estratégico dentro la sociedad del conocimiento y la economía de la cultura" (Encuentros Políticas y Diseños, 2014)

Sabiendo que el diseño no busca ser una solución prodigiosa, la idea de esta red y objetivo de sus encuentros, es fortalecer y apoyar la construcción de políticas que contribuyan al crecimiento de los países que la integran contribuyendo de manera muy positiva a la integración de la región.

Varios países del continente están implementando políticas de diseño entendiendo que es una manera de impulsar la industria, valorar el trabajo, crear identidad y bienestar. Considerándolo una herramienta estratégica que propicia la competitividad y el mejoramiento de la calidad de vida de la población, sin perder de vista que el buen diseño posibilita la diferenciación de los productos, mejora la producción, reduce costos, crea una identidad e imagen favorable y cuida y preserva el medio ambiente.

Citando nuevamente a Julio Frías:

"Si bien Argentina, Brasil, Colombia, Chile, Ecuador, Guatemala, México y Uruguay tienen retos diferentes en cuanto a su desarrollo, lo que tienen en común es su rica cultura y capacidad creativa, las cuales son potencializadas a través del diseño. Ejemplo de esto puede verse en la constitución del Centro Metropolitano del Diseño en Buenos Aires, la dinámica de la industria aeronáutica en Brasil con Embraer, o el Parque Tecnológico del TEC de Monterrey en México, por citar sólo unos ejemplos. Los diversos eventos de diseño, así como las publicaciones y evidencias en redes sociales, permiten afirmar que de una forma sostenible el diseño puede ser un factor de desarrollo para esos países Latinoamericanos". (Frías, 2012)

En Brasil, se lanzó en 2003 el Programa Brasileño de Diseño, el cual:

“(...) tiene como objetivo fomentar el reconocimiento internacional del diseño y de los productos y servicios desarrollados en Brasil así como el fortalecimiento de la marca Brasil. 
Este programa permite, a través de apoyo logístico y financiero, la participación de los productos brasileños en concursos y premios internacionales, logrando progresivamente visibilidad y reconocimiento internacional de la marca Brasil como factor de diferenciación de mercado. El diseño pasó a formar parte de la política industrial, tecnológica y de comercio exterior a partir de 1995 en el marco de la reestructuración y expansión competitiva del sistema industrial y de la puesta en marcha del Programa Brasilero do Design". (UNESCO, 2010)

En México, en abril de 2009 se estableció el dictamen final en la cámara de Senadores, sobre la importancia de los aspectos de la reforma sobre la inclusión en la legislación en materia de innovación, el cual sienta las bases para que el diseño sea el eje fundamental del desarrollo económico y el impulso industrial colaborando con la ciencia y la tecnología. Lo anterior significó que el diseño fue institucionalmente reconocido por el gobierno mexicano, y aceptado como agente fundamental para el desarrollo económico, tecnológico y productivo de la sociedad. (Frías, Foro Alfa)

Argentina también entró en etapa de concientización sobre la importancia de considerar el diseño como eje fundamental para la sociedad, por lo que se ha incluido en diversos espacios de reflexión que están resultando en la creación de proyectos desde el Gobierno.

En Argentina existe el Plan Nacional de Diseño (PND) como política pública, que se constituye en otro ejemplo a seguir en nuestro continente. Depende del Ministerio de Industria y fue creado por Resolución № 133/03 el 7 de mayo de 2003. Tiene como objetivo destacar al diseño como nuevo factor clave de la competitividad industrial, sensibilizar a los empresarios respecto a las ventajas de la incorporación de la gestión del diseño en la política de calidad de las empresas. Este proyecto procura aproximar las temáticas de diseño a la sociedad civil, tanto al consumidor como a las empresas, difundiendo los productos argentinos resaltando el valor de su diseño tanto en el país como en el exterior. 
En su misión destaca:

“Promover la incorporación de diseño en el tejido productivo a partir de estimular la vinculación entre diseñadores y empresas articulando con organizaciones intermedias". (Ministerio de Industria, Presidencia de la Nación) En su visión indica "consolidar una organización basada en la praxis (reflexión y acción) con representaciones en todas las provincias argentinas centrada en estrategias de diseño que aporten a la promoción del desarrollo industrial". (Ministerio de Industria, Presidencia de la Nación)

Una de las acciones concretas del PND es el Sello Buen Diseño, el cual es una distinción que recopila las labores de diseño a nivel nacional. En abril de 2012 se aprobaron sus bases y condiciones. En su sitio web se señala que:

"Los objetivos del programa son: Estimular el Buen Diseño de los productos fabricados por la Industria Nacional; promover los resultados exitosos de diseño de las empresas; incentivar el desarrollo de la producción nacional premiando las políticas estratégicas de mejora continua, la creatividad, la decisión, el cambio, el valor agregado y el talento y comunicar al consumidor y al usuario la importancia de la incorporación de diseño en los productos". (Prensa Argentina, 2012)

Desde entonces, año tras año, el Sello Buen Diseño ofrece a sus seleccionados diferentes opciones de capacitación, visibilidad en ferias sectoriales, oportunidades comerciales, y acciones de fomento para empresas, entre otras. (Ministerio de Industria, Presidencia de la Nación, 2015)

En síntesis, el PND gestiona el desarrollo regional, sectorial y la promoción del diseño, mediante estrategias para grupos de empresas y conglomerados productivos, además:

"Busca generar desarrollos genuinos que sean sustentables en el tiempo a fin de mejorar el estándar de vida de los productores locales a través de la valoración de la materia prima que poseen en sus localidades y de sus modos particulares de producción". (Plan Nacional de Diseño, 2012) 


\section{Desde la universidad pública latinoamericana}

A través de una lectura de las carreras que tomo como casos de estudio, indagando el tema desde sus respectivos planes curriculares, hice una mirada relativamente rápida de la evolución de estas carreras desde sus inicios, para detenerme en el plan vigente en 2015, teniendo en cuenta el contexto socio-económico de la carrera de diseño, de la universidad y del país, para descubrir allí la presencia del Diseño Gráfico con Consciencia Social y cómo los actores involucrados conviven y participan de ello. 


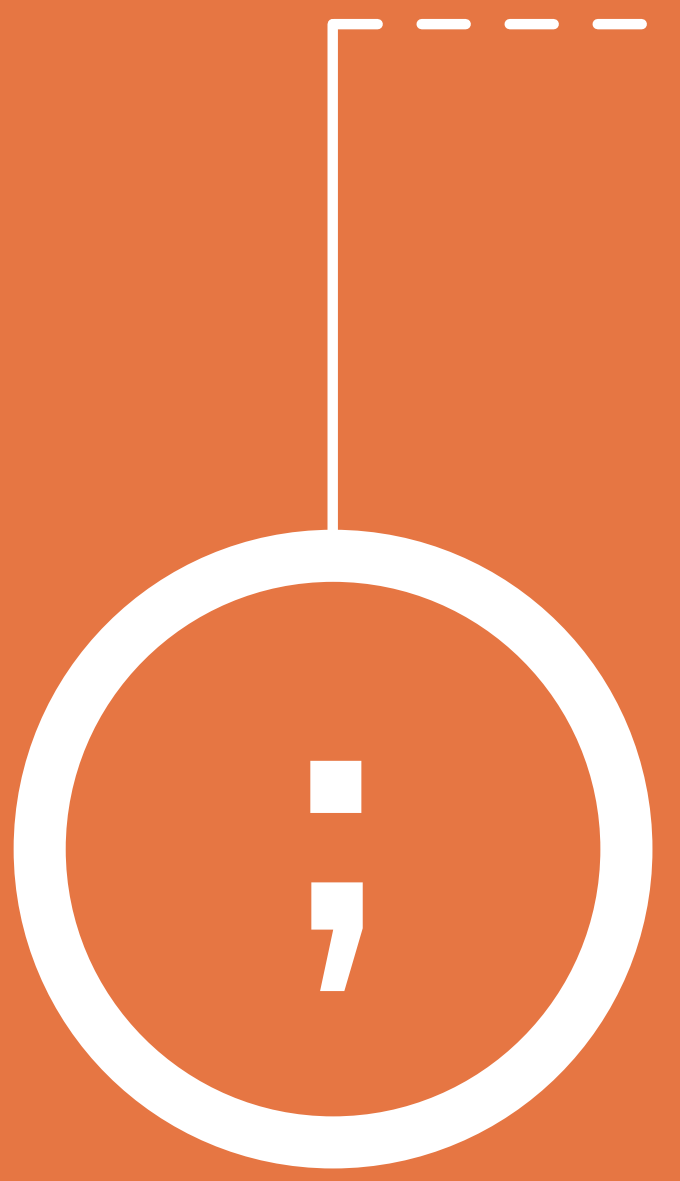




\section{PRESENCIA DEL DGGS EN LAS CARRERAS: CASOS ELEGIDOS Universidad de Buenos Aires Universidad Nacional de Colombia}

\subsection{Puntos clave en su historia ${ }^{24}$}

La carrera de Diseño Gráfico de la Universidad Nacional de Colombia (UN), pertenece a la Escuela de Diseño Gráfico de la Facultad de Artes, debido principalmente a que tiene antecedentes en las artes aplicadas (dibujo, grabado, litografía, imprenta), creándose como carrera profesional en 1963, enmarcado en la Escuela de Bellas Artes.

En la Universidad de Buenos Aires (UBA) la historia es diferente, ya que tiene sus primeros antecedentes en la creación de la Facultad de Arquitectura, Diseño y Urbanismo, en el año 1948. Un año que sería un punto clave no solo en la historia de la carrera, sino en diversos acontecimientos culturales a nivel mundial. En ese tiempo, el campo de la Arquitectura se encontraba en un período de debate de dónde estaba la línea que separaba al arquitecto del artista, y/o al arquitecto del ingeniero. La creación de la Facultad de Arquitectura vino a resolver de alguna manera esa situación, independizando la profesión, convirtiéndola en una disciplina autónoma.

Con todas estas experiencias previas y con una formación clara en esta facultad, fueron arquitectos quienes formaron la comisión de creación de la carrera de Diseño Gráfico en la UBA en 1984.

24. Ver infografías \#2 y \#3. 
Esta situación caracteriza el perfil de la carrera, la cual aún hoy en día continúa vinculada a la facultad de Arquitectura de la universidad.

Dos años después de la creación de la carrera en la Universidad Nacional de Colombia (UN) iniciaron los cambios que tendría el programa curricular, empezando por el nombre mismo de la carrera: Arte Gráfico Publicitario (evidenciando una intención inicial de configurar un programa comercial y publicitario, dado que era un área mucho más clara, práctica y reconocible en el entorno, mientras que el diseño gráfico era aún un concepto impreciso y desconocido en el país), tiempo después pasó a ser Licenciado en Arte - Diseño Gráfico Publicitario, permitiendo al término diseño nuevamente aparecer en escena. A lo largo de los años se fue alejando poco a poco del término publicidad, obedeciendo al "academicismo" presente en la UN como la forma de enseñar Bellas Artes y por extensión, Diseño Gráfico.

A mediados de la década del 70 se comenzaron a dar diversas discusiones entre publicistas y aquellos que se sentían más "diseñadores", donde participaban activamente estudiantes y profesores, y que finalmente terminaron eliminando esa dimensión publicitaria tan arraigada en el programa de estudios de la carrera en la UN.

Durante esta década hubo una nueva modificación en el plan de estudios, donde apareció una secuencia de asignaturas en comunicación visual en el plan curricular, impartidas por semiólogos y comunicadores, lo cual determinó claramente la esencia del programa de estudios como una disciplina con un soporte más teórico que práctico. En ese contexto, Armando Silva ${ }^{25}$ propuso una reorientación en la carrera planteando la creación de

25. Comunicador y semiólogo colombiano (1948- ), PH. D en Filosofía y Literatura Comparada de la Universidad de California. Autor de 16 de libros, entre otros: Imaginarios urbanos (con 10 ediciones y traducido en varias lenguas); Family Photo Album, ganador del premio a mejor tesis doctoral en las universidades de California (UMI, California, 1996); Urban Imaginaires from Latin America. investigador y Profesor Emérito de la Universidad Nacional de Colombia y profesor e investigador de la Facultad de Ciencias Humanas de la Universidad Externado de Colombia donde dirige el proyecto de doctorado en Estudios Sociales y Urbanos. (Tomado de https://armandosilva.wordpress.com/quien-es-armando-silva/) 


\section{MOMENTOS DESTACADOS}

\section{UNIVERSIDAD DE BUENOS AIRES}
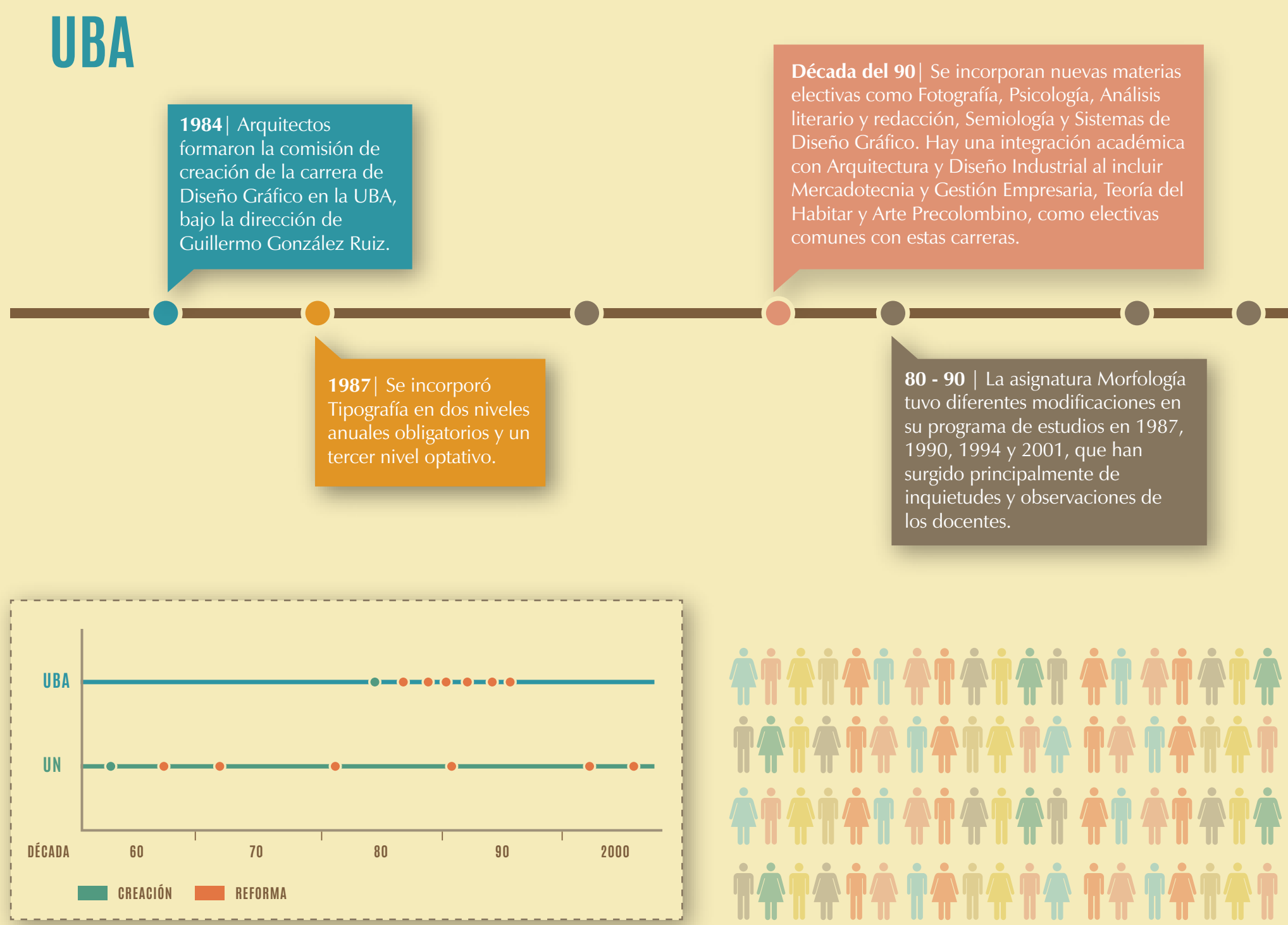


\section{MOMENTOS DESTACADOS}

HISTORIA DE LAS

CARRERAS DE DISEÑO GRÁFICO

\section{UNIVERSIDAD NACIONAL DE COLOMBIA}
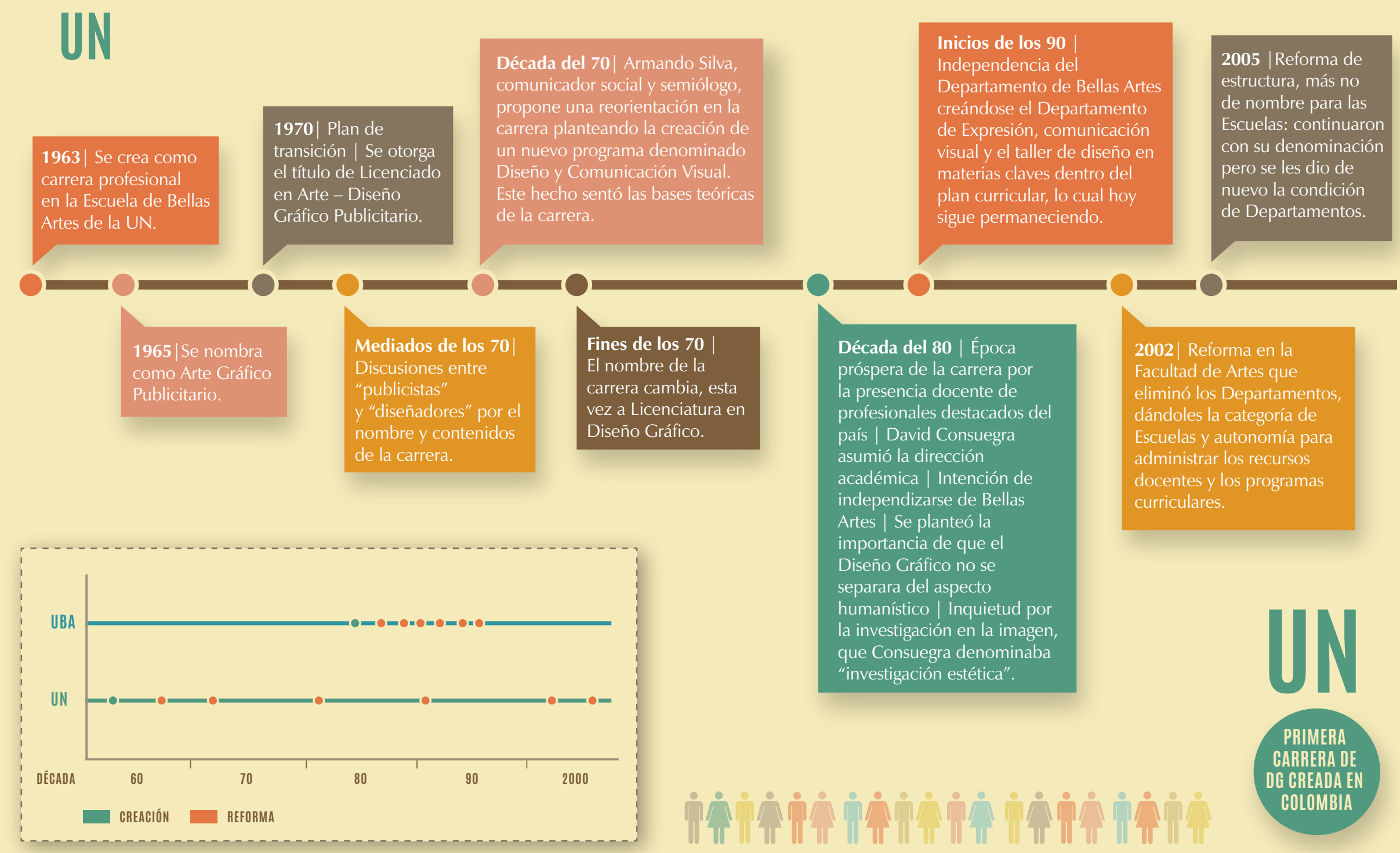
un nuevo programa denominado Diseño y Comunicación Visual, argumentando básicamente que el y la profesional en Diseño debía ser un sujeto crítico de su realidad y como tal enterado de la misma, capaz de intervenir en ella y en sus procesos sociales. Aunque esta propuesta no se llevó a cabo tal como se planteó, sí sentó las bases teóricas de la carrera.

En la década de los 80 , la carrera contaba con la presencia docente de los profesionales más destacados del país, entre ellos David Consuegra ${ }^{26}$, quien por esos años además asumió la dirección académica de la misma. Él mismo propuso un par de años después algunas nuevas reformas al programa curricular de Diseño Gráfico, con la intención de independizarse de Bellas Artes, ya que consideraba que no pertenecía a la misma línea ni tenía los mismos objetivos que la escultura, la pintura o el grabado. Además planteó la importancia de que el Diseño Gráfico no se separara del aspecto humanístico, y le interesaba sembrar en los estudiantes la inquietud por la investigación en la imagen, que él denominaba "investigación estética".

Era por esos mismos años que se estaba creando la carrera de DG en la UBA por una comisión de arquitectos, bajo la dirección de Guillermo González Ruiz ${ }^{27}$ el 23 de octubre del año 1984.

\footnotetext{
26. Diseñador gráfico colombiano (1939-2004), considerado uno de los pioneros de la profesión en el país, estudió Bellas Artes en la Universidad de Boston, se graduó con un Magna Cum Laude en 1961, inició estudios de maestría en diseño en la Universidad de Yale. Realizó un extenso trabajo de marcas, trabajo por el cual ganó mucho reconocimiento, también fue editor, dibujante, ilustrador, tipógrafo, fotógrafo y calígrafo. Es considerado un maestro del diseño gráfico en Colombia. (Tomado de http://redgrafica.com/DavidConsuegra-disenador-grafico)
}

27. Arquitecto y diseñador gráfico argentino (1937- ), fue diseñador gráfico de diversas agencias de publicidad. En 1968 integra el estudio González Ruiz / Méndez Mosquera / Ronald Shakespear, siendo socio de este último hasta 1973. Durante los años 1971 y 1972 fue director del grupo de diseño encargado de proyectar el Sistema de Señalización de Buenos Aires, hoy implantado en la mayoría de las ciudades del país. Entre los años 1985 y 1990 fue director de la Carrera de Diseño Gráfico de la Facultad de Arquitectura, Diseño y Urbanismo de la Universidad de Buenos Aires. Ha escrito diversos trabajos dentro del campo del Diseño Gráfico y sus obras han sido publicadas en revistas y anuarios de diseño de Inglaterra, Estados Unidos, Alemania, Suiza, Italia y Japón. Hasta 2011, fue profesor titular de las materias Diseño Gráfico 1, 2 y 3 de la carrera de Diseño Gráfico de la FADU. 
Es importante mencionar que no fue esta la primera carrera de Diseño Gráfico creada en Argentina. Ya en el año 1958 se había instituido en la Universidad Nacional de Cuyo el Departamento de Diseño y Decoración de la Escuela de Artes Plásticas, el cual después de algunos años y diferentes transiciones, Diseño pasa a formar parte de la Facultad de Artes, creada en 1980. A su vez, en 1963 se iniciaron las carreras de Diseño Gráfico y Diseño Industrial en la Facultad de Bellas Artes de la Universidad Nacional de La Plata.

Al contrario de lo que sucedió en la UNAL, en la UBA no hubo mayores cambios estructurales desde su creación, desde sus inicios y hasta el día de hoy pertenece a la Facultad de Arquitectura y Urbanismo (FADU) y siempre se llamó Diseño Gráfico.

En la UN, a inicios de los años 90, finalmente se logró la independencia del Departamento de Bellas Artes creándose el Departamento de Expresión y, paralelamente, disminuyeron las asignaturas ligadas directamente a las artes plásticas, convirtiéndose la comunicación visual y el taller de diseño en materias claves dentro del plan curricular, lo cual hoy sigue permaneciendo.

Por su lado, en la UBA, en sus inicios se dictó una sola cátedra a cargo del arquitecto Guillermo González Ruiz, quien contaba con la colaboración de diferentes docentes que participaron como profesores adjuntos, hasta que poco después obtuvieron la titularidad de sus propias cátedras. Es así como la carrera se organizó (de cierta forma extraoficial, ya que fue más por cuestiones prácticas, que por un dictamen de la misma universidad) en cinco diferentes áreas. Son áreas que han servido como guía en el momento de realizar reuniones con diferentes objetivos docentes y organizacionales y que se han mantenido a lo largo de los años: 1) Diseño (cátedras); 2) Morfología (cátedras); 3) Tipografía (cátedras); 4) Materias cuatrimestrales y optativas teóricas: historia, comunicación y optativas; 5) Materias cuatrimestrales y optativas prácticas: medios expresivos, tecnología y optativas. Esta estructura del plan de estudios se ha mantenido prácticamente igual desde su creación. (Mazzeo, 2014) 
En la UN por el contrario, hubo diferentes reformas estructurales y del plan de estudios, agregando y/o modificando algunas asignaturas en el plan curricular de la carrera.

\subsection{Planes curriculares vigentes en $2015^{28}$}

En la UN el plan está vigente desde 2008, tuvo reajustes entre 2010-2013, mientras que en la UBA es el mismo plan de estudios desde que se creó la carrera en 1984, aunque actualmente hay un proyecto de revisión desde agosto de 2014, que se pretende esté listo para este año 2016.

Los objetivos actuales de la carrera en la UN, hacen énfasis a lo investigativo, mencionando lo ético como algo inherente a las actividades del egresado de DG, su accionar en función de las necesidades de la sociedad, contribuyendo a la construcción y enriquecimiento de la identidad cultural.

En la UBA resaltan el sentido nacional y democrático de la universidad en Argentina y el carácter proyectual de la disciplina sin dejar de lado la idea de estructurar un enfoque metodológico teórico-práctico integrador y la de establecer un diálogo permanente y dinámico con el alumnado, tendiente al enriquecimiento constante de la profesión y al cultivo en el estudiante de una conciencia crítica y reflexiva. (Mazzeo, 2014)

En los dos casos, se reconoce el uso del taller como la metodología pedagógica elegida para las asignaturas prácticas, debido a que es el espacio donde se trabaja de modo semejante a como se haría en una práctica profesional real. Por su lado, para las teóricas se emplea la modalidad tradicional de enseñanza de exposición por parte del profesor.

Se destaca la ausencia de la instancia de trabajo de grado o tesis en la UBA, egresando a los alumnos con el término de las asignaturas que componen el programa de estudios. En la UN

28. Ver infografías \#4 y \#5. 
existe el trabajo de grado como tramo final de la carrera, teniendo tres modalidades posibles para realizarlo: Trabajo proyecto de investigacion-creación; práctica de extensión, práctica profesional o pasantía; asignaturas de posgrado (Cursar asignaturas o el primer semestre de un programa de posgrado).

Como actividades contextuales, en la UN cuentan con programas como los Semilleros de Investigación en Fotografía, Historia y Teoría del DG en Colombia e Ilustración, y espacios encaminados a mostrar el trabajo de los y las estudiantes, como el Salón de Diseño Gráfico, Diseño deMuestra, Muestra de TG, etc. Existen también pasantías o prácticas con empresas como opción al Trabajo de Grado.

La UBA en años recientes (2014-2015) ha organizado la Bienal de Diseño UBA FADU, junto con organismos como el Ministerio de Educación de la Nación, la Red DiSUR (Red de carreras de Diseño en universidades públicas latinoamericanas), el CMD (Centro Metropolitano de Diseño) y el Gobierno de la Ciudad de Buenos Aires, destacándose por ser uno de los eventos más importantes en el ámbito del diseño en Latinoamérica. Con diversas actividades, workshops, charlas, exposiciones y premiaciones, convoca a docentes, alumnos, egresados y personalidades del Diseño en general (gráfico, indumentaria, industrial, imagen y sonido) y a cualquier persona interesada en asistir, a participar activa y abiertamente de todo el evento, el cual es totalmente gratuito. Pretende consolidarse como un suceso cultural, artístico, político y social que trascienda las fronteras de lo académico. (Facultad de Arquitectura y Urbanismo, UBA)

Es de resaltar que la versión 2015, la segunda edición de la bienal, centró sus objetivos en mostrar el cambio perceptual en el ámbito social que según la FADU, desde el Diseño se ha instalado. Considerando que en la actualidad es necesario agudizar no sólo la percepción sobre el Diseño sino pensarlo como motor de cambios y mejoras sociales, es así como se propusieron diferentes ejes temáticos: Industrias nacionales, Cultura Urbana, Política, Inclusión y Sustentabilidad. (Facultad de Arquitectura y Urbanismo, UBA) 


\section{PLAN CURRICULAR 2014 | 2015}

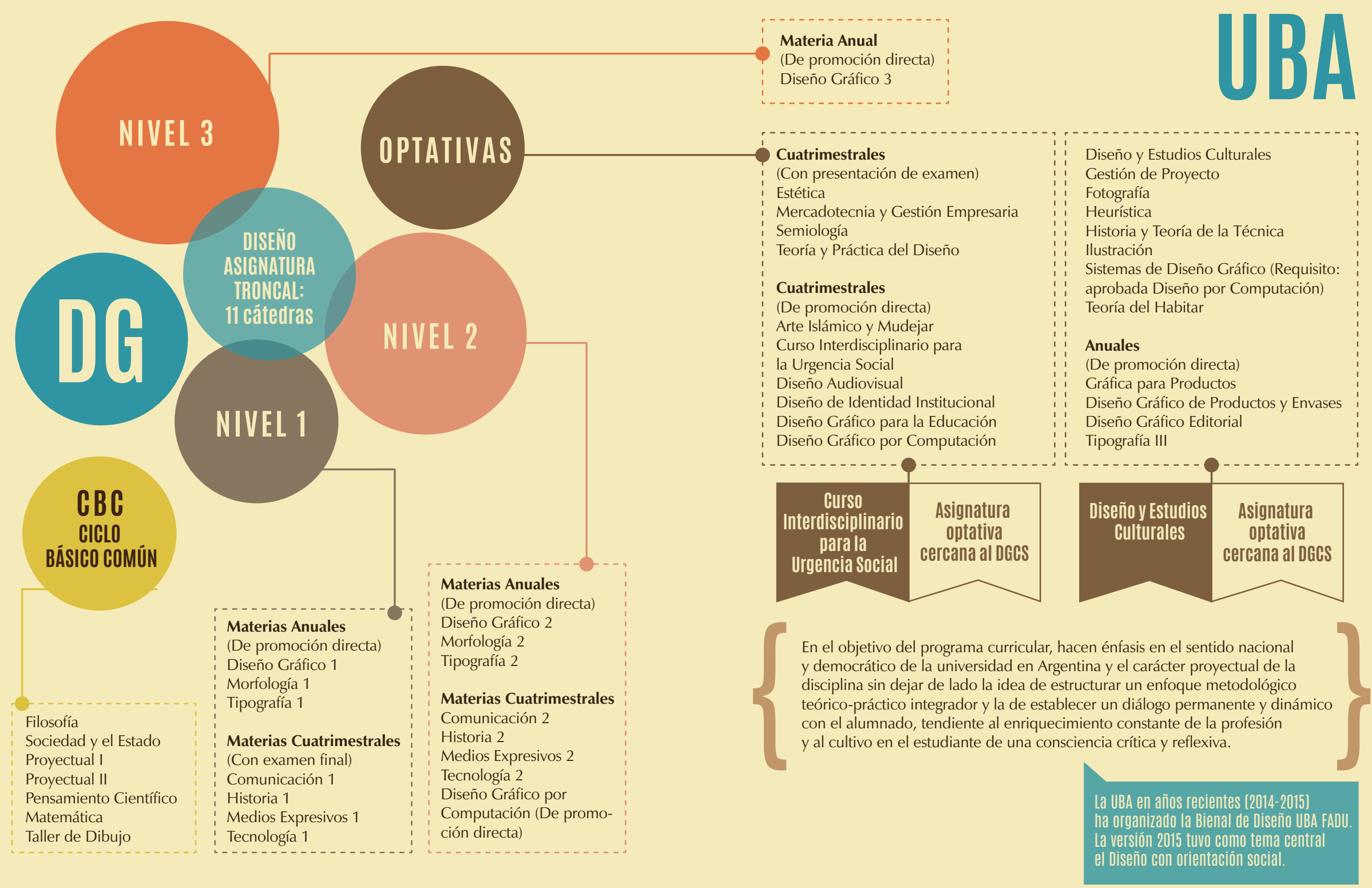




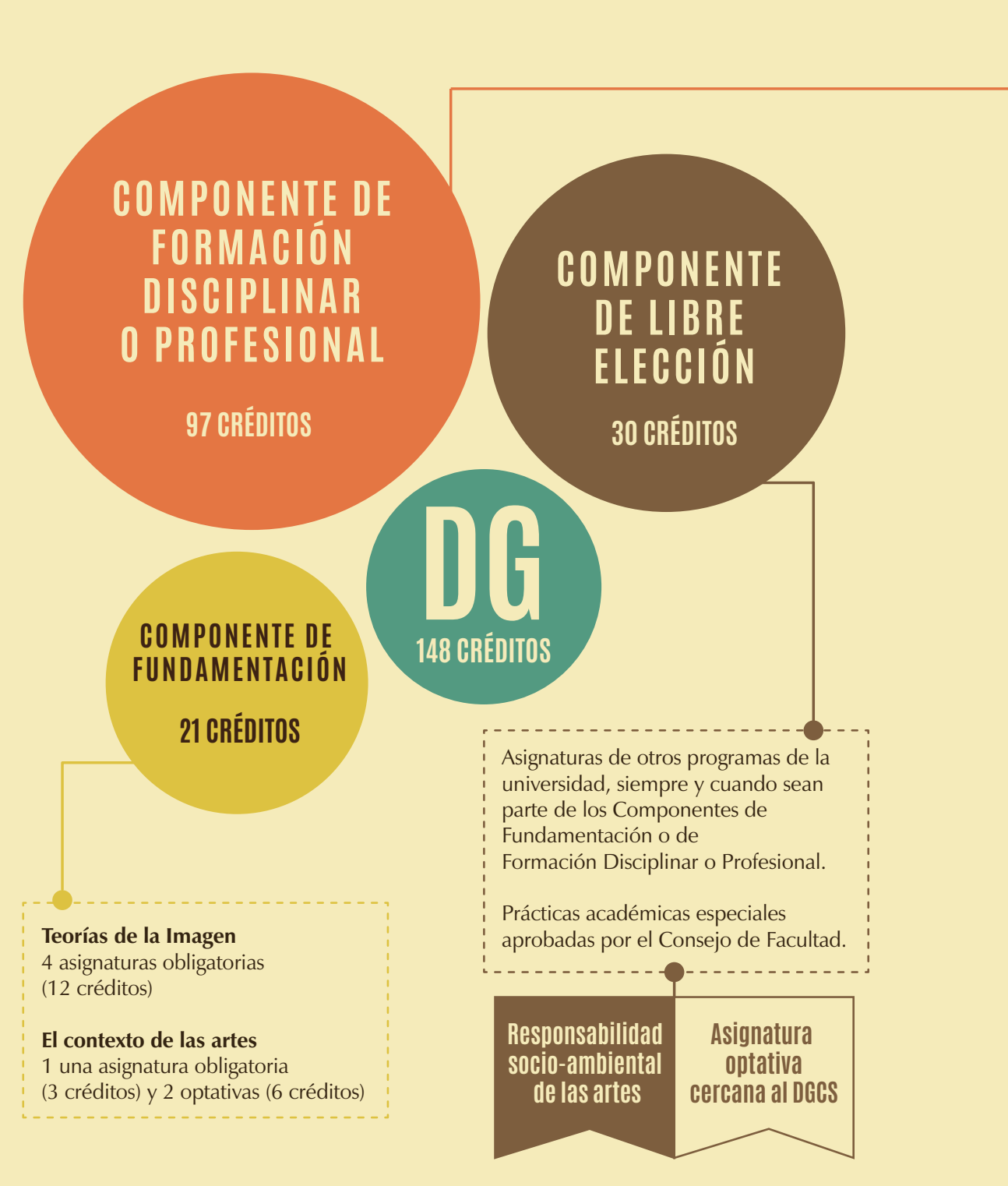

Talleres de diseño

5 asignaturas obligatorias (25 créditos)

Medios de representación

6 asignaturas obligatorias (16 créditos)

Imagen fotográfica

3 asignaturas obligatorias (9 créditos)

Medios de producción

7 asignaturas obligatorias (14 créditos)

Historia y teoría del diseño gráfico

5 asignaturas obligatorias (21 créditos)

Gestión eultural
y empresarial
de las artes $\begin{gathered}\text { Ablignatura } \\ \text { cercana al DGes }\end{gathered}$

Talleres de énfasis

2 asignaturas optativas (6 créditos)

Énfasis en teoría, historia y estética

Énfasis en tipografía y diagramación

Énfasis en multimedia e imagen digital

Énfasis en imagen fotográfica

Énfasis en ilustración

Énfasis en narrativas audiovisuales

Trabajo de grado (6 créditos)

Trabajos investigativos

Prácticas de extensión (pasantías)

Opción de grado (materias de posgrado)
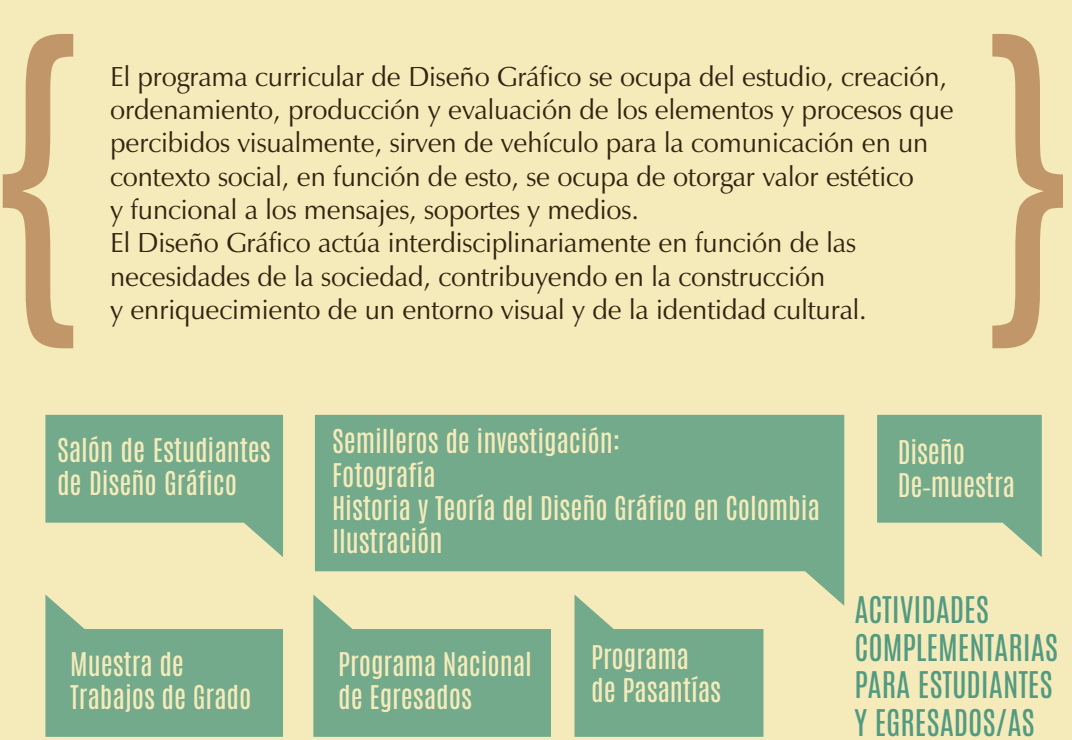

El programa curricular de Diseño Gráfico se ocupa del estudio, creación, ordenamiento, producción y evaluación de los elementos y procesos que percibidos visualmente, sirven de vehículo para la comunicación en un y funcional a los mensajes, soportes y medios.

El Diseño Gráfico actúa interdisciplinariamente en función de las enriqueci le la sociedad, contribuyendo en la construcción

Teorías de la Image (12 créditos)

contexto de las arte

una asignatura obligatoria

créditos) y 2 optativas (6 créditos)
Asignaturas de otros programas de la

Prácticas académicas especiales

aprobadas por el Consejo de Facultad.

\begin{tabular}{cc|}
$\begin{array}{c}\text { Responsabilidad } \\
\text { socio-ambiental } \\
\text { de las artes }\end{array}$ & $\begin{array}{c}\text { Asignatura } \\
\text { optativa } \\
\text { cercana al DGCS }\end{array}$ \\
\hline
\end{tabular}

Salón de Estudiantes

de Diseño Gráfico

Thastra de

de Egresados 
En cada plan curricular pude detectar la presencia de algunas asignaturas cuyo nombre y contenido atraviesan el tema del Diseño con Consciencia Social. Me parece interesante destacarlas, aunque aclaro que desde mi punto de vista, la problematización planteada en esta tesis no pasa únicamente por el contenido de una u otra asignatura, sino que se trata de la estructura de la carrera como tal, de su esencia y del sentido que esta le da al diseño.

\section{Como menciona el profesor Fredy Chaparro ${ }^{29}$ :}

"Más que como una asignatura, (este tema) debe ser involucrado estratégicamente en buena parte de los talleres y algunas asignaturas teóricas, igualmente promover que se desarrollen trabajos de grado. (...) Destaco las experiencias de caso que se han desarrollado en el Taller de Orientación y diseño de información, que ha dispuesto como estrategia temáticas asociadas con comunidades y entornos sociales. Sin embargo la orientación de proyectos orientados a la comunidad no es lo más característico de las asignaturas del programa, pues persiste la metodología de trabajo orientado a la producción de obra gráfica autónoma". ${ }^{30}$

En la carrera ofrecida en la UN existen dos asignaturas optativas que me interesa resaltar. La primera es Responsabilidad socioambiental de las artes, la cual es ofrecida por la Escuela de Diseño Industrial, es abierta a cualquier carrera de la Facultad de Artes y tiene una intensidad de 3 horas por semana que se cursan durante un semestre.

En la información de los contenidos publicada en la web de la UN, dice que pretende introducir y concientizar a los jóvenes de la importancia de su participación como ciudadanos y como profesionales, en el mejoramiento de la calidad de vida para el mañana, en el marco de la sostenibilidad ambiental y social. Tiene como objetivo principal introducir a el/la estudiante de la

29. Diseñador gráfico colombiano egresado en 1987 de la UN. Profesor de tiempo completo de la carrera de Diseño Gráfico con 28 años de experiencia, fue Director de Carrera y Secretario de Facultad de Artes en diferentes periodos. Magíster en Teoría e Historia de la Universidad Nacional de Colombia (2014).

30. Entrevista realizada vía mail al profesor de la UN Fredy Chaparro, el día 9 de junio de 2015. 
Facultad de Artes en la temática ambiental y concientizarlo de la responsabilidad que tiene con el entorno natural y cultural, antes, durante y posterior al desarrollo de sus actividades como futuro profesional y como habitante del planeta tierra. El curso también busca de manera irrestricta evidenciar como las prácticas artísticas y sus profesionales poseen de manera implícita una responsabilidad social que en el entorno de la Universidad Nacional de Colombia se hace más evidente y evidenciable.

La asignatura debe responder las siguientes preguntas:

¿Qué es el Medio Ambiente?

¿Qué es la sostenibilidad?

¿Cuál es el panorama ambiental del país?

¿Qué relación tienen las Artes con el medio ambiente y el desarrollo sostenible?

¿Que es responsabilidad social?

¿Qué responsabilidad desde el hacer, el deber ser y quehacer, tienen los artistas con la sociedad?

¿Desde que escenarios el artista de la Universidad Nacional de Colombia tiene implicaciones de responsabilidad social.

¿Qué responsabilidad tenemos y que se entiende por movilidad urbana sostenible?

(Facultad de Artes - Universidad Nacional de Colombia)

De la asignatura Gestión cultural y empresarial de las artes, aunque no centra sus contenidos en el DGCS, me resulta interesante su carácter de obligatoria y que en su descripción habla de la situación de asumir la cultura como campo ampliado que atiende a la produccion material y simbólica de una sociedad y de manera específica, cuando interroga a los colectivos sociales en cuanto sus rasgos identitarios, referentes materiales, intelectuales e incluso al mundo sensible de un grupo humano: creencias y valores que configuran un rico panorama. En sus contenidos tratan temas sobre legislación cultural, derechos de autor, políticas públicas, 
gestión y apoyo de organismos internacionales. (Facultad de Artes Universidad Nacional de Colombia)

En DG en la UBA, encontré dos asignaturas también de carácter electivo que desde diferentes puntos toman el DGSC como tema de estudio, aunque esto no esté aclarado como tal en sus contenidos.

El Curso Interdisciplinario para la Urgencia Social es una materia electiva cuatrimestral con créditos académicos, dirigida a alumnos avanzados de las seis carreras de la FADU (Diseño Industrial, Diseño de Indumentaria, Diseño de Paisajes, Diseño de Imagen y Sonido, Diseño Gráfico y Arquitectura). La cursan además, alumnos de carreras afines al Diseño y la Arquitectura, provenientes de convenios de intercambio con Universidades Latinoamericanas y de Europa, así como también, alumnos de FLACSO. Está abierta también a voluntarios/as estudiantes o profesionales de otras áreas del conocimiento.

Tiene como objetivo desarrollar la capacidad de abordar proyectos interdisciplinarios que respondan a necesidades reales de comunidades vulnerables y organizaciones solidarias, ejercitar el diseño al límite con escasos o nulos recursos presupuestarios y potenciar, así, aprendizajes y sensibilidad social. (Seminario Interdisciplinario para la Urgencia Social)

Diseño y Estudios Culturales es una materia electiva que se cursa en el último año de las carreras de Diseño Gráfico y Diseño de Indumentaria y Textil. Desarrolla bajo el marco de los Estudios Culturales reflexiones sobre los procesos de producción, circulación y consumo del Diseño y sus transformaciones en las últimas décadas. El enfoque elegido puede leerse como un intento por hacer converger diferentes tradiciones disciplinarias (antropología, sociología, semiótica, historia social, historia de las ideas) en vistas a la construcción de nuevos objetos de estudio y análisis. En nuestro caso, la inclusión de esta perspectiva posibilita una lectura crítica del Diseño que lo interprete a la luz de una constelación de disciplinas y saberes, permitiendo sortear las dificultades que conlleva una lectura unidireccional del Diseño como práctica y disciplina (Diseño y Tecnología/ Diseño y Estética/ Diseño y Sociología, entre otras). 
Los conceptos tratados en la asignatura permiten dar cuenta de la emergencia histórica del Diseño como disciplina y profesión, y detenerse reflexivamente sobre sus actuales problemáticas que involucran mandatos mercantiles, profesionales, éticos y proyectuales. (Diseño y Estudios Culturales)

Aunque en las dos universidades el tema directo de la consciencia y responsabilidad se aborda en asignaturas optativas que aparecen de alguna manera como casos aislados dentro del plan curricular, ya que no forman parte del plan obligatorio de estudios, considero que marcan una presencia destacable e interesante aunque sus planteamientos no partan directamente desde el diseño gráfico.

De entrevistas con egresados de diferentes períodos de la carrera en la UN, pude concluir que en general se tiene la percepción de que es necesario reforzar el concepto de la responsabilidad de el/la profesional del DG como operador/a cultural desde la universidad, mencionan que conocen poco sobre el diseño con consciencia social, y que lo que saben ha sido porque lo vieron en libros, lo escucharon en conferencias o lo encontraron en alguna red social, ya que también existe la idea de que es un tema que ha ido tomando fuerza en los últimos años y se ha difundido bastante a través de internet.

Un egresado de la UN (2001) considera:

"Más que una corriente de diseño, o intentar etiquetarlo para separarlo de lo meramente comercial, la conciencia social es una función intrínseca del diseño. Aportar a procesos de comunicación que permitan reflexionar acerca de problemáticas sociales va ligado al proceso comunicativo, solo es cuestión de enfoque. No se trata de algo que se enseñe como una cátedra en las aulas, esa función del diseño se descubre por si misma al conocer el potencial de la comunicación visual y la fuerza del mensaje gráfico" ${ }^{\prime \prime 1}$.

31. Respuesta obtenida de entrevistas anónimas a egresados de la carrera de Diseño Gráfico de la Universidad Nacional de Colombia y la Universidad de Buenos Aires, realizadas a través de internet en junio de 2015. 
En la UBA encontré una presencia más concreta de lo significa el DGCS desde el planteamiento de esta tesis, ya que en la mayoría de las cátedras los docentes presentan una estructura y contenidos que implícitamente transmiten a los y las estudiantes la consciencia y responsabilidad de su profesión, la esencia misma de lo que es y ha sido la carrera de Diseño Gráfico en esta universidad ubica a los alumnos en una postura crítica frente a lo que están aprendiendo. De hecho, muchos de los docentes han producido y producen materiales teóricos que sirven de referencia y son origen de diversos debates y planteamientos académicos a lo largo de toda América Latina.

Esta esencia crítica puede deberse a los antecedentes históricos de Argentina, atravesada por momentos políticos coyunturales para el país que sucedieron por misma la época de creación de la carrera.

Además, la masividad de alumnos que asisten a esta carrera, en promedio tres mil por cuatrimestre, favoreció la creación de la multiplicidad de cátedras y de ahí las diferentes propuestas basadas en las diversas concepciones de la disciplina desarrolladas en cada una desde el equipo docente, que aunque mantienen líneas definidas, en su mayoría comparten esa posición reflexiva y crítica frente al ser profesional, considero que como consecuencia de ver y apropiarse del Diseño Gráfico como un saber, no como un oficio.

Una característica particular de la carrera en la UBA es la red que se armó en torno a las cátedras, a través de docentes que inicialmente asistieron a las mismas como alumnos, luego como profesores adjuntos o ayudantes, y finalmente como directores de cátedra.

"Estos vínculos cuasi parentales -por cuanto incluyen de forma más o menos directa la totalidad de las cátedras actualmente activas y se establecen vínculos particulares entre todas ellas- constituyen una característica singular que determina las relaciones entre los profesores que integran el área de Diseño y las que se producen entre las diferentes propuestas de enseñanza hoy vigentes". (Mazzeo, 2014) 
Esas diferentes concepciones de disciplina y enseñanza, sus puntos en común y sus diferencias, la prularidad existente, aparece como una especie de oferta democrática para el/la estudiante, quien tiene la total libertad de elegir en el transcurso de la carrera, lo cual sentará las bases de la propia concepción que se forme del sentido de su profesión a partir de allí.

Un/a estudiante de último año de la carrera en la UBA menciona sobre la presencia del DGCS que percibe allí:

"Depende mucho de cada cátedra. Hay varias que tienen una clara inclinación hacia lo social y otras que directamente lo ignoran o son funcionales a las demandas del mercado. No veo mal que en una universidad privada se priorice esa mirada, pero considero que en toda universidad pública se debería fomentar una formación orientada a lo social que forme profesionales responsables y comprometidos con su entorno" ${ }^{\prime \prime 2}$.

En la UN la magnitud de estudiantes y en consecuencia de la oferta académica es mucho menor. Allí ingresan a la carrera en promedio 25 estudiantes por semestre, después de haber pasado la instancia de examen de admisión a la universidad.

Es por ello que los alumnos cuentan con una sola línea de aprendizaje determinada por el programa de estudios, si bien generalmente los/las estudiantes se dividen en dos grupos, se hace por practicidad en los espacios y horarios, no determinado por una u otra concepción de la disciplina. En la formación de la UNAL no hay diversidad de opciones de miradas para los/las estudiantes, la mirada es una sola y es la planteada por la carrera, más allá de que cada profesor tenga sus propios pensamientos y si le interesa se los comunique a sus estudiantes.

En la UN no existe oferta diferenciada de asignaturas, sino que se sigue el plan curricular obligatorio y paralelamente los/las estudiantes tienen la posibilidad de completar sus conocimientos

32. Respuesta obtenida de entrevistas anónimas a estudiantes de la carrera de Diseño Gráfico de la Universidad Nacional de Colombia y la Universidad de Buenos Aires, realizadas a través de internet en junio de 2015 . 
eligiendo las optativas que más se ajusten a sus intereses, igualmente sucede con los Talleres de Énfasis, los cuales establecen diferentes caminos de especialización dentro del Diseño Gráfico: Teoría, historia y estética; Tipografía y diagramación; Multimedia e imagen digital; Imagen fotográfica; Ilustración; Narrativas audiovisuales.

En mi experiencia como estudiante de la UN destaco como positiva la diversidad de opciones de profundización que ahora se ofrece, ya que cuando cursé la carrera (1997-2002) no existía esta posibilidad estructurada, sino que cada uno armaba sus asignaturas electivas como mejor pudiera hacerlo dentro de la oferta existente. $Y$ dentro de estas opciones considero relevante la existencia del taller de énfasis en Teoría, Historia y Estética, lo cual da cuenta del interés de la carrera de conservar el enfoque analítico y reflexivo sobre la profesión.

El profesor Fredy Chaparro menciona que para él la responsabilidad y consciencia sobre la profesión es un tema importante para que sea considerado en la academia, ya que hasta ahora ha estado lejano.

“Con mayor razón el caso de la Nacional que se supone que por su naturaleza pública y sus imaginarios políticos, debería tener una consideración particular y estar explicitamente enunciada, como lineamiento para la orientación de las asignaturas del programa, en particular los talleres de énfasis, algunas teóricas y trabajos de grado. Se han dado casos, pero como bien lo mencionas en el documento (refiriéndose al plan de esta tesis), tienen que ver con enfoques de algunos docentes y experiencias un tanto coyunturales. Creo que el que sean tan politicamente sesgadas es lo que ha impedido que prosperen. Esto ciertamente es una complicación para que el proyecto avance". ${ }^{33}$

De lo que muestra el plan curricular y lo que pude obtener de las entrevistas de los actores involucrados (Estudiantes, egresados y docentes), más allá de que yo misma me formé en

33. Entrevista realizada vía mail al profesor Fredy Chaparro el día 16 de junio de 2015. 
REDISEÑANDO MUNDOS

esta universidad, considero que en la carrera de DG en la UN existe esta consciencia disciplinar por antecedentes históricos que han dejado huella en ella, pero me parece que hace falta volver a ellos y retomar con mayor fuerza este sentido. 



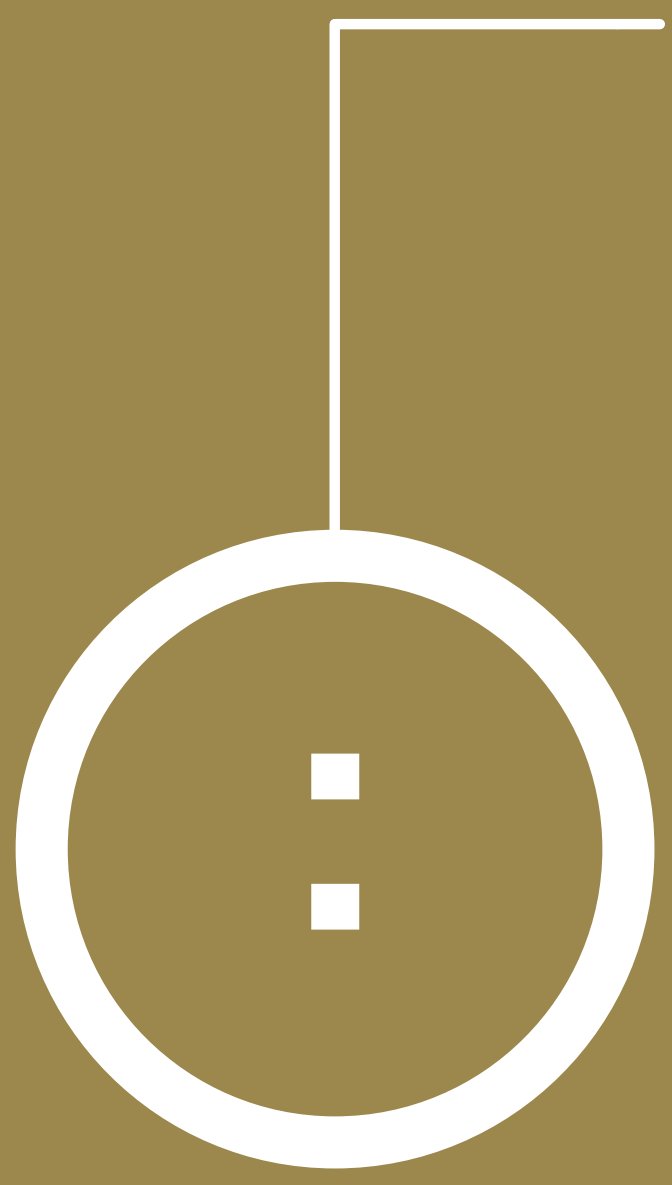




\section{MI PLANIEAMIENTO, \\ MI CONGLUSIÓN}

La maestría PLANGESCO hizo que cambiara mi punto de vista hacia diferentes situaciones de mi vida y principalmente de mi profesión. Cuando empecé tenía una idea totalmente diferente de lo que debe ser y cómo trabajar en Diseño Gráfico, e incluso llegué con un proyecto inicial de tesis que iba enfocado de una manera muy distinta a como resultó finalmente.

Siempre supe que mi tesis debía ir encaminada a mi profesión como diseñadora gráfica y cuando gracias a la maestría descubrí lo que me inquietaba, pude ver aspectos que no sabía que existían en ella. Mi mirada se transformó y a partir de ello me propuse indagar a cerca de un aspecto que hasta ese momento era desconocido para mí: la llamada función social del diseño gráfico.

En el desarrollo de mi investigación entendí que esa "función social" ha estado interpretada a mi parecer de manera equívoca, porque por un lado el Diseño Gráfico en esencia ya cumple funciones sociales, ya sus objetivos van aplicados a sociedades y a personas, independientemente de si lo hacen en el marco del mercado tradicional o no; y por otro lado, se queda corta si se habla de "función social" como esa labor en favor de grupos minoritarios, ONGs, asociaciones civiles, cooperativas y en general grupos que trabajan fuera del mercado capitalista tradicional y sin ánimo de lucro. 
Entendí que el Diseño Gráfico debería concebirse como un todo, debería pensarse como una profesión que desde la comunicación crea cultura y desde allí los/as profesionales del diseño tenemos una responsabilidad frente a nuestro trabajo con la forma y también con el contenido. La función no es solo social, es política, democrática y cultural; y el reto es aprender a cumplir esas funciones dentro del mercado económico en el cual se mueve el ser humano.

Este planteamiento tiene que ver con la mirada de el/ la diseñador/a frente a su profesión, no con una especialidad o enfoque del diseño gráfico. La consciencia de ser diseñador/a pasa por todas las vertientes, desde la forma hasta el contenido y la responsabilidad que tiene sobre lo que comunica y transmite con su trabajo. Y todo ello parte del compromiso de la universidad pública como institución formadora, desde donde el/la diseñador/a profesional tendría que tomar consciencia de su ser político, reconociendo esa característica en sí mismo como ser humano y profesional. La ignorancia de ese estado no lo anula.

Por experiencia sé que hay muchos/as diseñadores y diseñadoras que desde la formación son ajenos/as a esa responsabilidad, porque entendieron su función como algo puramente formal, donde deben preocuparse por organizar los elementos gráficos correctamente según ciertas reglas visuales, sin tener que leer o enterarse siquiera de los contenidos que están diagramando.

En mi recorrido de investigación encontré varias posiciones que asumen los/as diseñadores/as como profesionales, más allá de que cada sujeto maneje el concepto de ética como persona y dentro de ello tenga niveles de comportamiento. Una se da cuando el/la diseñador/a considera que no necesariamente debe compartir la ideología de su cliente, lo cual lo/a libera para trabajar con quien sea que convoque. Otra es la de el/la diseñador/a que se siente responsable de los contenidos a los cuales él le está dando forma y por ello sí se compromete ideológicamente con su trabajo. Y la tercera sería la de aquellos/as profesionales que aún no son conscientes de su condición de sujetos políticos y por ello trabajan en el día a día sin reflexionar sobre lo que están produciendo. 
En cualquier caso, todo proyecto gráfico tiene consecuencias. Ningún símbolo es neutro (Kaplún, 1998), las imágenes no son inocentes.

"Somos producto de una educación, de una sociedad que nos ha formado; hablamos un lenguaje que lleva implícitas significaciones y connotaciones; llevamos grabados dentro de nosotros una serie de estereotipos, de clichés mentales. A menos que sepamos leer críticamente nuestros propios mensajes, todo ese código que está en nuestro subconsciente se nos disparará automáticamente al realizarlos y podemos terminar reforzando los patrones culturales que el destinatario ha interiorizado, en lugar de contribuir a cuestionarlos". (Kaplún, 1998)

Toda persona es política y tiene responsabilidad sobre las consecuencias de lo que hace, profesionales o no de ciertas disciplinas, sin embargo hay quienes no son conscientes de ello o directamente consideran que no son responsables sobre lo que su trabajo genere en el planeta. En este caso, el/la diseñador/a en tanto comunicador/a, en tanto operador/a cultural, tiene una responsabilidad mayor porque en sus manos tiene la posibilidad de difundir pensamientos a grandes grupos de personas, no con la intención de persuadir, sino de concientizar, para hacer que el otro reflexione y critique. El/la profesional del diseño transforma el mundo cultural.

“El diseñador es un mediador entre el público al que se dirige y el cliente o el impulsor del proyecto. Y su responsabilidad final es ante el público destinatario. Por eso insisto en que el diseñador es el abogado del público ante su cliente y el valedor del proyecto ante el público. La ética del diseñador consiste en la libertad de rechazar un proyecto cuyo objetivo no esté de acuerdo con sus principios personales". (Costa, 2014)

La consciencia social de el/la diseñador/a gráfico/a es darse cuenta de la responsabilidad sobre las consecuencias de lo que produce su trabajo.

No es mi intención cuestionar la ausencia de esta perspectiva directa en la enseñanza del DG en las universidades elegidas como casos de estudio en esta tesis, si de hecho la historia y la definición 
misma de la profesión dan cuenta de cómo se le ha dado más relevancia al producto y no al proceso.

El diseño gráfico puede abordarse como oficio o como saber. En esta tesis hice el descubrimiento personal a partir de los estudios de Verónica Devalle, de que la manera de historizar el diseño a partir de relatar la historia de los objetos producidos por el mismo, es una de las principales causas de que aún hoy en día siga primando el objeto sobre el proceso y de que el objetivo final de la práctica del DG sea la meta y no el recorrido. La historia del DG ha sido la historia de los objetos que produce el DG, no de lo que realmente es el DG, por ello si no se considera al DG como parte de la cultura, la misma manera de verlo ligado a la producción de objetos impide mirar lo que para una sociedad significa su práctica.

También sé que no es función de esta tesis juzgar como buena o mala su ausencia. Mi interés se centra en llamar la atención a esa perspectiva que según mi planteamiento podría ser intrínseco al acto mismo de diseñar y no quedarse en una corriente del diseño gráfico.

Si se mira la profesión desde la perspectiva del diálogo, la comunicación sería el proceso natural del diseño para crear sentidos. Dejaría de verse como un oficio instrumental para producir objetos. Y como consecuencia los aspectos democrático, participativo, social y político surgirían inevitablemente.

También es necesario alejarse de los "mesianismos" que a veces se le atribuyen al Diseño Gráfico como salvador del mundo. Todo profesional es responsable sobre las consecuencias de su trabajo sea cual sea su disciplina. Sin embargo en esta tesis resalto la responsabilidad de el/la diseñador/a gráfico/a desde el punto de vista de la comunicación como diálogo para crear sentidos y, desde allí, tener presente que el Diseño antes de persuadir, puede problematizar situaciones en sus receptores. Sí puede ser agente de cambio de realidades, desde quienes toman consciencia de la responsabilidad de su profesión hacia quienes como usuarios o público receptor sienten y ven la necesidad de transformarse. 
En general, los/las estudiantes, egresados/as y docentes entrevistados de la UN y de la UBA, entienden la importancia de comprender la responsabilidad del Diseño como profesión pero no lo ven presente en las aulas directamente. Algunos consideran que es algo que está dado por la formación integral de cada persona y que por ello es un aspecto que no es necesario nombrar con total claridad en la universidad, mientras que otros van más allá y sienten que el contexto universitario es el ideal para promover esa concientización sobre las consecuencias de la disciplina, justo antes de lanzarse al mundo profesional.

Para mí, este re-diseñando mundos va dirigido a los y las estudiantes, a sus realidades, se trata de re-diseñar los propios pensamientos. Por ello me interesa plantear un seminario con el cual proponer un inicio para llenar ese espacio en la academia, en la UN tímidamente presente, en la UBA presente pero a veces no consciente, donde al estudiante se le muestre una mirada directa, posible y real desde la cual puede existir como profesional.

Creo que nada es obvio. Por eso me planteo como algo necesario reflexionar sobre la responsabilidad de la profesión del Diseño Gráfico. Esa responsabilidad no es algo intrínseco a la misma, no es algo natural ni algo que los/las profesionales en general piensen o en lo que concuerden, por lo mismo creo importante generar esa reflexión desde diferentes espacios. Es algo que quise lograr con el desarrollo de esta tesis de maestría, generar un lugar de pensamiento sobre un aspecto que atraviesa la profesión entera y que pocas veces nos detenemos a pensar. 



\section{SEMINARIO UNIVERSITARIO, UNA PROPUESTA}

"Dos espacios privilegiamos para remontar la infantilización: el laboratorio y el seminario. () El seminario resulta todavía un ideal, digamos que está en la antípoda de la estructura tradicional de la cátedra: no venimos al aula solo a escuchar, sino también a participar y a crecer en la interacción. () Semillero, espacio donde interactuan educadores y estudiantes, ámbito de relación entre seres preocupados por un mismo tema. () Un seminario, o es un una unidad de comunicación y de interaprendizaje, o no es nada. Seminarizar las universidades, entonces, colmarlas de semilleros en los cuales todos podamos crecer." (Castillo, La comunicación en la educación, 2011)

Esta es una propuesta de seminario inspirada principalmente en las experiencias de estudiantes y egresados de la carrera de Diseño Gráfico de la Universidad Nacional de Colombia y la Universidad de Buenos Aires y pensada para dirigirse también a estudiantes de esta carrera en otros países de América Latina. La propuesta va encaminada a hacer entender la posición del Diseño Gráfico con Consciencia Social, para descubrir con qué prácticas, en qué lugares y qué experiencias brinda la universidad pública actualmente para que exista esa construcción como sujeto profesional y responsable.

Se trata de un seminario que promueva prácticas de producción de subjetividades políticas en la formación de el/la diseñador/a, alejándose de la idea de mostrar líneas de trabajo $\mathrm{u}$ horizontes profesionales, sino alimentando el concepto de 
construir junto con el otro una problemática que puede ser naturalizada, partiendo de la concientización y descubrimiento propios de cada sujeto.

A continuación presento un acercamiento a la estructura para la construcción de este seminario.

\section{1 ¿A quién va dirigido?}

Este seminario estaría dirigido a estudiantes y/o egresados de diseño gráfico interesados en aprender cómo estar en contacto directo con la sociedad y permanecer conectados con ella y sus necesidades. En entender de esta manera los problemas y emplear el diseño para resolverlos, lejos de la posición aquella de que el/ la diseñador/a es dueño/a del conocimiento y por eso es el único que debe proponer durante el proceso, o la posición opuesta donde se dice que el cliente tiene la razón por ser quien paga el trabajo y el/la diseñador/a olvida su responsabilidad sobre lo que está comunicando y cómo lo está haciendo. Sería un diseño social, pero también político, democrático, participativo, responsable y consciente. Esto significaría una nueva perspectiva y una manera diferente de entender la naturaleza del diseño.

\subsection{Objetivo general}

Problematizar la posición del estudiante como profesional, sin intención de enseñar una fórmula para saber cómo debe comportarse en su profesión, o qué debería o no debería hacer. El objetivo es que el estudiante reflexione sobre la naturaleza de su profesión. Está lejos de querer mostrar al diseño como el salvador. Se trata de volver a pensar en la responsabilidad del diseño, sin el interés de afirmar que es el único responsable, es claro que todas las profesiones tienen cierto grado de responsabilidad en la sociedad, pero no está de más volver a pensar sobre la propia, más cuando ésta tiene la función de comunicar, ese privilegio y responsabilidad de dialogar con muchas personas a la vez y en poco tiempo, no así 
el médico, ni el ingeniero, ni el arquitecto. "Cuando los dos polos del diálogo se ligan así, con amor, con esperanza, con fe el uno en el otro, se hacen críticos en la búsqueda común de algo. Sólo ahí hay comunicación. Sólo el diálogo comunica". (Kaplún, 1998)

El seminario se quiere referir a una responsabilidad que tiene el/la profesional del diseño en el mensaje porque él/ella y su trabajo comunica desde todos lados, desde el material y proceso de producción que elige, hasta la responsabilidad de entender lo que se está comunicando.

El seminario pretende fortalecer la responsabilidad, la solidaridad, el profesionalismo, la creatividad y la consciencia de comunidad, enfocada a la sociedad, a sus necesidades y a sus cambios, lejos del desarrollo de objetos o piezas aisladas sin una función definida, que en últimas no están resolviendo un problema, sino creando uno nuevo. Se trata de aprender a descubrir y entender las necesidades de un grupo o comunidad, no de crear nuevas.

Por fortuna el contexto favorece, como menciona Kaplún:

"Los hombres y los pueblos de hoy se niegan a seguir siendo receptores pasivos y ejecutores de órdenes. Sienten la necesidad y exigen el derecho de participar, de ser actores, protagonistas, en la construcción de la nueva sociedad auténticamente democrática. Así como reclaman justicia, igualdad, el derecho a la salud, el derecho a la educación, etc., reclaman también su derecho a la participación. Y, por tanto, a la comunicación. Definir qué entendemos por comunicación, equivale a decir en qué clase de sociedad queremos vivir". (Kaplún, 1998)

El objetivo es que el sujeto piense y ese pensar lo lleve a transformar su realidad. (Kaplún, 1998)

\subsection{Metodología general}

"No es que el hacer del diseño sea otro, pero la forma de pensarlo si tiene que ser otra, y la forma de enseñarlo también 
tiene q ser otra. No puede seguir siendo como hace 20 años donde el modelo es el profesor, ni lo que dice el profesor es lo que está validado porque no es así. Hoy el profesor dice algo y los alumnos te googlean y tienen 50 cosas distintas para opinar. Lo peor es que no lo hacen. (...) "Y no tiene que ver con el diseño, tiene que ver con el sistema educativo total". ${ }^{34}$

Tomando como una referencia importante el tipo de educación descrito por Mario Kaplún, refiriéndose a Pablo Freire:

"Educación que pone el énfasis en el proceso: destaca la importancia del proceso de transformación de la persona y las comunidades. No se preocupa tanto de los contenidos que van a ser comunicados ni de los efectos en término de comportamiento, cuanto de la interacción dialéctica entre las personas y su realidad; del desarrollo de sus capacidades intelectuales y de su consciencia social". (Kaplún, 1998)

Planteo un seminario que se difunda en las universidades teniendo en cuenta diversos factores, desde el método de enseñanza, pasando por los contenidos, los sistemas de evaluación y una práctica en un contexto social.

Los núcleos claves serían atravesados por una visualización en paralelo del diseño comercial tradicional y las diferentes corrientes del diseño con consciencia social, desde sus antecedentes históricos y cómo han desembocado en la actualidad en múltiples conceptos: diseño social, diseño democrático, diseño sustentable, entre otros. Estarían presentes los aspectos que se han de tener en cuenta en un proceso de Diseño con Consciencia Social: elección de sistemas y materiales, prioridad al ser humano y no al objeto, producción comprometida y consecuente.

Se trabajaría un ordenamiento teórico basado en comunicación, significación, teorías de diseño comunicacional, planificación y gestión de procesos, mediante la modalidad de talleres participativos en donde los/las alumnos/as puedan poner

34. Respuesta obtenida a entrevista con el profesor Daniel Wolkowicz el 19 de julio de 2015. 
en práctica desde el primer encuentro el mismo tipo de relaciones comunicativas que se intentará que descubran con sus propios proyectos de diseño junto con sus colaboradores y/o usuarios.

"Si bien se mira, este modelo también se plantea un «cambio de actitudes»; pero no asociado a la adopción de nuevas tecnologías ni al condicionamiento mecánico de conductas. El cambio fundamental aquí consiste en el paso de un hombre acrítico a un hombre crítico; en ese proceso de un hombre desde los condicionamientos que lo han hecho pasivo, conformista, fatalista, hasta la voluntad de asumir su destino humano; desde las tendencias individualistas y egoístas hasta la apertura a los valores solidarios y comunitarios. Lo que importa aquí, más que enseñar cosas y transmitir contenidos, es que el sujeto aprenda a aprender. El modelo se basa en la participación activa del sujeto en el proceso educativo, y forma para la participación en la sociedad". (Kaplún, 1998)

Tomando también en consideración las palabras de Daniel Prieto Castillo:

“No se construyen conocimientos como quien está haciendo un edificio o algo fuera de sí mismo. Uno construye precisamente en sí mismo. Por lo tanto, en el terreno de la educación, construir es construirse. (...) La transformación solo adquiere algún sentido cuando se apoya en una apropiación de la propia historia personal y en una autovaloración, en la riqueza de las interacciones, en el interaprendizaje, en la proyección segura hacia el mañana. Es esa la comunicación de fundamento. Lo demás, técnicas actorales, recursos audiovisuales, equipos de última generación, redes y mundos virtuales, son solo medios". (Castillo, La comunicación en la educación, 2011)

El seminario articularía puntos de análisis, hallazgos, perspectivas y representaciones del Diseño Gráfico con Consciencia Social, permitiendo a los/las alumnos/as conocer y entender el significado de este enfoque, reflexionar críticamente y realizar aportes y sugerencias al mismo seminario. Se enmarcaría en principio en el contexto latinoamericano para mostrar a los/las estudiantes las múltiples posibilidades de trabajo en conjunto con las sociedades de la región. 





\section{Bibliografía}

\section{Libros y documentos}

Arfuch, L., Chaves, N., \& Ledesma, M. (1997). Diseño y Comunicación. Teorías y enfoques críticos. Buenos Aires: La Crujía.

Barbero, J. M. (22 al 27 de abril de 2002). La globalización en clave cultural: Una mirada latinoamericana. Globalismo y Pluralismo: Coloquio internacional. Montréal, Canadá.

Barrera Jurado, G.E. \& Quiñones Aguilar, A.C. (2009). Diseño Socialmente Responsable. Ideología y Participación. Bogotá: Editorial Pontificia Universidad Javeriana.

Bourdieu, P. (1990). Sociología y Cultura. México, DF: Editorial Grijalbo, S.A.

Castillo, D. P. (1980). Diseño y comunicación. México: Universidad Autónoma Metropolitana-Xochimilco.

Castillo, D. P. (2011). La comunicación EN la educación. Buenos Aires: Ediciones La Crujía.

Chaparro, F. (Octubre de 2012). Enseñar, publicar, exponer. Estrategias para la inserción del diseño gráfico en Colombia. Tesis de Maestría en Historia y Teoría del Arte, la Arquitectura y la Ciudad, Facultad de Artes, Universidad Nacional de Colombia. Bogotá D.C., Cundinamarca, Colombia. 
Clavel, G. P. (1997). Intervención en mesa redonda. 18. (R. tipoGráfica, Entrevistador)

Comité Asesor del Programa Curricular de Diseño Gráfico. (2013). Programa Curricular de Pregrado Diseño Gráfico. Área Curricular Imagen y Creación Artística. PEP Diseño GráficoProyecto Educativo del Programa. Bogotá D.C., Colombia.

Costa, J. (Mayo de 2014). (R. d. Social, Entrevistador)

De Sousa Santos, B. (2011). La Universidad en el siglo XXI. Para una reforma democrática y emancipadora de la universidad. Buenos Aires: Miño y Dávila Editorial.

Devalle, V. (2009). La travesía de la forma. Buenos Aires: Paidós Estudios de Comunicación.

Díaz Giraldo, R. (2006). Poder y resistencia en Michel Foucault. Tabula Rasa Revista de Humanidades, 103-122.

Frascara, J. (1997). Diseño gráfico para la gente. Buenos Aires: Ediciones Infinito.

Frascara, J. (2011). El diseño de comunicación. Buenos Aires: Ediciones Infinito.

Kaplún, M. (1998). Una pedagogía de la comunicación. Madrid: Ediciones De La Torre.

Ledesma, M. (2010). El diseño gráfico, una voz pública. Buenos Aires: Wolcowickz Editores.

Manual Sembrando mi tierra del futuro. $2^{\circ}$ Edición. (2011). La Plata, Buenos Aires: Unidad de Tesis y Producción de Conocimiento. Facultad de Periodismo. Universidad Nacional de La Plata.

Mazzeo, C. (2014). ¿Qué dice del diseño de la enseñanza del diseño? Buenos Aires: Ediciones Infinito. 
Meggs, P. (2000). Historia del diseño gráfico. México: Editorial Mcgraw-Hill / Interamericana de México.

Papanek, V. J. (1984 ). Design for the Real World: Human Ecology and Social Change. Chicago: Academy Chicago.

Revista tipoGráfica. Comunicación para diseñadores. Revista de diseño, año XI, n 33 (1997). Buenos Aires: AGI.

Romero, J. L. (1967). Latinoamérica: Situaciones e ideologías. Buenos Aires: Ediciones del Candil.

Torrico, E. (2010). La Comunicología de Liberación, otra fuente para el pensamiento decolonial. Una aproximación a las ideas de Luis Ramiro Beltrán. Quórum Académico. Universidad del Zulia. Maracaibo. Vol. 7, no 1, 65-77.

Villamayor, C. (2006). La comunicación como perspectiva y como dimensión de los procesos sociales. Una experiencia de participación en las Políticas Públicas. PSA FORMOSA. UNIrevista, Vol. $1, n^{\circ} 3$.

\section{Referencias en internet}

AIGA. (s.f.). Design for good. Recuperado el enero de 2015, de http://designforgoodwm.com/

Bienestar Sede Bogotá. (s.f.). Obtenido de http://www.bienestarbogota.unal.edu.co/egresados.php

Botina, V. H. (23 de mayo de 2012). ForoAlfa.

Recuperado el 22 de noviembre de 2012, de ForoAlfa: www.foroalfa.org

Brea, G. (2005). Foro Alfa. Recuperado el 2015, de http://www.foroalfa.org 
Costa, J. (27 de Noviembre de 2012). ForoAlfa.

Recuperado el 27 de Noviembre de 2012,

de ForoAlfa: www.foroalfa.org

Creatividad Ética. (s.f.). Creatividad Ética.

Recuperado el enero de 2015, de http://www.creatividadetica.org/

Design Thinking en Español. (s.f.). Obtenido de http://www.designthinking.es/aprende/index.php

Design Thinks. (s.f.). Recuperado el enero de 2016, de http://designthinks.blogspot.com.ar/2009/01/grapus.html

Diseño Social En+. (s.f.). Recuperado el enero de 2015, de www.disenosocial.org

Diseño y Estudios Culturales. (s.f.). Recuperado el Diciembre de 2015, de https://dyec.wordpress.com/presentacion/

Encuentro de Políticas Públicas y Diseños. (2010).

Encuentro de Políticas Públicas y Diseños. Recuperado el 2015, de http://encuentropoliticaydisenos.wordpress.com

Encuentros Políticas Públicas y Diseños. (2014).

Encuentros Políticas Públicas y Diseños. Recuperado el 2015, de https://encuentropoliticaydisenos.wordpress.com/

Facultad de Arquitectura y Urbanismo, UBA. (s.f.).

Bienal FADU UBA. Recuperado el Diciembre de 2015, de http://www.bienal.fadu.uba.ar/

Facultad de Artes - Universidad Nacional de Colombia. (s.f.). Programas académicos. Recuperado el Diciembre de 2015, de http://programasacademicos.unal.edu.co/

Frías, J. (5 de Noviembre de 2012). ForoAlfa. Recuperado el 19 de Noviembre de 2012, de http://foroalfa.org/articulos/laspoliticas-del-diseno-en-latinoamerica 
Frías, J. (s.f.). Foro Alfa. Recuperado el 2014, de Foro Alfa:

http://foroalfa.org/articulos/el-diseno-de-una-politica-de-diseno

Gramsci.org.ar. (s.f.). Recuperado el octubre de 2015, de http://www.gramsci.org.ar/12/gruppi_heg_en_gramsci.htm

Hernández, V. (23 de Mayo de 2012). Foro Alfa. Recuperado el 22 de Noviembre de 2012, de http://www.foroalfa.org

Hoy es el día. (s.f.). Hoy es el día. Recuperado el enero de 2015, de http://www.hoyeseldia.es/

Implicate. (2015). Implicate.org. Recuperado el febrero de 2015, de http://implicate.org

Mackay, M. (2008). Duopixel. Recuperado el abril de 2012, de blog.duopixel.com

Ministerio de Industria, Presidencia de la Nación. (s.f.). Obtenido de http://www.industria.gob.ar/plan-nacional-de-diseno-2/

Pelta, R. (2011). Diseñar para el Cambio Social. Monográfica \#2 / Revista Temática de Diseño. Revista digital.

Pelta, R. (Enero de 2012). Diseño y Activismo. Monografica \# 2 / Revista Temática de Diseño. Revista digital.

Pelta, R. (2012). Manifiesto First Things First 2000. Monográfica \#2 / Revista Temática de Diseño, Revista digital.

Plan Nacional de Diseño. (2012). Recuperado el 2013, de http://www.pnd.gov.ar/desarrollo-regional-2/

Prensa Argentina. (2012). Obtenido de http://www.prensa.argentina.ar/2013/04/16/39927-apruebanbases-y-condiciones-del-programa-sello-de-buendiseno-2013.php 
Red de Diseñadores con Conciencia Social. (s.f.). Red DCS. Recuperado el enero de 2015, de https://www.facebook.com/red.dcsocial

Red de Diseñadores con Consciencia Social. (Marzo de 2014). Foro Alfa. Recuperado el Abril de 2014, de http://foroalfa.org/ articulos/como-iniciarse-en-el-diseno-con-conciencia-social

Regrafica. (s.f.). Regrafica. Recuperado el enero de 2015, de http://regrafica.org

San Francisco Estudio Creativo. (s.f.). Recuperado el Junio de 2015, de http://www.sanfranciscoestudiocreativo.com/

Seminario Interdisciplinario para la Urgencia Social. (s.f.). SIUS. Recuperado el Diciembre de 2015, http://www.sius.com.ar/

The Center for Universal Design. (s.f.). Recuperado el Noviembre de 2014, de http://www.ncsu.edu/ncsu/design/ cud/about_us/usronmace.htm

Tackara, J. (s.f.). The Doors of Perception. Recuperado el febrero de 2015, de http://www.doorsofperception.com/

The Yes Men y otros. (2008). New York Times Special Edition. Recuperado el 2015, de http://www.nytimes-se.com/

UNESCO. (2010). Recuperado el 2012, de http://www.unesco. org/new/es/culture/themes/cultural-diversity/diversityof-cultural-expressions/tools/policy-guide/implementar/abrirmercados-y-crear-publicos/programa-brasileno-de-disenouna-buena-practica/

Vico, M. (2011). Monográfica. Obtenido de El cartel político del gobierno de Salvador Allende (1970-1973): http://www.monografica.org/02/02/Art\%C3\%ADculo/3956

Vico, M. (2012). Monográfica. Obtenido de La lucha es de todos. Movimientos juveniles y cartel en Chile. 



\section{REDISEÑANDO MUNDOS}

Tesis de Maestría

Planificación y Gestión de Procesos Comunicacionales PLANGESCO (Cohorte 2011)

Universidad Nacional de La Plata

Diseño y diagramación: Lucía Sandoval Andrade

Para este documento se usaron las fuentes Zapf Humanst y Antonio.

Sus páginas internas se imprimieron digitalmente sobre papel ecológico producido en Argentina, elaborado con un 90\% de bagazo de caña de azúcar y un $10 \%$ de fibra celulósica maderera certificada (www.eco-comunicacion.com.ar).

Buenos Aires, Argentina, marzo de 2016 
"Yo me peleo con una cátedra que es muy tradicionalista, más del mercado (...).

Él lo dice abiertamente en su propuesta: el diseñador no existe si no hay mercado, el mercado es el que define, si no hay cliente no hay diseño. Entonces cuando él hacia esos pack de electrodomésticos, (...) nosotros estábamos haciendo un pack donde vos tenías que poder llevar un animal vivo desde la veterinaria hasta tu casa y que sobreviviera, el animal lo elegías vos, con lo cual había packs para caracoles, para tiburones, para ovejas, para perros, para gatos, para iguanas, etc.

Entonces me decía: "iVos estás loco haciendo esos pack!", y le digo: "¿Sabés cuál es la diferencia? es posible que esto sea una locura, pero si ellos pueden resolver este pack, hacer el pack de los electrodomésticos va a ser de taquito, ahora los tuyos que hacen todos pack de cajas cuadradas, cuando tengan un problema de supervivencia de un animal que tiene que estar alimentado y que respirar va a ser un nivel de complejidad de un desarrollo mayor... ahí vas a ver qué problema se van a encontrar, y realmente nosotros además de hacerlo funcionar, nos divertimos!".*

*Anécdota compartida por el profesor Daniel Wolkowicz (UBA) en entrevista para esta tesis, el 19 de julio de 2015. 


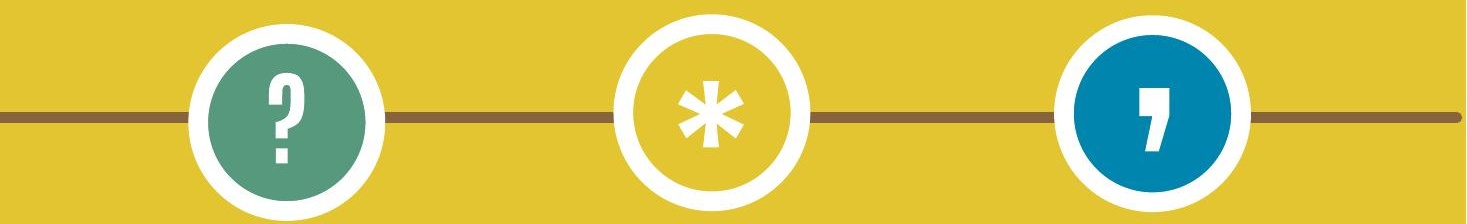

REDISEÑANDO MUNDOS

Tesis de maestría

Planificación y Gestión de Procesos

Comunicacionales - PLANGESCO
Autora: Lucía Sandoval Andrade

Director: Germán Retola

Universidad Nacional de La Plata Argentina, marzo de 2016 